\title{
Was Justice Ginsburg Roe-Ght?: Reimagining U.S. Abortion Discourse in the Wake of Argentina's Marea Verde
}

Kim D. Ricardo

Follow this and additional works at: https://open.mitchellhamline.edu/mhlr

Part of the Constitutional Law Commons

\section{Recommended Citation}

Ricardo, Kim D. (2022) "Was Justice Ginsburg Roe-Ght?: Reimagining U.S. Abortion Discourse in the Wake of Argentina's Marea Verde," Mitchell Hamline Law Review. Vol. 48 : Iss. 1 , Article 4.

Available at: https://open.mitchellhamline.edu/mhlr/vol48/iss1/4

This Article is brought to you for free and open access by the Law Reviews and Journals at Mitchell Hamline Open Access. It has been accepted for inclusion in Mitchell Hamline Law Review by an authorized administrator of Mitchell Hamline Open Access. For more information, please contact sean.felhofer@mitchellhamline.edu. (c) Mitchell Hamline School of Law

$\mathrm{MH}$ MITCHELL | HAMUINE OPEN ACCESS selod of the mitchellhamline.edu 


\title{
WAS JUSTICE GINSBURG ROE-GHT?: REIMAGINING U.S. ABORTION DISCOURSE IN THE WAKE OF ARGENTINA'S MAREA VERDE
}

\author{
Kim D. Ricardo'
}

"[E]n muchos países del mundo, sobre todo los más desarrollados, el aborto es algo que se discutió hace decadas. Nosotros lo estamos discutiendo ahora, atrasadísimos."

I. Prelude. 129

II. Introduction

III. Abortion Rights in the United States
A. Pre-Roe 135
B. Roe v. Wade. 136
C. Post-Roe 139
D. Dobbs v.Jackson Women's Health Organization 141

IV. Reproductive Justice in Argentina . 145
A. Pre-IVE Penal Code Provisions 146
B. Multiple Repertories of Resistance 150

\footnotetext{
' Professor of Law, University of Illinois Chicago School of Law ("UIC Law"). My UIC Law colleagues Sarah Dávila-Ruhaak and Yelena Duterte served as the first readers and interlocutors of this Article; my sincere thanks to them for their dedication to our annual summer writing accountability practice. Many thanks also to the participants of the 2021 Writing as Resistance retreat participants, in particular Sylvia J. Lett, Nantiya Ruan, and Jane Cross for their thoughtful comments and creative ideas for this Article's title. Joelle Juarez provided excellent research support. All errors herein are mine alone. This Article was supported by a Summer 2021 scholarship appointment from UIC Law.

${ }^{2}$ Honorable Cámara de Diputados de la Nación, Diputada Mendoza, Josefina -Sesión 1012-2020 - PL, YOUTUBE (Dec. 10, 2020), https://www.youtube.com/watch?v=gc0IvZ4FXkA [https://perma.cc/4A92-4FLN]. Mendoza is a congressional representative from Buenos Aires. Translated into English, during the 2020 debate on the IVE bill (now Law 27,610, the Voluntary Termination of Pregnancy Law ("IVE Law," for its initials in Spanish)) she observed: "In many countries in the world, in the most developed countries in particular, abortion is something that was debated decades ago. We're doing it today, incredibly late in the game." See also Aborto legal: Diputados dio media sanción al proyecto y ahora define el Senado, Todo Noticias (Dec. 11, 2020) (Arg.), https://n.com.ar/politica/2020/12/10/aborto-legal-el-debate-en-la-camara-de-diputadosminuto-a-minuto/ [https://perma.cc/8QQ8-BV3X] (transcribing Representative Mendoza's speech beginning at 23:13 hours, local time).
} 


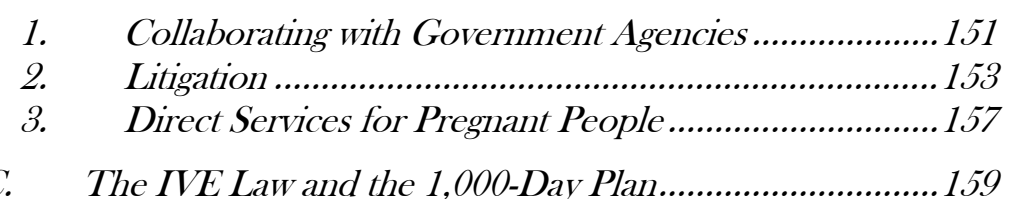

V. Does Argentina Represent the Alternate Reality Contemplated

by Justice Ginsburg? ........................................................................... 161

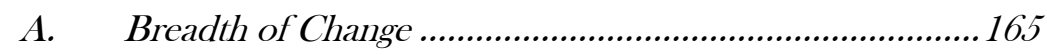

B. Public Awareness........................................................... 168

C. Legitimacy of the Change ................................................ 174

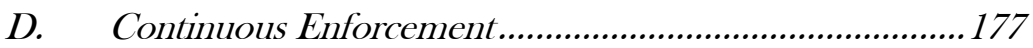

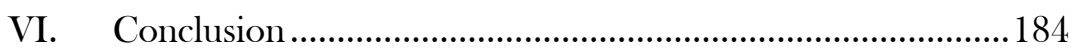

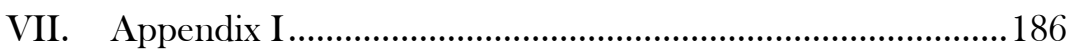

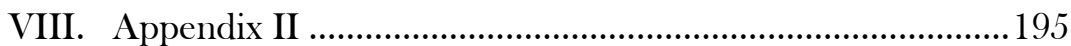

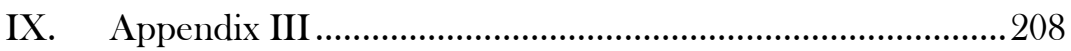

"This Court should overrule Roe and Casey."

--Brief of Petitioners, Dobbs v.Jackson Women's Health Organization (No. 19-1392)

\section{PRELUDE}

On May 17, 2021, the United States Supreme Court granted certiorari in Dobbs v. Jackson Women's Health Organization to address one question: "Whether all pre-viability prohibitions on elective abortions are unconstitutional." ${ }^{4}$ Petitioners in that case explicitly argue that the Court should overrule Roe v. Wade. ${ }^{5}$ Oral arguments took place on December 1, 2021. The Court's ruling is forthcoming.

\section{INTRODUCTION}

${ }^{3}$ Brief for Petitioners at 14, 36, Dobbs v. Jackson Women's Health Org., No. 19-1392 (U.S. July 22, 2021) [hereinafter Petitioners' Brief]. This sentence appears verbatim twice in the Petitioners' Brief.

'Dobbs v. Jackson Women's Health Org., No. 19-1392, 2021 WL 1951792, at *1 (U.S. argued Dec. 1, 2021).

${ }^{5}$ Petitioners' Brief, supra note 3 , at 14, 36. 
Although she died a stalwart progressive icon, ${ }^{6}$ during her 1993 United States Supreme Court confirmation hearings, many liberals were initially skeptical of Ruth Bader Ginsburg's commitment to upholding Roe. The cause for concern originated in comments that then-Circuit Judge Ginsburg made on April 6, 1984, during the William T. Joyner Lecture on Constitutional Law at University of North Carolina School of Law. ${ }^{8}$ Without a doubt, Justice Ginsburg strongly supported the right to abortion, ${ }^{9}$ but even after she was confirmed to the high court, she repeatedly provided critical commentary about the decision in $R_{o e^{10}}$ and the impact it had on the abortion debate in the United States. ${ }^{11}$

${ }^{6}$ Amy Howe, Justice Ruth Bader Ginsburg, Feminist Pioneer and Progressive Icon, Dies at 87, SCOTUSblog (Sept. 18, 2020, 9:26 PM), https://www.scotusblog.com/2020/09/justiceruth-bader-ginsburg-feminist-pioneer-and-progressive-icon-dies-at-87/

[https://perma.cc/E36K-APP4]. Even prior to her death, Justice Ginsburg, a.k.a. RBG, a.k.a. Notorious RBG, became a pop culture icon-the subject of popular biographies, a Hollywood biopic, and an eponymous documentary film. See, e.g., Irin Carmon \& Shana Knizhnik, Notorious RBG: The Life and Times of Ruth Bader GinsburG (2015) (biography); ON THE BASIS OF SEX (Focus Features 2018) (commercial film); RBG (Magnolia Pictures, CNN Films 2018) (documentary film); Heather Elliott, What We Can All Learn from Ruth Bader Ginsburg, Calif. L. Rev. (Jan. 2021), https://www.californialawreview.org/what-we-can-learn-from-rbg/ [https://perma.cc/2XENCQE4].

'See, e.g., Alisha Haridasani Gupta, Why Ruth Bader Ginsburg Wasn't All That Fond of Roe v. Wade, N.Y. Times (May 19, 2020), https://www.nytimes.com/2020/09/21/us/ruthbader-ginsburg-roe-v-wade.html [https://perma.cc/WY2M-Z5R4] (noting that feminist activists were initially suspicious of President Clinton's 1993 nominee to the Supreme Court). ${ }^{8}$ Ruth Bader Ginsburg, Some Thoughts on Autonomy and Equality in Relation to Roe v. Wade, 63 N.C. L. REv. 375, 381 (1985) (opining that the Court "ventured too far" when deciding Roe) [hereinafter Ginsburg, Joyner Lecture].

${ }^{9}$ During her Supreme Court confirmation hearings, Ginsburg unequivocally stated: "The decision whether or not to bear a child is central to a woman's life, to her well-being and dignity. . . . When Government controls that decision for her, she is being treated as less than a fully adult human responsible for her own choices." Nomination of Ruth Bader Ginsburg, to Be Associate Justice of the Supreme Court of the United States: Hearings Before the S. Comm. on the Judiciary, 103rd Cong. 207 (1993) [hereinafter Senate Confirmation Hearing, https:/www.govinfo.gov/content/pkg/GPO-CHRGGINSBURG/pdf/GPO-CHRG-GINSBURG.pdf [https:/perma.cc/55UM-3JH8] (statement of Ruth Bader Ginsburg, nominee to the Supreme Court of the United States).

${ }^{10}$ Roe v. Wade, 410 U.S. 113 (1973).

"See, e.g., Ruth Bader Ginsburg, Speaking in a Judicial Voice, 67 N.Y.U. L. REv. 1185, 1198 (1992) ("Doctrinal limbs too swiftly shaped, experience teaches, may prove unstable. The most prominent example in recent decades is Roe v. Wade." (footnote omitted)) [hereinafter Ginsburg, Madison Lecture]; Meredith Heagney, Justice Ruth Bader Ginsburg Offers Critique of Roe v. Wade During Law School Visit, UnIV. OF CHI. L. Sch. (May 15, 2013), https://www.law.uchicago.edu/news/justice-ruth-bader-ginsburg-offers-critique-roe-vwade-during-law-school-visit [https://perma.cc/2PG6-AQCN] (noting that during a visit to University of Chicago Law School, Ginsburg stated, "My criticism of Roe is that it seemed to have stopped the momentum on the side of change . . ..") (transcript available at https://www.law.uchicago.edu/recordings/justice-ruth-bader-ginsburg-and-geoffrey-stone-roe- 
In her recurring critique of Roe, Justice Ginsburg made two related assertions. First, the Court's decision was based on a flawed legal rationale. Rather than grounding the right to choose an abortion on equality principles as she believed to be more appropriate, ${ }^{12}$ the Court based its decision in a fundamental right to privacy located in the Due Process Clause of the Fourteenth Amendment. ${ }^{13}$ Justice Ginsburg further found fault with the way in which Roe's pronouncements on abortion access privileged the physician's medical expertise over the pregnant person's decision-making capacity standing alone. ${ }^{14}$ Second, Roe invalidated all state laws restricting abortion access prior to the first trimester. ${ }^{15}$ Justice Ginsburg would have struck only the extremely restrictive Texas law in front of the Court at that time. $^{16}$

Justice Ginsburg's critique of Roe was rooted in her studied observation that the Court's ruling had preempted legislative resolutions to the question about reproductive rights and abortion access. She frequently commented that in 1973 (the year that Roe was decided), the public debate about abortion was still in progress and developing-evidenced by the fact that some states had already begun to legislate less restrictive approaches to abortion access. ${ }^{17}$ Justice Ginsburg lamented that the Supreme Court's decision in Roe abruptly declared a legal conclusion to a still very heated

40 [https://perma.cc/JS8C-EWQV]); Jeffrey Rosen, Ruth Bader Ginsburg on the Possibility of Roe v. Wade Being Overturned, Literary Hub (Nov. 11, 2019), https://lithub.com/ruthbader-ginsburg-on-the-possibility-of-roe-v-wade-being-overturned/ [https://perma.cc/QYY223XM] (excerpted from JeFFREY Rosen, CONVERSATIONS WITH RBG (2019)) ("It must start with the people. Legislatures are not going to move without that kind of propulsion.”).

${ }^{12}$ See Ginsburg, Joyner Lecture, supra note 8; see also Senate Confirmation Hearing, supra note 9. In dialogue with Senator Hank Brown, who had asked her about equality and abortion, then-Judge Ginsburg replied: "It is essential to woman's equality with man that she be the decisionmaker, that her choice be controlling. If you impose restraints that impede her choice, you are disadvantaging her because of her sex." Id. at 207.

${ }^{13}$ Roe, 410 U.S. at 164.

"Ginsburg, Joyner Lecture, supra note 8, at 382.

${ }^{15}$ Roe, 410 U.S. at 164.

${ }^{16}$ See Ginsburg, Joyner Lecture, supra note 8, at 380; Ginsburg, Madison Lecture, supra note 11, at 1199; see alsoJustice Ruth Bader Ginsburg and Geoffrey Stone, "Roe at 40" (May 11, 2013) [hereinafter Roe at 40, https://www.law.uchicago.edu/recordings/justice-ruth-baderginsburg-and-geoffrey-stone-roe-40 [https://perma.cc/JS8C-EWQV]; CARMON \& KNIZHNIK, supra note 6 , at $84-85$.

${ }^{17}$ Hawaii became the first state to legalize abortions in 1970, followed soon after by New York, Alaska, and Washington. Only New York, however, did not require in-state residence to obtain an abortion. Julia Jacobs, Remembering an Era Before Roe, When New York Had the 'Most Liberal' Abortion Law, N.Y. Times (July 19, 2018), https://www.nytimes.com/2018/07/19/us/politics/new-york-abortion-roe-wade-nyt.html [https://perma.cc/3R3C-EW77]; Richard Perez-Pena, '70 Abortion Law: New York Said Yes, Stunning the Nation, N.Y. Times (Apr. 9, 2000), https://www.nytimes.com/2000/04/09/nyregion/70-abortion-law-new-york-said-yes-stunningthe-nation.html [https://perma.cc/5MHT-MLBZ]. 
and ongoing social debate. ${ }^{18}$ In its sweeping decision, not only had the Court installed a flawed legal framework for the abortion rights question; in doing so, it had also squelched the development of a broader cultural and social consensus on the divisive topic. ${ }^{19}$

In the aftermath of Roe, the anti-abortion movement galvanized and turned its attention away from piecemeal lobbying efforts in state legislatures to a national litigation strategy with sights trained at the Supreme Court. ${ }^{20}$ Post-Roe, Congress defunded access to abortion through publicly-funded health care, ${ }^{21}$ and subsequent abortion rights cases before the Court have gutted Roe, substantially undermining the right to access abortion. ${ }^{22}$ It is undeniable that post-Roe restrictions have had the greatest impact on the poor, in particular on rural residents and people of color. ${ }^{23}$ In the almost fifty years since Roe, abortion access has become a more-not lesscontroversial issue in the U.S. legal and political landscape. ${ }^{24}$

Implicit in Justice Ginsburg's critique of Roe, however, was her imagining of an alternate reality. What would the political landscape look like without Roe? How would we be speaking about reproductive justice and abortion access in the United States had the social debate run its course through the political process of legislative reform instead of through the Supreme Court's singular pronouncement? The recent victory won by the grassroots reproductive justice movement in Argentina offers us a chance to explore this very thought experiment.

At 4:10 a.m. local time on the penultimate day of 2020-the same year that we lost Justice Ginsburg-the streets surrounding Argentina's Congress were filled with thousands of people, mostly women, wearing green, the color of the National Campaign for Legal, Safe, and Cost-Free Abortion. Described as a "marea verde" (in English, "green tidal wave"), these bodies

\footnotetext{
${ }^{18}$ Heagney, supra note 11 .

${ }^{19}$ Justice Ginsburg's account of the role that the Court's decision in Roe played in instigating social strife is not uncontested. See, e.g., Linda Greenhouse \& Reva B. Siegel, Before (and After) Roe v. Wade: New Questions About Backlash, 120 Yale L.J. 2028 (2011); Richard S. Price \& Thomas M. Keck, Movement Litigation and Unilateral Disarmament: Abortion and the Right to Die, 40 LAw \& SOC. INQUIRY 880 (2015).

${ }^{20}$ "Opposition mounted, and instead of fighting in the trenches, state by state, to retain restrictive abortion laws, there was one clear target to aim at: the unelected justices of the Supreme Court.” Rosen, supra note 11.

${ }^{21}$ See generally Harris v. McRae, 448 U.S. 297 (1980) (upholding Hyde Amendment, infra note 63).

${ }^{22}$ Planned Parenthood of Se. Pa. v. Casey, 505 U.S. 833, 874 (1992) (introducing new undue burden standard).

${ }^{23}$ See Melissa Murray, Race-ing Roe: Reproductive Justice, Racial Justice, and the Battle for Roe v. Wade, 134 Harv. L. Rev. 2025, 2092-93 (2021).

${ }^{24}$ Greenhouse \& Siegel, supra note 19, at 2030 (citing multiple instances of "Roe rage" since 1973). For example, New York Times columnist David Brooks has written: "When [the Supreme Court] issued the Roe v. Wade decision, they set off a cycle of political viciousness and counter-viciousness that has poisoned public life ever since." Id. (quoting David Brooks, Op-Ed, Roe's Birth, and Death, N.Y. Times, Apr. 21, 2005, at A23).
} 
were the physical manifestation of the grassroots political movement that had shifted the cultural tide in Argentina's public discourse on abortion. They were celebrating Law 27,610, the Voluntary Termination of Pregnancy Law ("IVE Law," for its initials in Spanish), ${ }^{25}$ the culmination of decades of activism firmly rooted in feminist theory and practice. ${ }^{26}$

Argentina's IVE Law decriminalizes abortion and provides unrestricted and fully-funded access to abortion services until the fourteenth week of pregnancy. ${ }^{27}$ Past the fourteen-week statutory limit, abortions may be obtained where the pregnant person's life is in danger or in cases of rape. ${ }^{28}$ The IVE Law places pregnant people-not their doctors-at the center of the decision-making process ${ }^{29}$ and explicitly frames the choice as a matter of health, equality, and dignity. ${ }^{30}$ Accompanying the IVE Law is the 1,000-Day-Plan, a statutory scheme which provides improved health care and nutritional services for pregnant people and newborns during the first 1,000 days of pregnancy and until the child's third birthday. ${ }^{31}$ Although the

${ }^{25}$ Law No. 27610, Jan. 15, 2021, Ley del Acceso a la Interrupción Voluntaria del Embarazo [Interrupción Voluntaria del Embarazo] [IVE Law] [34.562] B.O. 3 (Arg.), https://www.boletinoficial.gob.ar/detalleAviso/primera/239807/20210115

[https://perma.cc/KZQ8-J439]. See infra Appendix I for translation. Thirty-eight senators voted in favor of the bill, twenty-nine against, and one abstained. "Voluntary termination of pregnancy" is not a mere euphemism for abortion. The term IVE originated as a means by which to contrast "legal termination of pregnancy" (ILE, for its initials in Spanish), the nonpunishable abortions available under the previous version of Article 86. See Ministerio de Salud de la Nación, Acceso a la interrupción del embarazo: IVE/ILE, ARGENTINA.GOB.AR (Arg.), https://www.argentina.gob.ar/salud/sexual/acceso-la-interrupcion-del-embarazo-iveile [https://perma.cc/57AW-AT6C].

${ }^{26}$ Sandra Salomé Fernández Vázquez \& Josefina Brown, From Stigma to Pride: Health Professionals and Abortion Policies in the Metropolitan Area of Buenos Aires, 27 SEXUAL \& Reprod. Health Matters 65, 72 (2019) (crediting social movements rooted in feminism as the main engine for the social and legal changes that have reduced abortion stigma for pregnant people and for medical providers).

${ }^{27}$ IVE Law, art. 16 (Arg.) (amending the language of Penal Code, art. 86 to provide, in relevant part, that "An abortion performed with the consent of the pregnant person up until the fourteenth week of pregnancy is not a crime.”). See infra Appendix I for translation.

${ }^{28}$ Código Penal [Cód. Pen.] [Criminal Code] art. 86(1)-(2) (2021) (Arg.).

${ }^{20}$ Compare IVE Law, art. 4 (Arg.) (declaring the pregnant person's right to elect to terminate their pregnancy), with IVE Law, art. 5 (Arg.) (requiring that abortion services be provided no more than ten days after the request has been made).

${ }^{30}$ IVE Law, art. 3 (Arg.) (citing equality provisions of the Argentine Constitution; international treaties to which Argentina is a party, including the Convention on the Elimination of Discrimination Against Women; and "by virtue of the protections granted by sexual and reproductive rights, dignity, life, autonomy, health, education, integrity, bodily diversity, gender identity, ethno-cultural diversity, privacy, freedom of thought and belief, information, to enjoy the benefits of scientific advancements, true equality of opportunity, and against discrimination and a life free from violence") (translated into English by the author).

${ }^{31}$ Law No. 27611, Jan. 15, 2021, Ley Nacional de Atención y Cuidado Integral de la Salud Durante el Embarazo y la Primera Infancia [Salud Durante el Embarazo y la Primera 
IVE Law came to fruition forty-seven years after the U.S. Supreme Court's decision in Roe v. Wade, the Argentinian path to legal, safe, and cost-free abortion access via national legislation has created a deep cultural shift in attitudes about reproductive justice that will be difficult to undermine despite the reactionary mobilization of religious anti-abortion groups.

This Article offers a comparative study of abortion laws in the United States and Argentina, calling attention to how law and culture operate together to produce the social climate in which a pregnant person's ability to choose and access an abortion is acknowledged not just as a legal right but engrained into the social imagination as a human right and public health concern through deep changes in prevailing cultural norms.

The Article proceeds in three Parts. Because the history of abortion rights in the United States has been so well-documented by other scholars, Part III presents only a short summary of the Court's decision in Roe, followed by key legislative and judicial developments since 1973. Part III closes by previewing the narrow legal issue at stake in the Dobbs case, and by predicting the broad social impact that a ruling in favor of Mississippi would bring in that case. Because the corresponding history of abortion rights in Argentina is probably less well-known to U.S. audiences, Part IV is a more careful and detailed background of the legal regime that had the de facto effect of banning all abortions prior to 2020. Part IV also details various strategies utilized by the broad coalition of activists to advance reproductive justice as a social concern during the decades-long campaign to decriminalize abortion. Argentinian activists and legislators learned from the shortcomings of the U.S. experience and used this knowledge to improve both their organizing strategies and the substantive law.

Together, the first two Parts of this Article establish the background for Part V. Notably, whereas abortion rights in the United States can be tracked through a series of important judicial decisions, the Argentine reproductive justice movement is characterized by its use of multiple legal as well as extra-legal cultural reform strategies, which resulted in national legislation that ended a century-old abortion ban. Drawing on the cultureshifting thesis articulated by Thomas Stoddard, Part V introduces the culture-shift framework as a way to consider and evaluate the Argentine IVE Law and to predict whether, by advancing abortion rights through the slow process of grassroots activism and majoritarian politics, the IVE Law will be better able to withstand litigation. Part $\mathrm{V}$ predicts that while anti-abortion actors in Argentina may pursue litigation to enjoin the national law, those

Infancia] [1,000-Day Law] [34.562] B.O. 8 (Arg.). See infra Appendix II for translation. (Ley Nacional de Atención y Cuidado Integral de la Salud Durante el Embarazo y la Primera Infancia [1,000-Day-Plan] [Law 27,611, National Law for Comprehensive Health Care During Pregnancy and Early Childhood]. For a summary of the 1,000-Day Law, see Plan de los Mil Días: los principales puntos del proyecto que acompaña al aborto legal, PÁGINA 12 (Arg.) (Nov. 18, 2020), https://www.pagina12.com.ar/306454-plan-de-los-mil-dias-losprincipales-puntos-del-proyecto-que [https://perma.cc/A753-KMPF]. 
belated efforts at judicial reform will fail in large part because of the culture shift that has already been achieved by the reproductive justice movement.

The Article concludes with the observation that Argentina's activists learned important lessons from Roe, and proposes that, if Roe is overruled, U.S. activists will have much to learn from Argentina.

\section{ABORTION RIGHTS IN THE UNITED STATES}

The history of abortion in the United States is well-documented and other scholars have analyzed the U.S. Supreme Court's role in adjudicating abortion regulations. ${ }^{32}$ For this reason, here I trace only an abbreviated history, highlighting major events and excluding others in the development of the Court's jurisprudence regarding a constitutional right to abortion. This Part ends by providing additional details of the Dobbs case out of Mississippi, first mentioned in the Prelude to this Article. Dobbs may be the case that gives the conservative majority of the Court its opportunity to overrule Roe v. Wade.

\section{A. Pre-Roe}

Abortion was not always illegal in the United States. ${ }^{33}$ But after the Civil War and by the turn of the twentieth century, all states had anticontraceptive and anti-abortion legislation in place. ${ }^{34}$ Women and other

${ }^{32}$ See, e.g., Jill E. Adams \& Jessica Arons, A Travesty of Justice: Revisiting Harris v. McRae, 21 WM. \& Mary J. Women \& L. 5 (2014); Khiara M. Bridges, Elision and Erasure: Race, Class, and Gender in Harris v. McRae, in ReProd. RTs. \& Just. Stories 118 (Melissa Murray, Katherine Shaw \& Reva Siegel eds. 2019); Erwin Chemerinsky \& Michele Goodwin, Abortion: A Woman's Private Choice, 95 Tex. L. Rev. 1189 (2017); Linda Greenhouse \& Reva B. Siegel, The Difference a Whole Woman Makes: Protection for the Abortion Right After Whole Women's Health, 126 Yale L. J. F. 149 (2016); Melissa Murray, The Symbiosis of Abortion and Precedent, 134 Harv. L. REv. 308 (2020) (comment on the Supreme Court, 2019 Term); Reva Siegel, Reasoning from the Body: A Historical Perspective on Abortion Regulation and Questions of Equal Protection, 44 Stan. L. Rev. 261 (1992); Robin West, From Choice to Reproductive Justice: De-Constitutionalizing Abortion Rights, 118 Yale L. J. 1394 (2009); Mary Ziegler, Abortion and the LaW in America: Roe v. Wade to the Present (2020).

${ }^{3}$ Sybil Shainwald, Reproductive Injustice in the New Millennium, 20 WM. \& MARY J. WOMEN \& L. 123, 127 (2013) (noting that, in the period between 1607 and 1830, women had the right to abortion under the common law).

${ }^{34}$ See Murray, supra note 23, at 2034 (correcting the historical narrative regarding antiabortion laws in the United States by situating the rise of these laws in the years after 1808 and after the Civil War as motivated by the desire of slave owners to retain control over the production of their free work force); Reva Siegel \& Duncan Hosie, Trump's Anti-Abortion and Anti-Immigration Policies May Share a Goal, Time (Dec. 13, 2019), https://time.com/5748503/trump-abortion-immigration-replacement-theory/

[https://perma.cc/WF9K-VFAK] (linking the Trump administration's policies towards restricting abortion access and immigration as a "means of preserving a white, Christian 
persons with gestational capacity had few options to choose from in terms of reproductive decision-making until the 1960s when contraceptive pills became widely available. ${ }^{35}$ The right to use oral contraceptives was cemented in United States law when, in 1965, the Supreme Court recognized that constitutional privacy principles protected a woman's right to use birth control pills within her marriage. ${ }^{36}$ This birth control case, and the privacy rationale upon which it was based, set the stage for the Court's 1973 decision in Roe v. Wade.

\section{B. Roe v. Wade}

Jane Roe sought to terminate a pregnancy in $1969 .{ }^{38}$ Because Roe lived in Texas, her physician refused to perform an abortion because doing so would have subjected him to criminal prosecution under the strict antiabortion laws in force at that time. ${ }^{39}$ In 1969 , the Texas law was the most restrictive in the nation, imposing criminal sanctions on any person who either performed or procured an abortion, excepting only those necessary

America”); see also Roe v. Wade, 410 U.S. 113, 139 (referencing "the War Between the States" as the turning point after which states began to ban abortion practice through legislation).

${ }^{35}$ Claudia Goldin \& Lawrence F. Katz, The Power of the Pill: Oral Contraceptives and Women's Career and Marriage Decisions, 110 J. Pol. ECon. 730, 732-35 (2002) (noting that while the Food and Drug Administration approved the contraceptive pill in 1960, only married women took advantage of it because both state laws and community norms prohibited the use of the pill to young unmarried women until the 1970s).

${ }^{36}$ Griswold v. Connecticut, 381 U.S. 479 (1965) (striking a Connecticut law that banned the use of contraceptives in marriage, relying on a constitutional right to privacy theory). Unmarried women gained this right in 1972. Eisenstadt v. Baird, 405 U.S. 438, 453 (1972). In Baird, the Court explained how the constitutional right to privacy includes individual decisions about reproduction: "If the right of privacy means anything, it is the right of the individual, married or single, to be free from unwarranted governmental intrusion into matters so fundamentally affecting a person as the decision whether to bear or beget a child.” Id.

${ }^{37}$ See Murray, supra note 23, at 2049 (noting that Jane Roe's lawyers elected not to frame their arguments to the Court in terms of equality, but instead opted to pursue the privacy rationale). In 1973, the Court had not yet engaged in consideration of sex-based discrimination and intermediate scrutiny under the Equal Protection Clause. Rachel Rebouché \& Kimberly M. Mutcherson, Chapter 8: Roe v. Wade, in Feminist Judgments: Rewritten Opinions of The United States Supreme CourT 148 (Kathryn M. Stanchi, Linda L. Berger \& Bridget J. Crawford eds. 2016). The Court would not invent the intermediate scrutiny test for sex-based classifications until three years later, in 1976. Craig v. Boren, 429 U.S. 190 (1976). Of course, it would be another eight years before Sandra Day O'Connor would become the first woman nominated and confirmed to the Supreme Court. Sandra Day O'Connor \& H. Alan Day, Lazy B: Growing Up on a CatTle RanCH in the American Southwest (2003); Evan Thomas, First: Sandra Day O'Connor (2019).

${ }^{38}$ Roe, 410 U.S. at 120.

${ }^{39}$ Id. at $120-21$. 
to save the pregnant person's life. ${ }^{40}$ Texas physicians who performed abortions were subject to additional professional sanctions, such as the cancellation of their license to practice medicine. ${ }^{41}$

Although abortion was indeed a controversial social topic at the time, the Court that decided Roe was not bitterly divided in numbers or by partisan lines. The majority opinion was signed by seven of the nine justices. ${ }^{12}$ Republican presidents had appointed six of the justices on the Court at the time; four of them had been appointed by sitting President Richard Nixon, including Associate Justice Harry A. Blackmun. ${ }^{43}$ Justice Blackmun's majority opinion held that the Due Process Clause of the Fourteenth Amendment includes protection against state action that infringes upon the fundamental right to privacy. ${ }^{4}$ The Court concluded that a pregnant woman's privacy interests include the right to choose to have an abortion and determined that strict scrutiny should be imposed on state regulations of abortion access. ${ }^{45} \mathrm{In}$ its balancing-of-interests analysis, the Court considered the weight of the state's competing interest in protecting the "potentiality of human life" but concluded that this countervailing interest would vary over the course of a pregnancy and thus created a slidingscale test for all state regulations of abortion access over the three trimesters of a typical pregnancy. ${ }^{46}$

Although Roe is popularly understood to have been a victory for women's reproductive rights, it is not a feminist opinion. ${ }^{47}$ Per the Court, the central figure in the exercise of the constitutional right to privacy is not the pregnant person, but rather, their doctor. During the first trimester of the sliding-scale approach, the Roe Court accorded decision-making power "to the attending physician" as a primary matter and "in consultation with his patient" only as a secondary concern. ${ }^{48}$ The text of the Court's opinion

10 2A Tex. Penal Code, arts. 1191-94, 1196 (1961). Violation of the Texas abortion ban subjected physicians to a felony conviction, up to five years in prison, and cancellation of their license to practice medicine. Id. at art. 1191; 12B Tex. Rev. Civ. STAT. Ann., art. 4505 (1961).

"2A Tex. Penal Code, at art. 1191.

${ }^{12}$ Roe, 410 U.S. at 115. Justices Rehnquist and White dissented. Id.

${ }^{43}$ See Greenhouse \& Siegel, supra note 19, at 2031-32.

"Roe, 410 U.S. at 153.

${ }^{45} I d$. at 155 . The Court further explained what strict scrutiny required: where "'fundamental rights' are involved ... regulation limiting these rights may be justified only by a 'compelling state interest,' . . . and that legislative enactments must be narrowly drawn to express only the legitimate interests at stake." Id.

${ }^{46} \mathrm{Id}$. at $164-65$.

${ }^{47}$ See also Murray, supra note 23, at 2048-50 (marking the Roe Court's shift away from a feminist, equality-driven discourse to a privacy framework for abortion access). For a reimagined version of the opinion, written from a feminist perspective, read Rebouché \& Mutcherson, supra note 37.

${ }^{18}$ Roe, 410 U.S. at 163 . This is not an overstatement. The Court notes that it had considered 
with respect to privacy and decision-making during the first trimester reads:

$[\mathrm{F}]$ or the period of pregnancy prior to this "compelling" point, the attending physician, in consultation with his patient, is free to determine, without regulation by the State, that, in his medical judgment, the patient's pregnancy should be terminated. If that decision is reached [by the physician], the judgment may be effectuated by an abortion free of interference by the State. ${ }^{49}$

During the second trimester, the state may not ban abortions but "may, if it chooses, regulate the abortion procedure in ways that are reasonably related to maternal health." ${ }^{\text {50 }}$

During the final trimester of pregnancy, the Court shifted the balance of power towards the state, declaring: the state may "regulate, and even proscribe, abortion except where it is necessary, in appropriate medical judgment, for the preservation of the life or health of the mother." ${ }^{,{ }_{11}}$ In the majority's closing paragraphs, the Court reiterated the primacy of the physician's role in the abortion decision: "[T]he abortion decision in all its aspects is inherently, and primarily, a medical decision, and basic responsibility for it must rest with the physician. ${ }^{{ }^{2} 2}$

Roe marked the end of the second trimester as the relevant point in time where the state's interest in the health of the gestational parent could become "compelling" for the purpose of a constitutional balancing of interests. ${ }^{53}$ The majority was persuaded by the medical evidence that prior to this point, fetuses were not viable outside of the womb. ${ }^{54}$ States had the power to outlaw abortions only in the third trimester, "the stage subsequent to viability. ${ }^{955}$

Roe's three-trimester approach was interpreted by the Court to mean a ban on all pre-viability abortion regulations. The Court later abandoned the trimester distinctions and clarified: "viability marks the earliest point at which the State's interest in fetal life is constitutionally adequate to justify a legislative ban on nontherapeutic abortions. ${ }^{\text {"56 }}$ Viability is the critical marker for measuring a state's purported interest in protecting the life of a fetus

allowing the pregnant woman to make this decision on her own, the very argument asserted by Roe herself, but rejected this option in favor of the physician-oriented approach. As the Court explained: "[A]ppellant and some amici argue that the woman's right is absolute and that she is entitled to terminate her pregnancy at whatever time, in whatever way, and for whatever reason she alone chooses. With this we do not agree." Id. at 153.

${ }^{19} \mathrm{Id}$. at 163 .

${ }^{30} \mathrm{Id}$. at 164 .

${ }^{51}$ Id. at $164-65$.

${ }^{32}$ Id. at 166.

${ }^{53} I d$. at 163 .

${ }^{31} I d$.

${ }^{55}$ Id. at $164-65$.

${ }^{56}$ Planned Parenthood of Se. Pa. v. Casey, 505 U.S. 833, 860, 873 (1992). 
"because the fetus then presumably has the capacity of meaningful life outside the mother's womb. ${ }^{, 57}$ In the balancing of interests involved in assessing the exercise of a fundamental right, viability of the fetus serves as "independent existence of the second life." ${ }^{\text {s8 }}$ Roe's "central holding," therefore, is that "a State may not prohibit any woman from making the ultimate decision to terminate her pregnancy before viability." ${ }^{59}$

\section{Post-Roe}

The Court's decision in Roe immediately ignited a series of organized and coordinated reactions by anti-abortion interest groups. ${ }^{60}$ Although these groups existed before the decision, Roe $v$. Wade undoubtedly inspired the creation of new anti-abortion organizations. ${ }^{61}$ After Roe, organized antiabortion activists had realized the power of the Supreme Court to create national abortion policy, and thereafter, they adopted long-term legislative and litigation strategies with the ultimate goal of presenting anti-abortion arguments to the high court and changing precedent. ${ }^{62}$ And, despite their loss in Roe, they have been largely successful.

A few short years after Roe was decided on the grounds of physician expertise and patient privacy, Congress took the extraordinary step of cutting off federal funding to pay for the medical procedure. ${ }^{63}$ In 1980, the Court upheld the Hyde Amendment to the annual appropriations bill for the U.S. Department of Health and Human Services. ${ }^{64}$ Over Justice Thurgood Marshall's objections that the decision would disproportionately

\footnotetext{
i7 Roe, 410 U.S. at 163.

${ }^{58}$ Casey, 550 U.S. at 871.

${ }^{59} \mathrm{Id}$. at 879 .

${ }^{60}$ See Derrick Bell, Wanted: A White Leader Able to Free Whites of Racism, 33 U.C. DAvIS L. Rev. 527, 528 (2000) (citing Faye Wattleton, Life on the Line 209 (1996) (quoting political strategist David Garth who warned that the Roe decision could neutralize pro-choice politics by lulling the movement into a false sense of finality)).

${ }^{61}$ See, e.g., Linda C. McClain, Supreme Court Justices, Empathy, and Social Change: A Comment on Lani Guinier's Demosprudence Through Dissent, 89 Boston U. L. Rev. 589, 589 (2009); Emma Green, The Progressive Roots of the Pro-Life Movement, ATlantic (Feb. 3, 2016), https:/www.theatlantic.com/politics/archive/2016/02/daniel-williamsdefenders-unborn/435369/ [https://perma.cc/Q8FW-VNHQ]; Laura Bassett, The AntiAbortion Movement Was Always Built on Lies, GQ (May 20, 2020), https://www.gq.com/story/jane-roe-anti-abortion-lies [https://perma.cc/N8VB-2EX8].

${ }^{62}$ See, e.g., Steven G. Calabresi, How to Reverse Government Imposition of Immorality: A Strategy for Eroding Roe v. Wade, 31 HaRv. J. L. \& PUB. POL'Y 85 (2008).

${ }^{63}$ Consolidated Appropriations Act, 2014, Pub. L. No. 113-76, §§ 506-07, 128 Stat. 5, 409 (1977) (prohibiting the use of federal funds for abortion services, except in cases of rape, incest, or when the pregnancy endangers the gestational person's life) [hereinafter the Hyde Amendment]. Since its enactment, the Hyde Amendment has been renewed every year since.

${ }^{61}$ Harris v. McRae, 448 U.S. 297 (1980).
} 
impact poor, minoritized women, ${ }^{65}$ the majority in Harris V. McRae declared: "it simply does not follow that a woman's freedom of choice carries with it a constitutional entitlement to the financial resources to avail herself of the full range of protected choices. ${ }^{96}$ The Court later upheld an analogous prohibition on the use of state funds, facilities, or employees for abortion counseling and services. ${ }^{67}$

Litigation over state abortion regulations since Roe has gradually eroded both procedural and substantive protections for pregnant people seeking to exercise their right to terminate their pregnancies ${ }^{68}$ For example, in the 1992 Casey decision, the Court abandoned Roe's strict scrutiny test for evaluating state laws restricting abortion access and replaced it with a new "undue burden" standard. ${ }^{69}$ Nevertheless, Casey reaffirmed the viability standard announced by the Court in Roe. "Before viability, the State's interests are not strong enough to support a prohibition of abortion or the imposition of a substantial obstacle to the woman's effective right to elect the procedure. ${ }^{\text {"70 }}$ In the almost thirty years since Casey, the prohibition of pre-viability bans on abortion has held strong. ${ }^{71}$

Although substantial public disagreement about abortion existed before Roe, it is also fair to say that the Supreme Court's decision in that case directly precipitated now-longstanding social strife. At the level of electoral politics, a significant number of voters who self-identify as "pro-

${ }^{65}$ Id. at 343 (Marshall, J., dissenting) (warning that the Court's decision would burden "exclusively ... financially destitute women," a significant number of whom are members of minoritized racial groups).

${ }^{66}$ Harris, 448 U.S. at 316.

${ }^{67}$ Webster v. Reprod. Health Servs., 492 U.S. 490 (1989).

${ }^{68}$ See also infra Appendix III. In 1990, the Court held that a Minnesota law requiring minors to notify one parent before obtaining an abortion and imposing a forty-eight-hour waiting period did not violate constitutional privacy principles. Hodgson v. Minnesota, 497 U.S. 417 (1990). In 2007, the Court upheld the federal ban on the abortion procedure known as intact dilation and extraction. Compare Gonzalez v. Carhart, 550 U.S. 124 (2007), with Stenberg v. Carhart, 530 U.S. 914 (2000) (striking down a Nebraska law criminalizing the use of any "partial-birth" abortion procedure). In 2014, the Court invalidated a Massachusetts law that imposed a thirty-five-foot patient-safety zone to prevent harassment and intimidation from anti-abortion protestors outside abortion clinics. McCullen v. Coakley, 573 U.S. 464 (2014). ${ }^{69}$ Planned Parenthood of Se. Pa. v. Casey, 505 U.S. 833, 874 (1992). Cf. Roe v. Wade, 410 U.S. 113, 155 (1973) (imposing a "compelling state interest" standard on the state seeking to justify laws regulating abortion, because the right to abortion is fundamental under the Fourteenth Amendment).

${ }^{70}$ Casey, 505 U.S. at 846.

"See Jackson Women's Health Org. v. Currier, 349 F. Supp. 3d 536, 541-42 (S.D. Miss. 2018) (first citing Edwards v. Beck, 102 F.3d 1113, 1117 (8th Cir. 2015); then citing Sojourner T. v. Edwards, 974 F.2d 27, 30 (5th Cir. 1992); and then citing Gonzales v. Carhart, 550 U.S. at 146); Dobbs v. Jackson Women's Health Org., 945 F.3d 265, 272 (5th Cir. 2019) (citing Isaacson v. Horne, 716 F.3d 1213, 1215 (9th Cir. 2013)); MKB Mgmt. Corp. v. Stenehjem, 795 F.3d 768, 773 (8th Cir. 2015); Edwards v. Beck, 102 F.3d 1113, 1117 (8th Cir. 2015); Jane v. Bangerter, 102 F.3d 1112, 1115 (10th Cir. 1996). 
life" are single-issue voters. ${ }^{72}$ These single-issue voters report that they would only vote for a presidential candidate who shares their views. ${ }^{73}$ The division between anti-abortion and pro-choice voters is stark. In 2020, half of those polled in the United States supported abortion access, under certain circumstances. ${ }^{74}$ Forty-eight percent considered themselves to be pro-choice (compared to forty-six percent who considered themselves to be "prolife"). ${ }^{75}$ It is also true, however, that the fifty years since Roe has also brought stasis. The results of a 2019 survey showed that seventy-seven percent polled did not want the Supreme Court to overturn Roe. ${ }^{76}$

While the Hyde Amendment and Casey have undoubtedly altered the impact of Roe, the Supreme Court has not yet wavered from the "central principle" in Roe, that "before "viability ... the [pregnant person] has a right to choose to terminate [their] pregnancy."" unambiguously stated: "Regardless of whether exceptions are made for particular circumstances, a State may not prohibit any woman from making the ultimate decision to terminate her pregnancy before viability." ${ }^{\text {"8 }}$ The Dobbs case threatens to end the one constant in the Court's fluctuating approach to abortion regulations.

\section{Dobbs v.Jackson Women's Health Organization}

The abortion case currently before the Supreme Court revolves around a law passed by the Mississippi state legislature in 2018. The Mississippi law bans abortions after the fifteenth week of pregnancy (the "15-week law"). ${ }^{79}$ The fifteenth-week mark would be a strict barrier to access

${ }^{72}$ See Rebecca Riffkin, Abortion Edges Up as Important Voting Issue for Americans, GALluP (May 29, 2015), https://news.gallup.com/poll/183449/abortion-edges-importantvoting-issue-americans.aspx [https://perma.cc/A2Y4-VMZP].

${ }^{73}$ Most poll responders (forty-six percent) report that abortion is only one of many issues that matter to them, but twenty-one percent of those polled say that they will only vote for a candidate who shares their views on abortion. This 2015 result marked an all-time high for abortion single-issue voting in the history of Gallup polling. Id.

${ }^{74}$ Id.

75 Abortion, GaLluP, https://news.gallup.com/poll/1576/abortion.aspx [https://perma.cc/GM3S-X8PD].

${ }^{76}$ NPR/PBS NewsHour/Marist Poll of 944 National Adults, Marist Poll 9 (June 4, 2019), http://maristpoll.marist.edu/wp-content/uploads/2019/06/NPR_PBS-NewsHour_Marist-

Poll_USA-NOS-and-Tables-on-Abortion_1906051428_FINAL.pdf\#page=3

[https://perma.cc/82VB-PZGT].

${ }^{7}$ Stenberg v. Carhart, 530 U.S. 914, 921 (2000) (quoting Planned Parenthood of Se. Pa. v. Casey, 505 U.S. 833, 870 (1992)); see also June Med. Servs. v. Russo, 140 S. Ct. 2103, 2135 (2020) (Roberts, C.J., concurring) (using the term "most central principle in Roe v. Wade"). ${ }^{78}$ Casey, 505 U.S. at 879.

${ }^{79}$ Jackson Women's Health Org. v. Dobbs, 945 F.3d 265, 269 (2019) (citing Gestational Age Act, ch. 393, § 1, 2018 Miss. Laws (codified at Miss. Code AnN. § 41-41-191)). The 15week law provides: "Except in a medical emergency or in the case of a severe fetal 
because the law requires that a physician first determine and document a fetus's gestational age before performing an abortion. ${ }^{80}$ Immediately after the 15-week law came into force, Jackson Women's Health Organizationthe only licensed abortion clinic in the state-filed suit to enjoin the law. ${ }^{81}$ The U.S. District Court for the Southern District of Mississippi issued a temporary restraining order. ${ }^{82}$

In its November 2018 opinion, the district court concluded that the 15-week law "unequivocally" violated the Fourteenth Amendment due process rights of pregnant people and therefore granted summary judgment in favor of the clinic. ${ }^{83}$ Mississippi conceded that fetuses are not viable at fifteen weeks, and under a straightforward application of the viability standard announced in Roe and reaffirmed in Casey, the district court declared the law unconstitutional because "the State's interests are not strong enough to support a prohibition of abortion or the imposition of a substantial obstacle to the woman's effective right to elect the procedure." ${ }^{{ }^{* 4}}$ The district court's opinion, authored by Judge Carlton Reeve, is notable also because it emphasizes the dignity and autonomy values enshrined in the Fourteenth Amendment: "Mississippi’s law violates Supreme Court precedent, and in doing so it disregards the Fourteenth Amendment guarantee of autonomy for women desiring to control their own reproductive health." ${ }^{{ }^{5}}$

On appeal, the Fifth Circuit framed the issue before it as "whether [the 15-week law] is an unconstitutional ban on pre-viability abortions. ${ }^{{ }^{86}}$ Citing "an unbroken line" of Supreme Court cases dating from Roe, the Fifth Circuit declared: "States may regulate abortion procedures prior to viability so long as they do not impose an undue burden on the woman's right, but

abnormality, a person shall not intentionally or knowingly perform, induce, or attempt to perform or induce an abortion of an unborn human being if the probable gestational age of the unborn human being has been determined to be greater than fifteen (15) weeks.” Id. Prior to the 15-week law, Mississippi already had a separate law banning abortions after the twentieth week of pregnancy. Miss. CODE ANN. \$ 41-41-137.

${ }^{80}$ See Miss. Code AnN. \$ 41-41-191 (2018).

${ }^{81}$ Jackson Women's Health Org., 945 F.3d at 269.

${ }^{82}$ Jackson Women's Health Org. v. Currier, 349 F. Supp. 3d 536, 538 (S.D. Miss. 2018).

${ }^{83} \mathrm{Id}$.

${ }^{8}$ Id. at 539 (quoting Planned Parenthood of Se. Pa. v. Casey, 505 U.S. 833, 846 (citing Roe v. Wade, 410 U.S. 113 (1973))).

${ }^{85}$ Id. at 544. Judge Reeve's emphasis on dignity and autonomy recalls Justice Kennedy's majority opinion in Obergefell v. Hodges, 576 U.S. 644, 663 (2015) (recognizing that the Due Process Clause of the Fourteenth Amendment fundamental liberties "extend to certain personal choices central to individual dignity and autonomy, including intimate choices that define personal identity and beliefs") and Justice Ginsburg's dissenting opinion in Gonzales v. Carhart, 550 U.S. 124, 172 (2007) (Ginsburg, J., dissenting) ("[L]egal challenges to undue restrictions on abortion procedures do not seek to vindicate some generalized notion of privacy; rather, they center on a woman's autonomy to determine her life's course, and thus to enjoy equal citizenship stature.").

${ }^{86}$ Jackson Women's Health Org., 945 F.3d at 268-69. 
they may not ban abortions. ${ }^{{ }^{87}}$ Applying this rule to the Mississippi law, the court of appeals adopted the district court's rationale and similarly concluded that the 15-week law is a ban on pre-viability abortions and therefore violates the Casey standard. ${ }^{88}$ The Fifth Circuit observed that the district court's conclusion in Dobbs was consistent with that of all the circuit courts and district courts that had confronted similar pre-viability abortion bans. ${ }^{89}$

The Fifth Circuit rejected Mississippi's argument that the 15-week law was not a ban but merely a restriction on abortions and that therefore the district court should have made an "undue burden" determination under Casey instead of applying the pre-viability rule..$^{90}$ Mississippi argued that such a determination would have survived constitutional scrutiny because pregnant people could simply choose to seek an abortion before the fifteenth week. ${ }^{91}$ The only abortion provider in the state, Jackson Women's Health Organization, does not provide abortion services after the sixteenth week. ${ }^{92}$

In its petition for certiorari, Mississippi asked the Supreme Court to consider whether courts should make the "undue burden" determination under Casey when reviewing pre-viability abortion restrictions. ${ }^{93}$ The Court granted the cert petition but limited its consideration to a sole question"Whether all pre-viability prohibitions on elective abortions are unconstitutional."."4

Mississippi asserts that the only obstacle to finding that the state has the authority to restrict abortion access prior to viability is Supreme Court precedent. On the first page of its Petitioners' Brief, the state argues: "This case is made hard only because Roe v. Wade, 410 U.S. 113 (1973), and Planned Parenthood of Southeastern Pennsylvania v. Casey, 505 U.S. 833

${ }^{87}$ Id. at 269 .

${ }^{8} I d$. at 273-74 (distinguishing the 15-week law's ban on abortions from the abortion regulation upheld in Gonzales, 550 U.S. 124).

${ }^{89}$ Id. at 272 (first citing Isaacson v. Horne, 716 F.3d 1213, 1215 (9th Cir. 2013); then citing MKB Mgmt. Corp. v. Stenehjem, 795 F.3d 768, 773 (8th Cir. 2015); then citing Edwards v. Beck, 102 F.3d 1113, 1117 (8th Cir. 2015); then citing Jane v. Bangerter, 102 F.3d 1112, 1115 (10th Cir. 1996); then citing Preterm-Cleveland v. Yost, 394 F. Supp. 3d 796, 801 (S.D. Ohio 2019); then citing EMW Women's Surgical Ctr., P.S.C. v. Beshear, No. 3:19-CV-178, 2019 WL 1233575, at *2 (W.D. Ky. Mar. 15, 2019); then citing Bryant v. Woodall, 363 F. Supp. 3d 611, 629-32 (M.D.N.C. 2019); and then citing Little Rock Fam. Plan. Servs. v. Rutledge, 397 F. Supp. 3d 1213, 1220-21 (E.D. Ark. 2019)).

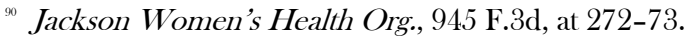

${ }^{91}$ Id. at 273.

${ }^{92}$ Id.

${ }^{93}$ Petition for Writ of Certiorari, at 20-27, Dobbs v. Jackson Women's Health Org., No. 191392 (U.S. June 15, 2020), available at https:/www.scotusblog.com/case-files/cases/dobbs-vjackson-womens-health-organization/ [https://perma.cc/RU52-PEZC].

${ }^{97}$ Certiorari Granted, Dobbs v. Jackson Women's Health Org., 141 S.Ct. 2619, 2619-20 (2021). 
(1992), hold that the Constitution protects a right to abortion." ${ }^{95}$ Mississippi contends that the solution to this problem is for the Court to overrule these cases $^{96}$ and to allow individual states to decide how to best protect their asserted interests in the health of the pregnant person, the regulation of the medical profession, and in the life of the unborn. ${ }^{97}$ Mississippi claims that Roe and Casey are "unworkable" precedents that "have inflicted severe damage," devoting nine full pages of its brief to the argument that these precedents are undemocratic assertions of judicial power. ${ }^{98}$

Petitioners' brief even cites to Justice Ginsburg's remarks during her 1984 Joyner Lecture at UNC School of Law. ${ }^{99}$ Instead of "bringing peace to the controversy over abortion, Roe and Casey have made matters worse," Mississippi argues. ${ }^{100}$ According to Mississippi: "The national fever on abortion can break only when this Court returns abortion policy to the States-where agreement is more common, compromise is often possible, and disagreement can be resolved at the ballot box." ${ }^{101}$

If Mississippi's arguments prevail in a high court currently dominated by conservative justices, the United States would revert back to a pre-Roe regime where pregnant peoples' access to abortion would be dependent on the majoritarian politics of each state legislature. In such a regime, pregnant people with financial means would still be able to obtain abortions but poor, young, and racially minoritized people would effectively be forced to carry their pregnancies to term or, as they did before Roe legalized abortion nationwide, to risk their lives by submitting their bodies to unregulated surgical procedures.

Not unlike the United States, in Argentina public opinion on abortion is divided. In November 2020, forty-one percent of poll responders supported decriminalizing abortion. ${ }^{102}$ In a separate poll, a majority of responders $(54.7 \%)$ asserted that abortion should be legal because the pregnant person has the right to decide. ${ }^{103}$ The following month, the

\footnotetext{
${ }^{95}$ Petitioners' Brief, supra note 3 , at 1.

${ }^{96}$ Id. at 14 .

${ }^{97}$ Id. at $7-8,11$.

${ }^{98} I d$. at $19-28$.

${ }^{99} I d$. at 3.

${ }^{100}$ Id. (citing Ginsburg, Joyner Lecture, supra note 8, at 385-86).

${ }^{101} I d$. at 24 .

${ }^{102}$ Statista Research Department, Level of Agreement with the Decriminalization of Abortion in Argentina as of November 2020 STATisTa (July 5, 2021), https://www.statista.com/statistics/818582/argentina-public-opinion-abortiondecriminalization/_[https://perma.cc/C68H-W7WC]; Poliarquía (@Poliarquia_), TwitTer (Dec. 10, 2020, 8:54 AM), https://twitter.com/Poliarquia_/status/1337048028440571907 [https://perma.cc/43BW-LDUS].

${ }^{103}$ CELAG Opinión Pública, Panorama Político y Social Argentina 13 (2020) (Arg.), https:/www.celag.org/wp-content/uploads/2020/11/encuesta-argentina-nov20-web.pdf [https://perma.cc/HJ36-HSEZ].
} 
Argentine Congress passed the IVE Law decriminalizing abortion. ${ }^{104}$ The new law structuring reproductive rights for pregnant people in Argentina goes much further than what the U.S. Supreme Court decided in Roe, however. The IVE Law explicitly references the pregnant person's ${ }^{105}$ rights to dignified treatment ${ }^{106}$ and autonomous decision-making, ${ }^{107}$ both of which are grounded in constitutional and human rights principles of substantive equality and anti-discrimination. ${ }^{108}$ The National Campaign for Legal, Safe, and Cost-Free Abortion not only won the right to choose an abortion but also the financial backing of the state to make the pregnant person's exercise of that choice a real option.

\section{REPRODUCTIVEJUSTICE IN ARGENTINA}

Following the abbreviated survey of abortion rights decisions in the United States above, this Part provides details about Argentina's long history of criminalizing abortion. Beneath the ostensible total ban on abortions, however, lay a narrow set of exceptions for legal (also known as "nonpunishable”) abortions. Against this legal regime, the grassroots feminist movements that emerged out of Argentina's military dictatorship dedicated themselves to multiple repertories of resistance to gender inequality, including working inside government to draft administrative regulations to make non-punishable abortions more accessible, litigation to defend the right to obtain non-punishable abortions, and the provision of direct services to pregnant people seeking abortion, all on top of legislative reform. ${ }^{109}$ The story of how the right to legal, safe, and cost-free abortion was won cannot easily be told in discrete and isolated steps because the IVE Law was the product of decades of political organizing, activism, and solidarity work. A product of the broader women's movement and rooted in feminist ideology, the National Campaign for Legal, Safe, and Cost-Free Abortion (the "Campaign") included an array of separate groups that coalesced around

${ }^{104}$ IVE Law (Arg.).

${ }^{105} I d$. at art. 1. The IVE Law uses inclusive language to describe the persons who have the right to choose an abortion-not just women, but all persons with gestational capacity, including trans and non-binary persons. $I d$.

${ }^{106} I d$. at art. 5(a).

${ }^{107} I d$. at art. $5(\mathrm{~d})$.

${ }^{108}$ Id. at art. 3. See also Legalizar el aborto también es luchar contra la discriminación, ARGENTINA.GOB.AR (Dec. 29, 2020) (Arg.), https:/www.argentina.gob.ar/noticias/inadi/legalizar-el-aborto-tambien-es-luchar-contra-ladiscriminacion [https://perma.cc/9HK8-TE2G] (explaining why abortion bans are tantamount to unlawful discrimination).

${ }^{109}$ See María Eugenia Monte, Abortion Liberalization Demand in Argentina: Legal Discourses as a Site of Struggle: A Case Study on the Structural Case Portal de Belén v. Córdoba (2012 2013), 5 OÑati SOCIAL-LEGAL SERIEs 1261, 1268-69 (2015) (recounting that the military dictatorship drove the Argentine feminist movements underground during the years 1976-1983) [hereinafter Monte, Abortion Liberalization]. 
the mass movement for reproductive justice. ${ }^{110}$ Through decades of on-theground organizing and activism, ${ }^{111}$ the movement that materialized as the Campaign created the cultural conditions in which Argentina's Congress passed two landmark pieces of progressive legislation-the IVE Law, which decriminalized abortion, and the 1,000-Day Plan, which advances the goal of reducing and preventing maternal morbidity and mortality by providing state support in the form of direct payments and free food and medicine to pregnant people and infant children.

Since Roe, abortion rights activists in the United States have relied mainly on legal arguments and the judicial doctrine of stare decisis to maintain the status quo. By contrast, the Argentine movement has been more diffuse in terms of its political strategies and organizing across varied sectors of politicized actors. Ultimately, this variegated strategy led to national legislative reform. To provide background about the legal and cultural context in which the Campaign organized for legal, safe, and costfree abortion, this Part will describe (1) the Penal Code provisions which criminalized abortion; (2) the multiple and overlapping strategies utilized by Campaign activists to make non-punishable abortions accessible, including legal and extra-legal means; and (3) the contents of the IVE Law and its complement, the 1,000-Day Plan.

\section{A. Pre-IVE Penal Code Provisions}

In Argentina's federal republic, ${ }^{112}$ criminal laws are determined at the national (not the provincial) level. ${ }^{113}$ Prior to $2021,{ }^{114}$ the Argentina Penal

${ }^{110}$ See, e.g., Verónica Gago \& Marta Malo, Introduction: The New Feminist Internationale, 119 S. ATL. Q. 620, 621 (2020) (describing the feminist movement in Argentina not in terms of "waves," but as a tide: "the movement of an aquatic mass composed of multiple subterranean currents, simultaneously flowing in many directions, forming an imaginary of movements as a multiplicity”); Fernández Vázquez \& Brown, supra note 26, at 67 (describing the Campaign as "a coalition of over 300 feminist, social and human rights movements and other non-governmental organisations (NGOs) from around Argentina ....”).

${ }^{11 \prime}$ See infra Appendix III for a chronology of important events in Argentine history surrounding the IVE Law.

${ }^{112}$ Santiago Legarre, Precedent in Argentina, 57 Loy. L. REv. 781, 786 n.20 (2012) (describing Argentina's system of federalism) [hereinafter Legarre, Precedent].

${ }^{113}$ Hector A. Mairal, Collective and Class Actions in Argentina, Glob. Class ACtions EXCH.

http://globalclassactions.stanford.edu/sites/default/files/documents/Argentina_National_Re port.pdf [https://perma.cc/DPB4-2VM3].

${ }^{114}$ The IVE Law, amending the text of the relevant Argentina Penal Code provisions, became effective on January 24, 2021. Karina Ocampo, Abortion in Argentina: The Challenge of Turning Latin America Green, AWID (Mar. 11, 2021), https://www.awid.org/news-andanalysis/abortion-argentina-challenge-turning-latin-america-green [https://perma.cc/36Q6$49 \mathrm{SH}]$. 
Code criminalized abortion, punishing both those who would perform ${ }^{1.5}$ and those who would procure ${ }^{116}$ an abortion. Depending on the underlying circumstances, violators could be punished from one to fifteen years in prison. ${ }^{117}$ Article 85, the code provision outlawing abortion, was first passed in the 1880 s, allowing no exceptions. ${ }^{118}$ In 1922, an amendment to Article 86 created three separate exceptions to Article 85's ban on abortions-in cases where the pregnant person's life or health was in danger, in cases of rape or indecent assault, or where the pregnant person was mentally disabled. ${ }^{119}$ After the military dictatorship ended and democracy returned in 1984, Article 86-the provision creating exceptions or "non-punishable abortions ${ }^{\not 20}$-was revised again. ${ }^{121}$ The removal of a comma in the revised text appeared to limit the class of non-punishable abortions to only two exceptions, by conflating the latter two categories. ${ }^{122}$ A narrow reading of the

${ }^{115}$ Código Penal [Cód. Pen.] [Criminal Code] art. 85 (as of Dec. 1, 2020) (Arg.) (translated as: "He who causes an abortion will be punished: 1 . with detention or prison from three to ten years, if the operation was carried out without the consent of the woman. This punishment may be raised to fifteen years, if the woman died as a result; 2 . with detention or prison of one to four years, if the operation was carried out with the consent of the woman. The maximum punishment is six years, if the woman died as a result." in Abortion: Argentina, Human Rights WaTch, https://www.hrw.org/legacy/women/abortion/argentina.html [https://perma.cc/5E9UMYHQ] [hereinafter HuMAN RighTs WATCH]).

${ }^{116}$ CÓD. PEN. art. 88 (as of Dec. 1, 2020) (Arg.) (translated as: "The woman who causes her own abortion or who consents to someone else causing it will be punished with one to four years of prison. The woman's attempt [to abort] is not punishable." in HuMAN RigHTS WATCH, supra note 115).

${ }^{117}$ Article 85 provided for penalties of up to ten years for abortion providers and Article 88 provided penalties of up to four years for patients who procure or cause their own abortion. Cód. Pen. arts. 85, 88 (as of Dec. 1, 2020) (Arg.).

${ }^{118}$ Agustina M. Buedo, Pregnancy, Femicide, and the Indispensability of Legalizing Abortion: A Comparison Between Argentina and Ireland, 34 EmOry InT'L L. Rev. 825, 825 n.3 (2020).

${ }^{119} I d$.

${ }^{120}$ María Eugenia Monte, Abortion, Sexual Abuse and Medical Control: the Argentinian Supreme Court Decision on F., A.L., 26 Sexualidad, Salud y Sociedad-Revista Latinoamericana 68, 70 (2017) [hereinafter Monte, Abortion].

${ }^{121}$ CóD. Pen. art. 86 (as of Dec. 1, 2020) (Arg.) provided (as translated in Human Rights WATch, supra note 115).

${ }^{122} I d$ :

The doctors, surgeons, midwives or pharmacists who abuse their science or profession to cause an abortion or cooperate to cause it will be punished as established in [Article 85] and will, additionally, be prohibited from exercising their profession for twice the time than that which they will serve. An abortion carried out by a medical doctor with the consent of the pregnant woman is not punishable:

1. if it was done with the objective to avoid a danger to the life or health of the mother and if this danger could not have been avoided by 
1984 amendment allowed for non-punishable abortions only in cases where the pregnant person's life or health is in danger, or in cases of rape committed against "an idiot or a demented woman." ${ }^{23}$

Despite the legal prohibitions on abortion, 400,000 clandestine abortions were performed each year in Argentina. ${ }^{124}$ Because these abortion services were unlawful, they were also unregulated and performed under dangerous and unsafe conditions. ${ }^{125}$ More than 50,000 women were treated at public hospitals for complications related to unsafe abortion practices. ${ }^{126}$ Since 1980, abortion was the leading cause of maternal morbidity in Argentina and more women died due to complications related to unsafe abortions in Argentina than in any other Latin American country. ${ }^{127}$ Not only did these pregnant women suffer health and safety consequences from seeking clandestine abortions, they also faced criminal prosecution. ${ }^{128}$

Under Article 88, those who procured or caused their own abortions were subject to one to four years in prison. ${ }^{129}$ As in other countries where abortion access is either banned or strictly regulated, prosecutions under the criminal abortion laws were not uncommon when pregnancies did not end in live births. ${ }^{130}$ In practice, the actual penalties for those accused of having abortions could be much more severe. Prosecutors in Argentina also used homicide laws to punish women who were even suspected of having obtained abortions. In a well-known case, a provincial court sentenced a woman known as Belén to eight years in prison under an aggravated homicide statute. ${ }^{131}$ After she sought medical care for abdominal pain, the

any other means;

2. if the pregnancy is the result of rape or assault to the modesty committed against an idiot or demented woman. In this case, the consent of the legal representative is required for the abortion.

See also Silvina Ramos, Mariana Romera \& Agustina Michel, Health Care Providers' Opinions on Abortion: A Study for the Implementation of the Legal Abortion Public Policy in the Province of Santa Fe, Argentina, 11 ReProd. HEalth 72 (2014) (discussing ambiguity in language of Article 86 and resulting narrow interpretation).

${ }^{123}$ Human Rights Watch, supra note 115.

${ }^{124}$ Ramos et al., supra note 122 , at 2.

${ }^{125} \mathrm{Id}$.

${ }^{126} I d$.

${ }^{127} I d$.

${ }^{128} \mathrm{Id}$.

${ }^{129}$ CóD. PEN. art. 88 (as of Dec. 1, 2020) (Arg.).

${ }^{130}$ Daniel Politi \& Ernesto Londoño, Argentina Legalizes Abortion in Milestone for Conservative Region, N.Y. Times (Dec. 30, 2020), https:/www.nytimes.com/2020/12/30/world/americas/argentina-legalizes-abortion.html [https://perma.cc/B74U-HANR] [hereinafter Politi \& Londoño, Argentina Legalizes Abortion].

${ }^{131}$ CóD. PEN. art. 80 (Arg.) (subjecting those who kill members of the family in the direct line of descendancy to life imprisonment but allowing for a sentence of imprisonment of eight to 
attending physician at the hospital diagnosed Belén as having suffered a miscarriage (in Spanish, aborto espontáneo), but police in the conservative province arrested her anyway. ${ }^{132}$ Belén served almost three years of that sentence before, assisted by human rights lawyers, she won her appeal in the provincial high court. ${ }^{133}$ Belén's case is not an isolated instance of aggressive prosecution. As of December 2020, at least 1,532 criminal abortion cases were pending. ${ }^{134}$

Faced with a de facto absolute abortion ban, the Campaign utilized a diffuse set of repertories or action strategies to achieve reform. ${ }^{135}$ The primary aim of the Campaign was to rewrite the Penal Code provisions criminalizing abortion to allow abortion on demand during the first trimester and thereafter as indicated. ${ }^{136}$ Inextricable from the Campaign's political project of legislative reform was the demand that abortion services would be available in public clinics and be publicly funded, just like any other health care service; ${ }^{137}$ thus, the Campaign's rallying cry: "Aborto Legal, Seguro y Gratuito," or in English, "Legal, Safe, and Cost-Free Abortion."

twenty-five years in cases involving extraordinary mitigating circumstances); Mar Centenera, Absuelta una joven argentina que estuvo dos años presa por un aborto, El PAís, (Mar. 28, 2017, $4: 45 \quad$ PM) (Arg.), https://elpais.com/internacional/2017/03/27/argentina/1490648400_185209.html

[https://perma.cc/3JQF-T5AT]; Argentina: Ruling to Release Woman Jailed After Miscarriage, a Step Forward for Human Rights, Amnesty InT'L (Aug. 17, 2016, 1:07 PM), https://www.amnesty.org/en/latest/news/2016/08/argentina-ruling-to-release-woman-jailedafter-miscarriage-a-step-forward-for-human-rights/ [https://perma.cc/5SM8-LB28].

${ }^{132}$ Centenera, supra note 131.

${ }^{133} \mathrm{Id}$.

${ }^{134}$ La criminalización por aborto y otros eventos obstétricos en la Argentina, CELS CENTRO DE Estudios Legales y Sociales [Center for Legal and Social Studies], (Dec. 28, 2020) (Arg.), https://www.cels.org.ar/web/publicaciones/la-criminalizacion-por-aborto-y-otroseventos-obstetricos-en-la-argentina/ [https:/perma.cc/N3YX-5EUJ]. In December 2020, Elizabeth Gómez Alcorta, Minister of the Department of Women, Gender, and Diversity, announced that these cases would immediately be dismissed because of the retroactive application of the IVE Law. Aborto legal I Elizabeth Gómez Alcorta estimó que la ley se reglamentará a inicios de la próxima semana, TN (Dec. 30, 2020, 9:45 PM) (Arg.), https://n.com.ar/politica/2020/12/31/aborto-legal-i-elizabeth-gomez-alcorta-estimo-que-laley-se-reglamentara-a-inicios-de-la-proxima-semana/ [https:/perma.cc/H546-Q8FE].

${ }^{135}$ See Monte, Abortion Liberalization, supra note 109, at 1264.

${ }^{136} I d$. at 1271 .

${ }^{137} I d$. at 1271-72. Notably, this includes post-abortion medical services. IVE Law, art. 1 (Arg.) ("This Act regulates access to voluntary interruption of pregnancy and access to postabortion medical care ....”) (translated into English by the author).

${ }^{138}$ The Campaign's key slogan, while a bit longer, reveals the comprehensive nature of the demands for reproductive justice: "[e]ducación sexual para decidir, [a]nticontraceptivos para no abortar y [a]borto legal para no morir." (In English, "sexual education to decide, contraceptives to avoid abortion, and legal abortion to not die.”) (translated into English by the author). Lema de la Campaña - Argumentos, Campaña Nacional por el Derecho al Aborto Legal, Seguro y Gratuito (Jan. 27, 2008) (Arg.), 
Campaign activists helped deliver legislative proposals to the Argentinian Congress on a biannual basis beginning in 2007, ${ }^{139}$ but importantly, the Campaign's political strategy was not limited to legislative reform. The Campaign also pursued incremental changes in policy and practice by participating in administrative regulation drafting, through litigation regarding non-punishable abortions, and also by providing direct services to pregnant people seeking abortions. ${ }^{140}$ With each move, and guided by feminist praxis at each step, the Campaign brought the debate about abortion into the public sphere and literally made it visible through the ubiquitous use of the color green. ${ }^{141}$ Through a recursive series of advances and setbacks, public attitudes about abortion shifted over time, eventually providing the palpable cultural shift necessary to give politicians the incentive to vote for the IVE Law. ${ }^{142}$

\section{B. Multiple Repertories of Resistance}

The 2020 IVE Law refers to the voluntary interruption of pregnancy to distinguish it from the legal interruption of pregnancy ("ILE" for its initials in Spanish). Legal exceptions to the pre-IVE abortion ban had existed since 1922-for the health and safety of the mother, in cases of rape or indecent assault, or, as described above, in cases of the rape or indecent assault of "an idiot or demented woman." ${ }^{143}$ The Penal Code's formal list of legal exceptions or non-punishable abortions, however, did not correspond with actual legal access to abortion. ${ }^{14}$ Instead, conservative actors succeeded in imposing a de facto absolute ban where even non-punishable abortions

http://www.abortolegal.com.ar/lema-de-la-campana-argumentos/ [https://perma.cc/5B25$\mathrm{ZPQH}]$.

${ }^{139}$ Barbara Sutton \& Nayla Luz Vacarezza, Abortion Rights in Images: Visual Interventions by Activist Organizations in Argentina, 45 SigNs 731, 752 (2020).

${ }^{140}$ Monte, Abortion Liberalization, supra note 109, at 1272. Monte also notes that reforms in administrative regulation drafting were important. Id. By 2007, the National Ministry of Health published the Guía Técnica para la Atención Integral de los Abortos no Punibles. Activists from the Campaign were involved in drafting these administrative laws that state the processes that health care professional follow when abortions are sought by people who became pregnant as the result of rape, when the person has developmental disabilities, or where the pregnant person's health is in danger. Id. at 1264, 1272. These conditions were known as the class of non-punishable abortions because the Penal Code provided exceptions in these cases. Id. at 1264 .

${ }^{141}$ Id. at $1269-71$.

${ }^{112}$ Id. at $1271-72$.

${ }^{143}$ CÓD. Pen. art. 86 (as of Dec. 1, 2020) (Arg.) (as translated in Human Rights Watch, supra note 115); Buedo, supra note 118.

14 Paola Bergallo, The Struggle Against Informal Rules on Abortion in Argentina, in abortion Law in Transnational Perspective: Cases and Controversies 143 (Rebecca J. Cook, Joanna N. Erdman \& Bernard M. Dickens eds., 2014) (drawing a distinction between the formal rule for non-punishable abortion classes in Article 86 and the informal regime that imposed a de facto absolute ban on abortion access). 
(i.e., legal abortions under Article 86) were impossible to obtain. ${ }^{145}$ Under this regime, medical professionals were uncertain whether, and under what circumstances, they were allowed to provide abortion services. ${ }^{166}$ Beginning in 2002, however, the seeds of a multidimensional approach were planted to obligate the public health care system to provide access to these nonpunishable abortions. ${ }^{147}$

\section{Collaborating with Government Agencies}

One of those strategies was for Campaign affiliates to coordinate efforts with the national and provincial ministries of health to draft and circulate procedural regulations for the non-punishable abortions already provided for by Article 86. While criminal laws are applicable nationwide in Argentina, administrative and procedural laws can either be national or provincial in scope. ${ }^{148}$ Health care providers were uncertain what type of proof, if any, was necessary to support the request for an Article 86 nonpunishable abortion. Without administrative guidance, medical providers and judicial actors had relied on their own discretion in determining whether, for example, police or judicial pre-authorization was necessary before medical clinics could offer abortion services.

In 2007, the National Ministry of Health tasked the National Program on Reproductive Health and Responsible Parenthood, a governmental body created by the 2002 National Reproductive Health Law, to develop administrative regulations for the implementation of Article 86 nonpunishable abortions. ${ }^{149}$ The Health Ministry mandated that the World Health Organization's ("WHO") abortion guidance should serve as a model for this project. ${ }^{150}$ The WHO's Safe Abortion: Technical and Policy Guidelines for Health Systems established a broad understanding of what is meant by the "health" of the pregnant person in relation to abortion regulations. The $\mathrm{WHO}$ applies a comprehensive definition of health that

${ }^{145} I d$. at $143-44$

${ }^{146}$ See Ramos et al., supra note 122. The 1984 amendment to Art. 86 left in doubt whether abortions could be provided in all cases of rape and incest or only in cases where women with mental deficiencies were victims of rape and incest. As a result of this constitutional ambiguity, conservatives succeeded in establishing a de facto absolute ban on abortions in the period immediately after the dictatorship. Bergallo, supra note 144, at 144-45.

${ }^{147}$ Id. at 147 (citing Ley de salud sexual y procreación responsable [Responsible Sexual and Reproductive Health Law], Law No. 25.672 (2002) (Arg.) as a catalyst).

${ }^{118}$ Mairal, supra note 113, at 1.

${ }^{149}$ Bergallo, supra note 144 , at 153 . The impetus for the creation of these administrative regulations was a recommendation issued by the National Institute Against Discrimination, Xenophobia, and Racism ("INADI" for its initials in Spanish), which framed the issue of regulations for non-punishable abortions as an anti-discrimination one. Id.; INADI, Recomendación № 2: Discriminación en la Atención SANitaria de Casos de Abortos Legales y Tratamiento Postaborto (2007) (Arg.).

${ }^{150}$ Bergallo, supra note 144, at 153. 
includes mental and social as well as physical health, "not merely the absence of disease or infirmity." ${ }^{151}$

The proposed national administrative guidelines were meant to provide regulatory information for health care facilities providing nonpunishable abortions under Article 86. The first Guía Técnica para la Atención Integral de los Abortos no Punibles ("Technical Guide") was finalized in 2007. ${ }^{152}$ Importantly, the regulations contained in the 2007 Technical Guide were the product of collaborative efforts between Health Ministry officials and Campaign affiliates. ${ }^{153}$ At this level, Campaign affiliates included feminist lawyers and public health experts, many who had ties to the think tank Center for Studies on State and Society ("CEDES" for its initials in Spanish). ${ }^{154}$ Feminist advocates consciously participated in this incremental strategy of changing public policy from inside government and public health institutions. ${ }^{1.55}$ Campaign members worked closely with government agencies at the national and provincial levels, developing professional relationships with decisionmakers within state bureaucracy and in the public health sector. ${ }^{156}$ Besides collaborating to create legal documents

${ }^{151}$ World Health Org., Safe Abortion: Technical and Policy Guidelines for Health Systems 92 (2d ed. 2012) (quoting Const. of the World Health Org., 47th ed., World Health ORG. (2009) (“[H]ealth is 'a state of complete physical, mental and social well-being and not merely the absence of disease or infirmity.").

${ }^{152}$ In English, the Technical Guide for the Comprehensive Care of Legal [Non-Punishable] Abortion. Monte, Abortion Liberalization, supra note 109, at 1272.

${ }^{153}$ Id. at 1264; Julia McReynolds-Pérez, Abortion as Empowerment: Reproductive Rights Activism in a Legally Restricted Context, 17 BMC PregnanCy \& ChILdBIRTH 95, 99 (2017); Ana Cristina González Vélez, "The Health Exception”: A Means of Expanding Access to Legal Abortion, 20 ReProd. Health MatTers 22 (2012).

${ }^{15}$ Alba Ruibal \& Cora Fernandez Anderson, Legal Obstacles and Social Change: Strategies of the Abortion Rights Movement in Argentina, 8 PoL., GrPs., \& Identities 1, 8 (2018). CEDES later partnered with other organizations to create a network of public health sector workers, including physicians, social workers, lawyers, and other advocates "to facilitate women's access to safe and legal abortion.” This network was named Red Nacional de Referentes de Acceso al Aborto ("REDAAS"). RED NACIONAL DE REFERENTES DE ACCESO AL ABORTO (REDAAS) (Arg.), http://www.redaas.org.ar/english [https://perma.cc/44WVRWYS]. Paola Bergallo, Silvina Ramos, and Mariana Romero are listed as three of the authors of the 2007 Technical Guide, along with Valeria Isla, the Director of the Department of Sexual and Reproductive Health of the National Ministry of Health. Bergallo is a lawyer and law professor at the University of Torcuato de Tella Buenos Aires. Ramos is a Senior Researcher at CEDES. Romero is the Executive Director of CEDES and a member of the coordinating group for REDAAS.

${ }^{155}$ Ruibal \& Fernandez Anderson, supra note 154, at 9; see also Alisha Haridasani Gupta \& Daniel Politi, These Three Feminists are Changing Argentina from the Inside, N.Y. TIMES (May 11, 2021), https://www.nytimes.com/2021/05/11/world/feminists-argentinagovernment.html_[https://perma.cc/5MDP-SZ4R] (discussing how self-identified feminist women leaders, among them Vilma Ibarra, author of the IVE bill, are working from inside the Fernández administration to make significant policy changes to benefit women and other minoritized genders).

${ }^{156}$ Ruibal \& Fernandez Anderson, supra note 154, at 8-9. 
such as the Technical Guide, Campaign activists worked from inside institutions to develop capacities of health care providers through workshops and trainings. ${ }^{1.57}$

Although the Technical Guide was finalized in 2007, it was not approved before a new president came into power. ${ }^{158}$ President Cristina Fernández de Kirchner appointed a new Minister of Public Health in late 2007, and progress on approving and releasing the national Technical Guide went dormant for several years. ${ }^{159}$

\section{Litigation}

During the interim period before the Technical Guide was finally approved in 2015, pregnant people seeking non-punishable abortions at public facilities would frequently be denied access to the procedure. ${ }^{160}$ Without national administrative regulations, neither medical providers nor judicial actors had any guidance about whether judicial pre-authorizations for non-punishable abortions were necessary. ${ }^{161}$ The Argentinian Supreme Court's 2012 F., A.L. case illustrates this not uncommon set of facts.

A mother, A.F., filed criminal charges in the provincial court of Chubut against her husband, O.C., the man who raped and impregnated her daughter, A.G. ${ }^{162}$ Thereafter, as a proactive measure, A.F. also sought a judicial order to authorize an abortion for A.G. based on the Article 86 rape exception. ${ }^{163}$ In that process, the provincial court judge ordered that various parties deemed to have an interest in the proceedings file briefs and reports to the court. ${ }^{164}$ The judge also ordered the intervention of two parties who requested protective measures to prevent the abortion-the Advisor of

${ }^{157}$ Id. at 9 .

${ }^{158}$ Bergallo, supra note 144, at 153.

${ }^{159} I d$. at 253. In the interim, individual provinces were left to come up with their own administrative regulations (e.g., the Province of Santa Fe adopted the 2007 Technical Guide in 2009). Id. at 255.

${ }^{160}$ Monte, Abortion Liberalization, supra note 109, at 1273. A 2014 study of two public hospitals in Santa Fe Province revealed that health care providers who serve as gatekeepers to abortion access were ignorant or uninformed about the legal framework for nonpunishable abortions. Notably, very few of these health care professionals knew that both rape and risk to the pregnant person's mental and physical health were legal bases for nonpunishable abortions. Ramos et al., supra note 122, at 2.

${ }^{161}$ Monte, Abortion Liberalization, supra note 109, at 1273.

${ }^{162}$ Corte Suprema de Justicia de la Nación [CSJN] [National Supreme Court of Justice], 13/3/2012, "F., A. L. s/ medida autosatisfactiva," Fallos (2012-335-197), I 1 (Arg.), https:/www.cij.gov.ar/nota-8754-La-Corte-Suprema-preciso-el-alcance-del-aborto-nopunible-y-dijo-que-estos-casos-no-deben-ser-judicializados.html [https://perma.cc/H5ZFU4ZS]. The man who attacked A.G. was A.F.'s husband, O.C. Id.

${ }^{163}$ Id:; Monte, Abortion, supra note 120, at 72-73.

${ }^{161}$ Monte, Abortion, supra note 120, at 73. 
Family and Disabled and a guardian ad litem for unborn children. ${ }^{165}$

Despite evidence that fifteen-year-old A.G. faced severe health consequences by bringing her pregnancy to term, the judge ruled that A.G.'s situation did not qualify for authorization of a nonpunishable abortion. ${ }^{166}$ Article 86 , subsection 2 provided:

An abortion carried out by a medical doctor with the consent of the pregnant woman is not punishable[l . . . if the pregnancy is the result of rape or assault to the modesty committed against an idiot or demented woman. In this case, the consent of the legal representative is required for the abortion. ${ }^{167}$

The judge reasoned that although A.G. had been the victim of rape, subsection 2 contemplated non-punishable abortion access only for women with disabilities, not all women who had been raped or sexually assaulted. ${ }^{168}$ The judge further ordered protective measures designed to "contain[l” A.G. until she gave birth. ${ }^{169}$

Fortunately, A.G.'s case garnered national media attention and the decision was appealed, this time with a number of women's and feminist organizations serving as amici. ${ }^{170}$ The provincial appellate court affirmed the judge's decision to deny the abortion petition. ${ }^{171}$ Eventually, however, A.G. obtained an abortion at a public health care facility after the provincial Superior Tribunal held that the judge below never had authority to consider the original petition from A.F. ${ }^{172}$

The case did not stop there. Asserting standing on behalf of unborn children, the provincial government of Chubut took the case to the Argentine Supreme Court ("CSJN" for its initials in Spanish). ${ }^{173}$ Although the case was now moot, the CSJN issued a decision because of the significant national implications of the facts presented by the case. ${ }^{174}$ In its March 2012 opinion, the CSJN held that Article 86, Subsection 2 did not limit non-

${ }^{165}$ Id. at 73; CSJN, 13/3/2012, “F., A. L. s/ medida autosatisfactiva," Fallos (2012-335-197), I 3.

${ }^{166}$ CSJN, 13/3/2012, “F., A. L. s/ medida autosatisfactiva,” Fallos (2012-335-197), II 1. A.G. was depressed and expressed suicidal ideations at the idea of giving birth to the child of her stepfather, placing her psychological and physical health "in grave danger." Id.

${ }^{167}$ CóD. Pen. art. 86 (as of Dec. 1, 2020) (Arg.) (as translated in Human Rights Watch, supra note 115).

${ }^{168}$ CSJN, “F., A. L. s/ medida autosatisfactiva,” Fallos (2012-335-197), I 3.

${ }^{169}$ Monte, Abortion, supra note 120, at 73.

${ }^{170}$ CSJN, “F., A. L. s/ medida autosatisfactiva,” Fallos (2012-335-197), II 4.

${ }^{171}$ Monte, Abortion, supra note 120, at 73.

${ }^{172}$ CSJN, "F., A. L. s/ medida autosatisfactiva," Fallos (2012-335-197), II 2; Monte, Abortion, supra note 120 , at 74 .

${ }^{173}$ CSJN, “F., A. L. s/ medida autosatisfactiva,” Fallos (2012-335-197), II 3-4.

${ }^{17 \pi}$ Id. at $\mathbb{I} 5$ (citing the U.S. Supreme Court's decision in Roe for a pregnancy exception to the mootness doctrine); Monte, Abortion, supra note 120, at 74. 
punishable abortions to women with disabilities. ${ }^{175}$ Furthermore, the CSJN ruled that no judicial process was necessary before seeking a non-punishable abortion. ${ }^{176}$ Instead, the pregnant person was only required to make a certified statement, in front of their physician, that the pregnancy was a result of sexual assault. ${ }^{177}$ The CSJN made clear that the pregnant person would not have to initiate criminal charges against their attacker nor provide any other judicial proofs to gain access to non-punishable abortion. ${ }^{178}$ In addition, the CSJN also held that public health care services had a duty to provide access to non-punishable abortions, even if individual physicians were entitled to assert status as conscientious objectors to the practice. ${ }^{179}$ It ruled that delays or other obstructions to non-punishable abortion access by health care providers were unlawful. ${ }^{180}$

Importantly, in reaching its decision, the CSJN considered and rejected Chubut's arguments that the right to life provisions found in the Argentine Constitution and various international treaties to which Argentina is a party prevented the formulation of regulations to make non-punishable abortions under Article 86 more readily accessible. ${ }^{181}$ Indeed, the CSJN reviewed the same provisions cited by Chubut and explained that it had a responsibility to interpret the Penal Code provision in harmony with its constitutional and international obligations. ${ }^{182}$ The CSJN recognized that non-punishable abortions under Article 86 were a human right and that the state had a duty under the Constitution and human rights treaties to guarantee that right. ${ }^{183}$

The CSJN called on the national and provincial governments to approve administrative regulations that would remove similar barriers to non-punishable abortions in public health care facilities. ${ }^{184}$ The Province of Chubut, the setting for F., A.L., passed a law establishing Article 86 abortions two months later. ${ }^{185}$ The $F$., A.L. decision inspired a wave of

${ }^{175}$ CSJN, “F., A. L. s/ medida autosatisfactiva,” Fallos (2012-335-197), I 15; Monte, Abortion, supra note 120, at 75; Bergallo, supra note 144, at 165.

${ }^{176}$ CSJN, "F., A. L. s/ medida autosatisfactiva,” Fallos (2012-335-197), III 18, 21; Monte, Abortion, supra note 120, at 76. Recall that A.G.'s mother sought a judicial order to authorize a non-punishable abortion for A.G., who became pregnant as a result of a rape. CSJN, "F., A. L. s/ medida autosatisfactiva,” Fallos (2012-335-197), I 1.

${ }^{177}$ CSJN, "F., A. L. s/ medida autosatisfactiva,” Fallos (2012-335-197), I 27; Monte, Abortion, supra note 120 , at 77 .

${ }^{178}$ CSJN, “F., A. L. s/ medida autosatisfactiva,” Fallos (2012-335-197), \ 27; Monte, Abortion, supra note 120 , at 76 .

${ }^{179}$ Monte, Abortion, supra note 120, at 77.

${ }^{180}$ Id. at 75 .

${ }^{181}$ See CSJN, "F., A. L. s/ medida autosatisfactiva,” Fallos (2012-335-197), II 3.

${ }^{182}$ See id. at III 7-17.

${ }^{183}$ Id. at $\mathbb{1}$ II $15,26$.

${ }^{184}$ Bergallo, supra note 144, at 167.

${ }^{185}$ Id. at 154 (citing Law XV No. 14, Chubut, May 31, 2010, Ley provincial de procedimientos 
reforms to provincial regulations and eventually to a 2015 revision to the Technical Guide. ${ }^{186}$ The National Health Ministry's 2015 Technical Guide explained that doctors may perform abortions in cases of rape or whenever the pregnant person's health is in danger ${ }^{187}$ Following the CSJN's decision in F., A.L., the 2015 Technical Guide further clarified that the rape exception was not limited to victims with developmental disabilities. ${ }^{188}$ The F., A.L. case also inspired conservative backlash that would play out in the courts.

Shortly after the CSJN published F., A.L., the Province of Córdoba enacted law codifying the decision. Córdoba's Resolution 93/12 specifically invoked the $F$, A.L. decision by allowing health care providers to perform non-punishable abortions under Subsection 2 with the sole requisite of the pregnant person's statement certifying the factual basis for the exception in front of a physician. ${ }^{189}$ Immediately following passage of Resolution 93/12, however, an anti-abortion, religious organization called Portal de Belén filed an injunction to prevent the Province of Córdoba from enforcing the law. ${ }^{190}$ The day after the lawsuit was filed, the provincial court suspended enforcement of Resolution 93/12, pending resolution of the case..$^{191}$ This did not happen until November 2018 when the provincial high court finally dismissed the lawsuit. ${ }^{192}$ In other words, the right to access non-punishable abortion under the process delineated by the CSJN in F., A.L. was suspended in the Province of Córdoba for close to seven years.

a desarrollar en los establecimientos de salud pública, respecto de la atención de los casos de abortos no punibles [Act to Develop Public Health Facilities for the Treatment of NonPunishable Abortions] [Año LII - N 10996] B.O. 2 (Arg.). Law XV came two months after the provincial Superior Tribunal ruled that the trial judge lacked jurisdiction in the first instance. $I d$.

${ }^{186}$ Monte, Abortion, supra note 120, at 78. In 2012, the province of Córdoba had enacted law codifying the decision in F., A.L. Resolution 93/12, like similar legislation in other provinces, specifically invoked the CSJN decision when requiring only a certified statement in front of a physician to obtain a non-punishable abortion. Id. at 78-79.

${ }^{187}$ The Ministry adopted the World Health Organization's broad definition of health: "a state of complete physical, mental, and social well-being, and not just an absence of illness." Ciara Nugent, How a Network of Activists Are Helping Women Get Abortions in Argentina During Coronavirus Lockdown, TiMe (May 1, 2020, 10:10 AM), https://time.com/5830687/argentina-abortion-coronavirus/ [https://perma.cc/K3JJ-5CHA]; see also Ministerio de Salud, Protocolo para la atención integral de las PERSONAS CON DERECHO A LA INTERRUPCIÓN LEGAL DEL EMBARAZO (2019) (Arg.), http://iah.salud.gob.ar/doc/433.pdf [https://perma.cc/F4LG-9ZPA].

${ }^{188}$ Bergallo, supra note 144, at 156.

${ }^{189}$ Monte, Abortion, supra note 120, at 78-79.

${ }^{190}$ Id. Córdoba passed Resolution 93/12 on March 30, 2012, and Portal de Belén filed suit on April 12, 2012. Id.

${ }^{191}$ Monte, Abortion Liberalization, supra note 109, at 1274.

${ }^{192}$ Mayca Balaguer, EI TSJ rechazó los planteos de Portal de Belén en la causa de aborto no punible, FundePs (Nov. 14, 2018) (Arg.), https://www.fundeps.org/tsj-rechazo-portal-belen/ [https://perma.cc/HM85-JM45]. 


\section{Direct Services for Pregnant People}

As previously stated, the grassroots social movement for legal abortion did not rely solely on legal strategies such as litigation or drafting regulation. Existing alongside the court battle over the Technical Guide were the direct service actions of feminist and queer groups that provided information and support for pregnant people seeking abortions. The Socorristas en RedFeministas que Abortamos, ${ }^{193}$ a network of feminist organizations, supplied contacts and information about medically-induced abortions. ${ }^{194}$ The Socorristas provided a more organized and digitally-savvy means of distributing information than the passing of a scrap of paper with a sympathetic doctor's phone number on it. ${ }^{195}$ Socorristas served as personal escorts and accompaniment support, in particular for those seeking secondtrimester abortions. ${ }^{196}$ These services were offered both in-person and over the phone, and importantly included post-abortion care and support. ${ }^{197}$

While most Socorristas were not medical personnel, each underwent extensive training in the feminist principles upon which the organization was based and extensive training in extant medical guidelines. ${ }^{198}$ These feminist principles and goals include: providing information so that the pregnant person can make an autonomous decision; offering compassionate abortion accompaniment care in a non-judgmental space; working with health professionals to generate empathetic and anti-discriminatory care for people seeking abortions; and advocacy for decriminalizing abortion. ${ }^{199}$ The feminist values and demands for autonomy, empathy, and antidiscrimination would later find echoes in the text of the IVE Law. ${ }^{200}$

Some organizations actually provided abortion services. Profesionales

\footnotetext{
${ }^{193}$ In English, "the Network of first responders-Feminists who abort." (translated into English by the author). See also Ruth Zurbriggen, Brianna Keefe-Oates \& Caitlin Gerdts, Accompaniment of Second-Trimester Abortions: The Model of the Feminist Socorrista Network of Argentina, 97 Contraception 108, 109 (2018) (translating the name of the organization as "Network of Feminist Providers of Aid and Abortion Support").

${ }^{194}$ Sutton \& Vacarezza, supra note 139, at 746; Cf. Natalie Alcoba, Argentina's Underground Abortion Network Won't Let a Pandemic Get in Its Way, Vice (Aug. 5, 2020), https://www.vice.com/en/article/jgxapy/argentina-socorristas-abortion-access-during-covid [https://perma.cc/YX82-KU6C] (describing how the Socorristas are functioning during the COVID-19 pandemic).

${ }^{195}$ See, e.g., Carla McKirdy, Argentina's Underground Abortion Clinics, BUST (Sept. 16, 2021), https://bust.com/living/16431-underground-abortion-clinics.html [https://perma.cc/Q6AR-RUQW] (describing the story of a woman named Hannah); Zurbriggen et al., supra note 193, at 110 (outlining the services performed by Socorristas, through its model of action).

${ }^{196}$ Zurbriggen et al., supra note 193, at 110.

${ }^{197}$ Id.

${ }^{198} I d$. at 109.

${ }^{199}$ Id. at $109,111$.

${ }^{200}$ See infra Part V.C; Appendix I.
} 
de la Salud por el Derecho a Decidir (the "Profesionales") ${ }^{201}$ was formalized in 2014 and comprises 500 doctors, nurses, social workers, and other public health workers who provided cost-free abortions in both private and public clinics. ${ }^{202}$ The Profesionales did not conceive of their actions as unlawful; to the contrary, the provision of abortion services prior to the IVE Law was understood by participants to be completely legal under the WHO definition of health and under the terms of the National Health Ministry's Technical Guides. ${ }^{203}$ In fact, Profesionales members counseled pregnant people seeking abortions that the procedures were indeed lawful, citing the national and international health guidelines. ${ }^{204}$

The Lesbians and Feminists for the Decriminalization of Abortion (the "Lesbians and Feminists") ${ }^{20.5}$ similarly framed their actions as lawful. Instead of citing legal documents like the Profesionales did, however, the Lesbians and Feminists group understood the legality of their actions by the very fact that abortions were being performed. ${ }^{206}$ That is, the fact that pregnant people were actually aborting and exercising this option as a matter of choice made legality a fait accompli.

Beginning in 2010, the Lesbians and Feminists published a brightlycolored handbook entitled, Everything You Want to Know About How to Perform an Abortion with Pills. ${ }^{207}$ This how-to guide was distributed on the group's website, which also housed two blogs containing information and additional resources. ${ }^{208}$ The collective of lesbians that authored the handbook destabilized the ordinary assumption that only straight women seek abortions. This reframing of the abortion issue had important impacts in the political debates that followed in 2018 and 2020. By that time, legislators were speaking not just about women seeking abortions, but inclusively, of personas gestantes ("pregnant people") or cuerpos gestantes ("pregnant bodies"). ${ }^{209}$ The public discourse surrounding abortion had

${ }^{201}$ In English, "Health Professionals for the Right to Choose." (translated into English by the author). Ruibal \& Fernandez Anderson, supra note 154, at 10.

${ }^{202}$ Id. at $10-11$.

${ }^{203}$ See, e.g., id. at 10, 12; McReynolds-Pérez, supra note 153, at 97.

${ }^{204}$ Ruibal \& Fernandez Anderson, supra note 154, at 12.

${ }^{2015}$ Sutton \& Vacarezza, supra note 139, at 742-43; Bergallo, supra note 144, at 158.

${ }^{206}$ Ruibal \& Fernandez Anderson, supra note 154, at 12. The Lesbians and Feminists' 2012 annual report declared: "Women have already decided abortion is legal." Id. (citing

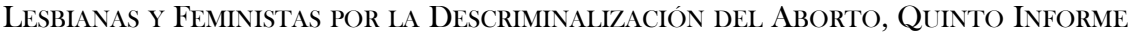
DE ATENCión de la Línea AbORTo: más Información, MENOS RIESGOS (2012) (Arg.), http://clacaidigital.info/handle/123456789/451 [https://perma.cc/RA6V-L7SQ].

${ }^{207}$ Sutton \& Vacarezza, supra note 139139, at 744-75. The text of a sidebar on the handbook's cover reads: "Easy Cheap Safe At Home!” Id. at 775.

${ }^{2018} I d$. at 743. For example, the guide included a link to the World Health Organization's website. Id.

${ }^{209}$ See Karla Pérez González \& Julieta Núñez Tomas, Cuerpos gestantes: el término pionero en Argentina para nombrar a quienes abortan, Distintas LatiTudes (Dec. 17, 2020), 
broadened to include within its imagination not just cis-gendered, straight women but also lesbians and gender non-binary people. ${ }^{210}$ And, while these direct-action services sought to provide immediate and practical access to abortion, the participation of these diverse social actors also played an important part in destigmatizing and demystifying the idea and practice of abortion across Argentinian society. ${ }^{211}$

The Campaign's multi-faceted slogan, "[s]exual education to decide, contraception no[t] to abort, legal abortion to not die" ${ }^{12}$ is emblematic of the varied methods by which reproductive justice activists pursued social change in Argentina. Article 86 of the Penal Code provided the movement with a presently available means of opening access to abortion services, but abortion by exception was not the end goal. Decriminalization and legal, safe, and cost-free abortion by election was. This goal was realized through the IVE Law of 2020.

\section{The IVE Law and the 1,000-Day Plan}

The Argentine Senate passed the IVE Law on December 30, 2020, and legal abortion became law on January 15, 2021. ${ }^{213}$ Under the IVE Law, any pregnant person over sixteen years of age may seek an abortion, without

https://distintaslatitudes.net/explicadores/cuerpos-gestantes-argentina-aborto

[https://perma.cc/5TE5-NXRU]. The Jackson Women's Health Organization Brief in Opposition also uses this non-gendered language to refer to pregnant people. See Brief in Opposition at 1, Dobbs v. Jackson Women's Health Org., 945 F.3d 265 (5th Cir. 2019), cert. granted, 141 S. Ct. 2619 (2021) (No. 19-1392) 2020 WL 5027312. ("[B]efore viability, it is for the pregnant person, and not the State, to make the ultimate decision whether to continue a pregnancy.”). This seems to be a conscientious choice because in its Amended Complaint in the District Court, the same organization restricted its discussion to pregnant “women.” See Amended Complaint at II 35, I 49, I 135, Jackson Women's Health Org. v. Currier, 349 F. Supp. 3d 536 (S.D. Miss. 2018) No. 3:18-cv-00171-CWR-FKB, 2018 WL 6120525 .

${ }^{210}$ See Aborto: por qué el proyecto se refiere a "mujeres y personas gestantes," Clakín (June 12, 2018) (Arg.), https://www.clarin.com/sociedad/aborto-proyecto-refiere-mujerespersonas-gestantes_0_B1cNbapxX.html [https://perma.cc/MVQ5-VABV]. During the 2020 Senate debate, Maximiliano Ferraro, leader of the Coalición Cívica ARI of the conservative government of former President Mauricio Macri, declared: "I believe in the expansion and recognition of rights, that is why my vote is in favor. In favor of settling the debt of democracy with women and people with gestational capacity, because we have a stake in a future where no one denies a right to anyone." Ferraro: "Esta ley busca contar con una vergüenza menos y una libertad más,” Télam (Dec. 11, 2020) (Arg.), https://www.telam.com.ar/notas/202012/538145-maximiliano-ferraro-diputados-coalicioncivica-proyecto-aborto.html [https://perma.cc/YVL3-CTNX] (emphasis added) (translated into English by the author).

${ }^{211}$ Ruibal \& Fernandez Anderson, supra note 154, at 12.

${ }^{212}$ Monte, Abortion Liberalization, supra note 109, at 1271.

${ }^{213}$ See Law No. 27610, Jan. 15, 2021, Ley del Acceso a la Interrupción Voluntaria del Embarazo [Interrupción Voluntaria del Embarazo] [IVE Law] [34.562] B.O. 3 (Arg.). 
restriction, during the first fourteen weeks of a pregnancy. ${ }^{214}$ When the pregnant person is younger than thirteen-years-old, at least one parent or the child's legal representative must provide supplemental informed consent. ${ }^{215}$ Between the ages of thirteen and sixteen, children are "presumed to have the aptitude and maturity to decide," and therefore autonomous consent is sufficient. ${ }^{216}$

Abortions under the IVE Law are fully covered medical procedures under the nation's compulsory medical plan ("PMO" for its initials in Spanish). ${ }^{217}$ Once requested, the abortion must be provided within ten days of the request. ${ }^{218}$ Although individual health care professionals may decline to provide abortion services, the IVE Law requires that conscientious objectors must refer the patient to another provider without delay. ${ }^{219}$ Failure to make timely referrals is punishable by criminal and civil sanctions. ${ }^{220}$

The IVE Law was accompanied by Law 27611, the Comprehensive Attention and Health Care During Pregnancy and Early Childhood Law, also known as the 1,000-Day Plan. ${ }^{221}$ The 1,000-Day Plan provides financial

${ }^{214}$ IVE Law, art. 8(a) (Arg.) (declaring persons above the age of sixteen have rights granted by the IVE law); Id. at art. 4 (providing unrestricted access to abortion until the fourteenth week of pregnancy); see also Tanya Wadhwa, Right to Abortion is One Step Closer to Becoming Law in Argentina, Peoples Dispatch (Nov. 20, 2020), https://peoplesdispatch.org/2020/11/20/right-to-abortion-is-one-step-closer-to-becominglaw-in-argentina/ [https://perma.cc/MK3G-DRKJ] (describing the protests which led to President Fernández sending the IVE bill and the 1000-day Plan bill to National Congress for consideration).

${ }^{215}$ IVE Law, art. 8(b) (Arg.) (cross-referencing Article 26 of the Civil and Commercial Code and the National Ministry of Health's Resolution 65/15); Ministerio DE SALud, Protocolo para la atención INTEgRAL DE LAS PERSONAS CON DERECHO A LA INTERRUPCIÓN VOLUNTARIA Y LEGAL DEL EMBARAZO 30-31 (2021) (Arg.), https://bancos.salud.gob.ar/sites/default/files/2021-05/protocolo-IVE_ILE-2021-26-052021.pdf [https://perma.cc/7AUL-FAMH] [hereinafter 2021 Protocol].

${ }^{216} 2021$ Protocol, supra note 215, at 28-29 ("All adolescents between the ages of 13 and 16 can give their consent autonomously if it involves practices that do not represent a serious risk to their life or health.”).

${ }^{217}$ Lucía Leszinsky, Abortion in Argentina: The Struggle Continues, Global Voices (Mar. 12, 2021), https://globalvoices.org/2021/03/12/abortion-in-argentina-the-struggle-continues/ [https://perma.cc/KP7V-5NVS]. The health insurance plan for the Province of Buenos Aires, IOMA, announced that it will cover 100\% of IVE procedures. 2021 Protocol, supra note 215 , at 15 .

${ }^{218}$ IVE Law, art. 5 (Arg.).

${ }^{219}$ Id. at art.10-11.

${ }^{220} I d$. at art. $10(\mathrm{c})$.

${ }^{221}$ See Law No. 27611, Jan. 15, 2021, Ley Nacional de Atención y Cuidado Integral de la Salud Durante el Embarazo y la Primera Infancia [Salud Durante el Embarazo y la Primera Infancia] [1,000-Day Law] [34.562] B.O. 8 (Arg.). The 1,000-Day Plan passed by unanimous votes in both houses of Congress. El Senado convirtió ley el Plan de los 1.000 Días de asistencia a niños y niñas, TéLAM (Dec. 30, 2020) (Arg.), https://www.telam.com.ar/notas/202012/540048-convierten-en-ley-el-plan-de-los-1000-diasde-asistencia-a-ninos-y-ninas.html [https://perma.cc/AH68-VJC4]. 
assistance for pregnant persons during the entire pregnancy through nine monthly payments ${ }^{222}$ and for children up to the age of three through a universal child allowance. ${ }^{223}$ Pregnant persons and young children are also eligible to receive free medicines, vaccines, milk, and food through the Plan. ${ }^{224}$ The purpose of the 1,000-Day Plan is to lower childhood mortality and malnutrition as a means of preventing violence and to support emotional and physical development. ${ }^{225}$

Anti-abortion actors immediately filed legal challenges to the IVE Law in over half of the country's twenty-three provinces ${ }^{226}$ As of June 2021, antiabortion groups had filed a total of twenty-nine submissions of various kinds in national and provincial courts throughout the country, but eighteen of those had already been rejected, while the rest are pending final resolution. ${ }^{227}$ It still remains to be seen what the practical result of these legal challenges to the national IVE Law will be, but the remainder of this Article evaluates the depth of the culture shift regarding abortion as a social issue in Argentina and ends by forecasting that, because the legislative reforms reflected rather than preceded significant progressive social change, the IVE Law will be able to withstand any judicial challenges it may confront. If the U.S. Supreme Court overrules Roe v. Wade, it may be time for United States-based abortion rights activists to more closely study the Argentine experience.

\section{Does Argentina RePresent the Alternate REALity CONTEMPLATED BY JUSTICE GINSBURG?}

The recent decision of the U.S. Supreme Court to grant certiorari in the Dobbs case demonstrates how precarious abortion rights in the United States actually are. Justice Amy Coney Barrett, who replaced Justice Ginsburg on the Court, has been publicly forthright about her personal opposition to abortion. ${ }^{228}$ Many commentators have observed that the Court

${ }^{222}$ 1,000-Day Law, art. 7 (Arg.).

${ }^{223} \mathrm{Id}$. at art. 3, 5.

${ }^{224} I d$. at art. 20.

${ }^{225}$ Jefatura de Gabinete de Ministros, Ley de Interrupción Voluntaria del Embarazo y Plan de los 1000 días, República Argentina (Feb. 12, 2021), https://www.argentina.gob.ar/noticias/ley-de-interrupcion-voluntaria-del-embarazo-y-plande-los-1000-dias [https://perma.cc/SWG6-T7MG]; see also 1,000-Day Law, art 1 (Arg.).

${ }^{226}$ Daniel Politi, Abortion is Now Legal in Argentina, Opponents Make It Hard to Get, N.Y. Times, Mar. 7, 2021, at A10.

${ }^{227}$ Ministerio de Justicia y Derechos Humanos, INADI Mar del Plata: rechazo por el fallo contra la ley del aborto, República Argentina (June 8, 2021), https://www.argentina.gob.ar/noticias/inadi-mar-del-plata-rechazo-por-el-fallo-contra-la-leydel-aborto [https://perma.cc/9UJ8-4H8L].

${ }^{228}$ Adam Liptak, Amy Coney Barrett, Trump Supreme Court Pick, Signed Anti-Abortion $A d$, N.Y. Times (Oct. 1, 2020), https://www.nytimes.com/2020/10/01/us/amy-coney-barrett- 
now has the conservative majority necessary to overturn Roe. ${ }^{229}$ If that happens, the United States will return to a system where the patchwork of state laws will determine who is permitted to access abortion services and who is not. Mississippi and nine other states led by conservative legislators have already passed "trigger laws" that will replace current abortion regulations with abortion bans, in the event that the Supreme Court overturns Roe. ${ }^{230}$ The current legal abortion regime in the United States already operates in a manner that disfavors younger, poorer women, especially women of color. ${ }^{231}$ Poor people will always bear the unequal burden of laws restricting abortion access, a truth which is experienced throughout the world. ${ }^{232}$ To be clear, pregnant people will not stop seeking abortion to end unwanted pregnancies, but restricted access to safe abortion services and post-abortion care will put their lives and health in grave danger. ${ }^{233}$

In some ways, the Argentine IVE Law presents an alternate reality to the current legal quandary around abortion access in the United States. Both of the concerns raised by Justice Ginsburg seem to have been anticipated, addressed, and resolved by the reproductive justice movement in Argentina during the campaign to decriminalize abortion. This Article argues that the Campaign activists succeeded in changing cultural norms about abortion and reproductive justice in Argentina in such a way that predicts that

abortion.html [https://perma.cc/Y82E-D5GB]. In 2006, Justice Barrett signed her name to an advertisement placed in the South Bend Tribune by a pro-life group now known as Right to Life Michiana. Id. The ad said, in part: "it's time to put an end to the barbaric legacy of Roe v. Wade and restore laws that protect the lives of unborn children." Id. She was a member of the Notre Dame law faculty at the time. Id.

${ }^{229}$ Amy Howe, Roe v. Wade Hangs in Balance as Reshaped Court Prepares to Hear Biggest Abortion Case in Decades, SCOTUSblog (Nov. 29, 2021, 8:00 AM), https://www.scotusblog.com/2021/11/roe-v-wade-hangs-in-balance-as-reshaped-courtprepares-to-hear-biggest-abortion-case-in-decades/ [https://perma.cc/V2FQ-N7WD] ("During his four years in office, Trump placed three justices - Neil Gorsuch, Brett Kavanaugh, and Amy Coney Barrett - on the court, cementing a 6-3 conservative majority. With that majority in place, conservatives hope, and liberals fear, that the court will renounce nearly five decades of abortion jurisprudence and overturn the landmark rulings of Roe $\mathrm{v}$. Wade and Planned Parenthood v. Casey. In Dobbs v. Jackson Women's Health Organization, which is scheduled for oral argument on Wednesday, the justices have been asked to do just that.").

${ }^{230}$ See, e.g., Idaho CODE $\$ 18-622$ (2020); Miss. CODE Ann. \$ 41-41-45 (2018).

${ }^{231}$ Bridges, supra note 32; Khiara M. Bridges, The Poverty of Privacy Rights (2017).

${ }^{232}$ See, e.g., Gillian Kane, Abortion Reform in Latin America: Lessons for Advocacy, 16 GENDER \& DEv. 361, 361 (2008); Ramos et al., supra note 122 (arguing that without legal abortion, only women with financial means will be able terminate their pregnancies, making abortion access "a question of purchasing power").

${ }^{233}$ See Sarah Parvini, Argentina Bans Abortion in Most Cases. So Why Is its Abortion Rate Far Higher than That of the U.S.P, L.A. Times (Oct. 29, 2017),

https:/www.latimes.com/world/mexico-americas/la-fg-argentina-abortion-20171029-

htmlstory.html [https://perma.cc/C65V-E5QF] (stating abortion rates are higher in Argentina than the United States). 
litigation challenges that already have and will continue to be filed in the court system will likely fail. It uses the culture-shifting framework to articulate the reasons why.

Before his death in $1997,{ }^{234}$ NYU Law Professor Thomas B. Stoddard wrote an essay entitled Bleeding Heart in which he argued that social justice lawyers should focus their efforts on winning legislative reform because majoritarian political victories are more likely to lead to enduring culture shifts than are reforms won through litigation in the courts. ${ }^{235}$ As compared to rule-shifting where the impact is felt mostly in formal changes to the black-letter law, Stoddard argued that the culture-shifting power of the law is most potent when it sets about transforming social norms at the ground level in ways that people actually live and experience. ${ }^{236}$

Stoddard's primary example of culture shifting was the Civil Rights Act of 1964. For Stoddard, the change in public attitudes and cultural norms was a necessary prerequisite to the majoritarian politics that delivered the congressional act. The Civil Rights Act was not the starting point, but rather the result of "a continuing passionate and informal national debate of at least a decade's duration" culminating in passage by Congress. ${ }^{237}$ Stoddard found evidence of this culture shift in changed social norms and expectations during this era, specifically, in the widely-shared social judgment that de jure racial segregation is bad public policy. ${ }^{238} \mathrm{He}$ credited this change in social attitudes to the political processes inherent in legislative work. For Stoddard, "[l]egislative reform makes real change-'culture shifting'-more probable, since it is more likely than other forms of lawmaking to engage the attention of the public." ${ }^{239}$

Stoddard's culture-shifting paradigm is responsive to Justice Ginsburg's argument that Roe stunted the public conversation about abortion in the United States. It is also in line with a larger body of work

${ }^{234}$ David W. Dunlap, Thomas Stoddard, 48, Dies; An Advocate of Gay Rights, N.Y. TIMEs, Feb. 14, 1997, at B6.

${ }^{235}$ See Thomas B. Stoddard, Bleeding Heart: Reflections on Using the Law to Make Social Change, 72 N.Y.U. L. REv. 967, 991 (1997). See id. at 972. "Attempts to reform the law may succeed as a formal matter but have only modest effects on the larger cultural context into which they fit." Id.

${ }^{236}$ See id. at $972-73$.

${ }^{237} I d$. at 976 . Stoddard was not pollyannish about the Civil Rights Act; he conceded that the law did not end discrimination or racism. Id. at 975 . He may have overlooked, however, the external geopolitical pressures that also contributed to the end of de jure racial discrimination. See Derrick A. Bell, Jr., Brown v. Board of Education and the InterestConvergence Dilemma, 93 HaRv. L. REv. 518 (1980) (hypothesizing that minoritized racial groups gain ground on equal civil rights only when their interests align with those of the dominant White majority); Mary L. Dudziak, Desegregation as a Cold War Imperative, 41 STAN. L. Rev. 61, 66 (1988) (proving Bell's hypothesis while demonstrating that racial desegregation in the United States was largely a product of Cold War politics).

${ }^{238}$ Stoddard, supra note 235 , at 974 .

${ }^{239}$ Id. at 982 . 
that argues that courts cannot be nor should they be the main mechanisms for bringing about the "full realization of constitutional ideals." ${ }^{210}$ Lani Guinier and Gerald Torres, for example, have used the word "demosprudence" ${ }^{241}$ to describe the notion that social movements and political activism are critical components of social change and contribute to the culture shifts that make that change lasting. ${ }^{242}$ Guinier and Torres's ideas about demosprudence are also related to what Verónica Gago calls "embodied knowledge production," or the praxis of social movements, which in and of itself challenges divisions between the intellectual and the activist and implies informal ways of producing social change. ${ }^{243}$ Like Stoddard, these thinkers consider social norms to be a product of the mutual construction of legal elites and "ordinary people."24

Gago's observation about embodied knowledge production of the type witnessed around reproductive justice demands in Argentina urges that social change can result from extra-legal strategies and modalities. That is, reformers can and should look outside the law to effect change. Ultimately, what this all means is that advocates for social change should prioritize advocacy work that, regardless of modality, will speak directly to the broader public. $^{215}$

The culture-shifting paradigm presents a measure by which to evaluate Argentina's progress towards reproductive justice through its IVE Law. For culture-shifting to take place, Stoddard prescribed that the legal reform must

\footnotetext{
${ }^{20}$ McClain, supra note 61, at 601-02; Mark Tushnet, TAKIng The Constitution Away FROM THE COURTS (1999)).

${ }^{211}$ See, e.g., Lani Guinier, Foreword: Demosprudence Through Dissent, 122 Harv. L. Rev. 4 (2008) (debuting the notion of demosprudence through examining how dissenting Justices in the Supreme Court engage the public through the use of oral dissents); Lani Guinier \& Gerald Torres, Changing the Wind: Notes Towards a Demosprudence of Law and Social Movements, 123 Yale L.J. 2740 (2014) (reviewing Bruce Ackerman, WE THE People: The Civil Rights Revolution (2014)).

${ }^{212}$ Guinier \& Torres, supra note 241, at 2723. As Torres explains, demosprudence is "a philosophy, a methodology and a practice that systematically views lawmaking from the perspective of popular mobilizations, such as social movements and other sustained forms of collective action that serve to make formal institutions, including those that regulate legal culture, more representative and thus more democratic." Gerald Torres, Legal Change, The Eighty-Third Cleveland-Marshall Fund Visiting Scholar Lecture, 55 CLEv. ST. L. REv. 135, 135-36 (2007).

${ }^{213}$ Verónica Gago \& Liz Mason-Deese, Rethinking Situated Knowledge from the Perspective of Argentina's Feminist Strike, 18 J. LATin AM. Geography 202, 203 (2019). Gago uses a transformative definition of "informal." "The informal in this sense does not refer to that without a form but to the dynamic that invents and promotes (productive, commercial, relational, etc.) forms, focusing on the process of producing new social dynamics." Verónica Gago, Neoliberalism from Below: Popular Pragmatics and Baroque ECONOMIES 15 (2017).

${ }^{24}$ Lani Guinier, Courting the People: Demosprudence and the Law/Politics Divide, 89 B.U. L. REV. 539, 545 (2009).

${ }^{215}$ See Nan Hunter, Lawyering for Social Justice, 72 N.Y.U. L. REv. 1009, 1011 (1997).
} 
be characterized by four things: (1) breadth of change; (2) public awareness; (3) a general sense of the legitimacy of the change; and (4) overall, continuous enforcement. ${ }^{246}$

\section{A. Breadth of Change}

The first prerequisite for a culture-shifting law is that the change augured by it be "very broad or profound." ${ }^{277}$ For instance, the scope of a new law might be "so grand or so pervasive" that the shift in the legal framework is undeniable. ${ }^{218}$ Roe $\mathrm{v}$. Wade and the IVE Law both meet that breadth standard, because both completely upended the previously existing legal order. Nevertheless, breadth of change from a rule-shifting perspective does not always mean a corresponding culture shift in the hearts and minds of the public impacted by the new legal rules. Stated otherwise, breadth of change, like each of the three other elements of Stoddard's framework, is not sufficient on its own to produce a meaningful culture shift. This Article has argued that Roe $v$. Wade did not make an immediate shift to a general pro-choice culture, nor did it reflect a contemporary culture shift when it was decided in 1973. Here, the Article takes up the argument that, in contrast to Roe, the IVE Law was the result of decades of political activism whose work was to change the social and cultural meaning of abortion. The Campaign changed the terms of the abortion debate, framing the issue not as merely one of individual sexuality and privacy, but one of public health and human rights (i.e., equality). It was only after this cultural shift in general society had been achieved that the Argentine Congress could pass the landmark legislative reform.

The breadth of change in Argentina was accomplished by decades of perseverance and commitment to a feminist politics that changed the social meaning of abortion. In part, this meant drawing a private and taboo medical procedure out of the shadows and into public view. As Senator Lucila Crexell described: "We managed to break the prejudice, and the discussion became a lot less dramatic. Society at large started to understand the debate in more moderate, less fanatic terms." ${ }^{219}$ Efforts to do exactly this were intentional and drew on many lessons from international experiences in rights advocacy, including those learned from the United States.

A massive collective of activists with a staunchly feminist orientation demanded the right to legal, safe, and cost-free abortion in Argentina and secured it. Argentina's reform based on decades of feminist activism and

\footnotetext{
${ }^{216}$ Stoddard, supra note 235 , at 978 .

${ }^{217} I d$.

${ }^{218} I d$.

${ }^{219}$ Daniel Politi \& Ernesto Londoño, How Support for Legal Abortion Went Mainstream in Argentina, N.Y. Times, Jan. 1, 2021, at A9. [hereinafter Politi \& Londoño, How Support Went Mainstream].
} 
organizing, not unlike the experience in other Latin American countries. ${ }^{250}$ Feminist-oriented activism meant that the movement deliberately constructed a politics around the constellation of equality, autonomy, social justice, public health, and human rights. ${ }^{251}$ The creation of a widespread and sophisticated public discourse around these guiding principles proved to be another key move. In its evolution, the movement for abortion rights in Argentina utilized a variety of discursive frames to advance its agenda, before eventually settling on the public health and human rights framework that is found in the text of the IVE Law. ${ }^{252}$ The significant change in the ways of thinking about abortion is what truly marks the breadth of change that Stoddard believed to be essential for a culture shift.

In 1973, privacy may have provided a conceptual through-line from contraceptives to abortion in United States' jurisprudence, but the privacy rationale did not acknowledge nor correct the sex- and gender-based inequities of restrictive abortion laws. To be clear, abortion restrictions demean women and others with gestational capacity because they displace the woman's autonomy with the state's political preferences. This is a level of state intrusion that simply does not exist when it comes to the exercise of any other fundamental rights. ${ }^{253}$ While on the Court, Justice Ginsburg attempted to carve a path from privacy to equality, explaining: "legal challenges to undue restrictions on abortion procedures do not seek to vindicate some generalized notion of privacy; rather, they center on a woman's autonomy to determine her life's course, and thus to enjoy equal citizenship stature." ${ }^{254}$ Judge Reeve's district court opinion in Dobbs followed this path, but the equality rationale has not yet been adopted by a majority of the U.S. Supreme Court.

Argentinian advocates were keenly aware of the shortcomings of the United States' approach to abortion rights as framed solely through a right of privacy. From a strategic standpoint, the Campaign benefitted from observing at a distance the jurisprudential and political weaknesses of the United States experience in grounding reproductive justice concerns in privacy. The lessons were explicit. As one lawyer and a member of the Argentinian pro-choice organization Catholics for Choice articulated: "I think that in [1973, it] was not so clear [from] feminisms in the United States

\footnotetext{
${ }^{250}$ Kane, supra note 232, at 366-67 (noting that more liberalized abortion access laws in Colombia and in Mexico City were built on decades of activism in the women's movement). ${ }^{2: 1}$ Sutton \& Vacarezza, supra note 139, at 750-51 (connecting abortion rights to human rights and social justice, a topic particularly salient in post-dictatorship Argentina). Campaign slogan: "Legal Abortion, a Debt of Democracy." Id. at 751. Campaign slogan: "Unsafe Abortion Never Again," recalls the "Nunca Más" or "Never Again” title of the 1984 official governmental report on the desaparacidos ("the disappeared") during the military dictatorship. Id.

${ }^{252}$ Id. at 732.

${ }^{253}$ See Rebouché \& Mutcherson, supra note 37, at 166.

${ }^{25 i}$ Gonzales v. Carhart, 550 U.S. 124, 172 (2007) (Ginsburg, J., dissenting).
} 
... that privacy was not enough." ${ }^{255}$

In the years before the military dictatorship, access to lawful abortion was discursively tied to the broader women's liberation movement. ${ }^{256}$ In the years after Roe, the privacy rationale had been evaluated and found wanting. In the 1980s and 1990s, feminists around the world began to speak of abortion not as a consequence of individual sexuality, but as an issue of social justice. The reproductive justice movement in Argentina rejected privacy as the basis for abortion rights, turning instead to the notion of public health care as a human right. ${ }^{257}$ This discursive shift also heralded a change in political tactics; as discussed previously, reproductive rights groups had now turned to litigating abortion access under Article 86 of the Penal Code as rights-based claims in the courts. ${ }^{258}$ The visual images that depicted the movement also changed during this time, moving from gruesome images of women as objects suffering from clandestine abortions to images of politicized women as autonomous subjects making demands of the state to protect reproductive freedoms. ${ }^{259}$

The potency of this discursive shift had material impacts in the form of the 2020 IVE Law. Senator Silvina García Larraburu voted against legalization in 2018, but in 2020 articulated the reasons for her change of heart: "We're going through a shift in paradigm, and this change is led by the feminist and environmental fights. Beyond my personal position, of my beliefs, we are faced with a problem that requires a public health approach." 260

In Argentina, the right to choose abortion under the IVE Law is considered a human right based in the constitutional principle of equality. ${ }^{261}$ The equality principle is embedded in the text of the IVE Law itself, with explicit reference to provisions in the national constitution and to various international and regional human rights treaties. ${ }^{262}$ International agreements such as the Universal Declaration of Human Rights, the Convention Against

\footnotetext{
${ }^{2,5}$ Monte, Abortion Liberalization, supra note 109, at 1277 (quoting an interview subject).

${ }^{256}$ Politi \& Londoño, How Support Went Mainstream, supra note 249.

${ }^{257}$ Monte, Abortion Liberalization, supra note 109, at 1270.

${ }^{258}$ Id. at 1264 (procedurally, the litigation route was also made possible by constitutional reforms in 1994).

${ }^{259}$ Sutton \& Vacarezza, supra note 139, at 736.

${ }^{260}$ Politi \& Londoño, How Support Went Mainstream, supra note 249.

${ }^{261}$ See Law No. 27610, art. 3, Jan. 15, 2021, Ley del Acceso a la Interrupción Voluntaria del Embarazo [Interrupción Voluntaria del Embarazo] [IVE Law] [34.562] B.O. 3 (Arg.) (citing, inter alia, Art. 75, para. 22, CONSTITUCiÓN NACIONAL [CONST. NAC.] (Arg.); international human rights instruments including the Universal Declaration of Human Rights, the Convention for the Elimination of All Forms of Discrimination Against Women, the InterAmerican Convention on the Prevention, Punishment, and Eradication of Violence Against Women, and the Convention Against Torture; and the right to substantive equality of opportunity).

${ }^{262}$ Id. International treaty law is supreme over domestic law. Art. 75, para. 22, CONSTITUCIÓN Nacional [COnst. NaC.] (Arg.).
} 
All Forms of Discrimination Against Women, the Inter-American Convention on the Prevention, Punishment, and Eradication of Violence Against Women, and the Convention Against Torture complement the principles of substantive equality of opportunity contained at various points in the Argentine Constitution. ${ }^{263}$ From the perspective of the IVE Law, equality and autonomy are interconnected. One of the Campaign's slogans encapsulated this notion: la maternidad será deseada o no será (in English, "motherhood will be desired or it will not be"). ${ }^{264}$ The framing of abortion access as a human right that implicates social justice and public health was a deliberate move propagated by Campaign activists.

Over time and in multiple sites of contestation, the Campaign successfully debated, educated, and mobilized thousands of women and others to support the mass movement to legalize abortion. The movement relied on the coalition of many and varied organizations, and the feminist force behind it has had political impacts beyond the abortion issue, from bringing awareness and action to the femicide crisis and aiding in trans liberation.

\section{B. Public Awareness}

Public awareness is the second prerequisite of the culture-shift framework. For a law to have a culture-shifting effect, it is almost axiomatic that those impacted by the new rule know or at least be aware of its existence. ${ }^{265}$ For Stoddard, legislative lawmaking is far more likely than judicial lawmaking to result in the public becoming aware of the issue(s) at stake because of the political nature of legislatures. ${ }^{266}$ "Indeed, the real significance of some forms of legislative lawmaking lies in the debate they engender rather than the formal consequences of their enactment." ${ }^{267}$ Justice Ginsburg shared Stoddard's perspective about the public nature of legislative lawmaking, thus her animadversion for the way the Court handled

${ }^{263} I d$. at art. 75, para. 22. For example, Congress has the power " $[\mathrm{t}]_{\mathrm{o}}$ legislate and promote proactive measures that guarantee true equality of opportunity and treatment, and the full enjoyment and exercise of the rights recognized by this Constitution and by current international treaties on human rights, in particular with respect to children, women, the elderly and people with disabilities. [Congress is further empowered t ] $_{0}$ enact a special and integral social security system that protects needy children, from gestation through the end of elementary schooling, and that protects the mother during pregnancy and nursing." Id. at art. 75, para. 23, translated in ARGENTINA's CONSTITUTION OF 1853, REINSTATED IN 1983, with Amendments through 1994, Constitute Project 19 (Aug. 21, 2021, 4:17 PM), https://www.constituteproject.org/constitution/Argentina_1994.pdf?lang=en [https://perma.cc/J94Z-J2FJ].

${ }^{26}$ The direct translation is noted in the text above, but the slogan's actual meaning is closer to: "Motherhood should be desired and chosen, not imposed." (translated into English by the author).

${ }^{265}$ Stoddard, supra note 235 , at 978.

${ }^{266}$ Id. at 930-31.

${ }^{267}$ Id. at 931 . 
the Texas abortion ban in Roe.

By contrast, the IVE Law was passed by the majority of both houses of the Argentine Congress after lengthy debates. ${ }^{268}$ The lower chamber debated for twenty hours before a close vote moved the bill to the Senate. ${ }^{269}$ The Senate debate carried on for over twelve hours, into the early morning hours of the following day when the vote was called at 4:04 a.m. ${ }^{270}$ Eight minutes later, the final vote count read thirty-eight in favor and twenty-nine opposed, with one abstention. ${ }^{271}$ For purposes of comparison, the last time the issue had been voted on in August 2018, the measure narrowly failed in the Senate, by a vote of thirty-eight to thirty-one. ${ }^{272}$ On both occasions, Congress acted with thousands of Argentinians, mostly women wearing green, serving witness, watching and waiting outside on the streets. In 2020, when the vote was announced to the crowd, a brief hush was followed by a deafening cheer accompanied by music played over the loudspeakers set up for the occasion. ${ }^{273}$ Those who did not personally witness the vote on the streets of Buenos Aires watched from the Senate livestream, made available

${ }^{268}$ Laura Serra, Diputados le dio media sanción a la legalización del aborto y ahora se define en el Senado, LA NACIÓN (Dec. 11, 2020, 9:19 AM) (Arg.), https://www.lanacion.com.ar/politica/avanza-diputados-proyecto-legalizar-abortonid2536815 [https://perma.cc/PFW6-G4YE]. In the lower chamber, the vote was 131 in favor, 117 against, with 6 abstentions. Tras una crucial votación, se le dio media sanción al proyecto de despenalización del aborto, Diputados Argentina (June 14, 2018), https://www.hcdn.gob.ar/prensa/noticias/2018/despenalizacion-aborto/noticias_0593.html [https://perma.cc/95R3-W3SB]. In 2018, the House vote was 129 in favor, 125 against, with 1 abstention.

${ }^{269}$ Analia Argento, Tras 20 horas de debate y con 131 votos a favor y 117 en contra, Diputados le dio media sanción al proyecto de legalización del aborto, INFOBAE (Dec. 11, 2020), https:/www.infobae.com/politica/2020/12/11/tras-20-horas-de-debate-y-con-131votos-a-favor-y-117-en-contra-diputados-le-dio-media-sancion-al-proyecto-de-legalizaciondel-aborto/ [https://perma.cc/D6DZ-265J].

${ }^{270}$ Aborto legal: el debate en el Senado minuto a minuto, PáGINa 12 (Dec. 30, 2020) (Arg.), https://www.pagina12.com.ar/314277-aborto-legal-el-debate-en-el-senado-minuto-a-minuto [https://perma.cc/3LWF-RR63].

${ }^{271}$ The remaining four of seventy-two total senators were absent from the vote.

Aborto legal: cómo votó cada senador, PÁGINA 12 (Dec. 30, 2020) (Arg.), https://www.pagina12.com.ar/314448-aborto-legal-como-voto-cada-senador [https://perma.cc/RV8R-F4HD].

${ }^{272}$ Mar Centenera \& Federico Rivas Molina, El Senado de Argentina dice 'no' al aborto y deja al país con una ley de 1921, EL País (Aug. 9, 2018) (Spain), https://elpais.com/internacional/2018/08/08/argentina/1533714679_728325.html [https://perma.cc/X7UZ-VK95]; see Politi \& Londoño, Argentina Legalizes Abortion, supra note 130 .

${ }^{273}$ See Politi \& Londoño, Argentina Legalizes Abortion, supra note 130 (describing the celebratory moments after the vote was announced); Ollie Vargas (@OVargas52), TwITTER (Dec. 30, 2020, 2:05 https://twitter.com/ovargas52/status/1344192875421192192?lang=en [https://perma.cc/74XT-4A36]. 
to viewers tuning in throughout the world. ${ }^{274}$

The IVE Law certainly meets the public awareness element, not only because of the presence of the Campaign on the days of the crucial votes in Congress but because of its active presence in Argentine society for years leading up to the 2020 vote. Because of the Campaign's persistence and high visibility, there was no way for society to ignore the abortion issue. It bears repeating that the legislative debate about the abortion law went through two full rounds of debate before the ultimate victory for the Campaign in 2020. But the story of how Argentina achieved the right to abortion goes even further back.

The Campaign's progenitors in both politics and iconography were the Madres de la Plaza de Mayo. ${ }^{275}$ The green pañuelo of the Campaign is an homage to the white pañuelos worn on the heads of the Madres (in English, "Mothers") as they marched silently in front of the Casa Rosada presidential palace. ${ }^{276}$ The Madres' weekly marches were originally organized to demand justice and accountability for those disappeared by the military dictatorship. ${ }^{277}$ Over time, the Madres broadened the scope of their activism, using their platform to draw public attention to various social issues-to protest neoliberal economic reforms, for example. ${ }^{278}$ The Madres also became part of the broad coalition organized by the Campaign. ${ }^{279}$ This action is significant because it marks two important moves.

One, the Madres became activists because of their identity and association as mothers of children. This is likely why their movement resonated so deeply with the Argentine people; mothers and children are traditional, sympathetic figures. ${ }^{280}$ Support for the legalization of abortion from the Madres reinforced an important message of the reproductive justice movement represented by the Campaign. That is, access to legal, safe, and free abortion is not diametrically opposed to motherhood, but rather enhances it. ${ }^{281}$ Indeed, many women who seek abortions are already mothers who want to conserve their limited emotional and financial

${ }^{271} I d$.

${ }^{275}$ See Sutton \& Vacarezza, supra note 139, at 740.

${ }^{276} I d$. (locating the origin of the green pañuelo or handkerchief, ubiquitous symbol of the Campaign, in the white handkerchief that the Mothers wore on their heads).

${ }^{277}$ Kim D. Chanbonpin, Truth Stories: Credibility Determinations at the Illinois Torture Inquiry and Relief Commission, 45 LOYOLA U. CHI. L.J. 1085, 1134 (2014).

${ }^{278} I d$.

${ }^{279}$ Abuelas y Madres de Plaza de Mayo apoyaron la legalización del aborto, El DeSTAPE (June 12, 2018) (Arg.), https://www.eldestapeweb.com/nota/abuelas-y-madres-de-plaza-demayo-apoyaron-la-legalizacion-del-aborto-2018-6-12-11-27-0 [https://perma.cc/N5XH3PP6].

${ }^{280}$ Colleen McCormack, The Madres de Plaza de Mayo: Motherhood's Search for Answers During the Dirty War in Argentina, Northwest Passages (2014), https://pilotscholars.up.edu/cgi/viewcontent.cgi?article=1005\&context=nwpassages [https://perma.cc/SN84-VGFP].

${ }^{281}$ Sutton \& Vacarezza, supra note 139 , at 741. 
resources for their existing children. ${ }^{282}$ The Madres' support affirmed that the Campaign was not anti-motherhood but instead, recognized that forced motherhood is a type of gendered violence. ${ }^{283}$

Two, by joining the Campaign, the Madres were passing a symbolic baton in the lineage of feminist and women-centered grassroots social movements in Argentina. The green pañuelo and its inherent connection with the Madres is visible proof of this genealogy. In fact, the green pañuelo features a stylized image of a white ribbon that is a visual nod to the iconic Madres. ${ }^{284}$ The Campaign began using green pañuelos as a symbol of the reproductive justice movement in 2003 at the annual Encuentro National de Mujeres (in English, "National Meeting of Women”), during a special assembly on abortion. ${ }^{285}$ The Encuentros began meeting each year in 1986 and were critical to developing the popular discourse about abortion as a public health and human rights issue. ${ }^{286}$ These annual meetings were held in different provinces each year to disrupt the idea that all activism began in the capitol, and distributing power and presence in this way was key to building capacity and movement strength. ${ }^{287}$ The Encuentros made space for women of different ages and racial, class, and political backgrounds to discuss the still-taboo topic of abortion. ${ }^{288}$ The Campaign itself was a product of the nineteenth annual Encuentro in Mendoza, one year after the green pañuelos first appeared. ${ }^{289}$

The green pañuelo is not just a fashion statement; over time, the color green became generative. ${ }^{290}$ Campaign green became meaningful because of repeated use by the ever-growing numbers of supporters displaying it, immediately communicating a political message. ${ }^{291}$ The green pañuelos became so popular that vendors outside the Congress began to sell them to crowds gathered for the mass demonstrations and tourists alike. ${ }^{292}$ The

${ }^{282} I d$.

${ }^{293}$ Id. at $740-41$.

${ }^{284}$ Id. at 740 .

${ }^{285}$ Barbara Sutton \& Elizabeth Borland, Framing Abortion Rights in Argentina's Encuentros Nacionales de Mujeres, 39 Feminist Studies 194, 195, 201 (2013).

${ }^{286} I d$. at 195.

${ }^{287} I d$.

${ }^{288}$ Cf. Murray, supra note 23, at 2053 (spotlighting the women of color, queer women, poor, and disabled people that founded the reproductive justice movement in the United States, introducing an intersectional approach to abortion access that also condemned forced sterilization and eugenics, as a counterpoint to the reproductive rights movement headed primarily by white women).

${ }_{229}^{28}$ María Florencia Alcaraz, Nuestro derecho es ley, Revista Anfibia (Dec. 30, 2020) (Arg.), http://revistaanfibia.com/cronica/nuestro-derecho-es-ley/ [https://perma.cc/59VC-LQ49].

${ }^{200}$ See Monte, Abortion Liberalization, supra note 109, at 1271.

${ }^{201}$ Sutton \& Vacarezza, supra note 139 , at 742.

292 Remeras, pañuelos y muñecas de trapo se venden en la Plaza del Congreso durante la vigilia, 
vendors capitalized on the popularity of the pañuelo but also effectively aided the Campaign in disseminating its symbolic message. The iconography of the green pañuelo has also transcended national borders, becoming a shared emblem of abortion rights and feminist movements throughout Latin America and the world. ${ }^{293}$

Campaign green is a symbol of the legal abortion movement, but it also has its place in dialogue within and among broader feminist struggles. As is often repeated, the Campaign is a transversal (or in language more familiar to United States observers, an intersectional) movement. If antecedents of the reproductive justice movement in Argentina are the Madres, then Ni Una Menos is her tech-savvy younger sister. The Campaign was officially launched in 2004 and certainly grew in size and prominence since that time, but $\mathrm{Ni}$ Una Menos was undeniably the catalyst in the national debate about gender violence, women's rights, and legal abortion. ${ }^{294}$ In the words of journalist and Campaign historian Flor Alcaraz, there was "a before and an after" Ni Una Menos. ${ }^{295}$

Ni Una Menos (in English, "Not One Less") is another grassroots movement that emerged as a result of the femicide crisis in Argentina and in other countries in Latin America. ${ }^{296}$ The first Ni Una Menos march was organized in 2015 and drew 500,000 across the country. ${ }^{297}$ The sheer volume of Ni Una Menos made it powerful and it displayed that power by coordinating yearly feminist strikes. ${ }^{298}$ The mass media, television in particular, paid attention to the feminist movements. ${ }^{299}$ Media followed the public in this regard. Television aired these discussions because thousands were tuning in. Feminist activists were invited to speak on a popular daytime

TÉLAM (June 13, 2018) (Arg.), https://www.telam.com.ar/notas/201806/289752-remeraspanuelos-y-munecas-de-trapo-se-venden-en-la-plaza-del-congreso-durante-la-vigilia-por-laley-del-aborto.html [https://perma.cc/9NLL-HFUL].

${ }^{203}$ See Phoebe Martin, The 'Pañuelo Verde' Across Latin America: A Symbol of Transnational and Local Feminist (Re)volution, King's College London (Sept. 17, 2020), https://www.kcl.ac.uk/the-panuelo-verde-across-latin-america [https://perma.cc/9RELK2J4].

${ }^{2 n}$ See Politi \& Londoño, How Support Went Mainstream, supra note 249; Verónica Gago \& Raquel Gutíerrez Aguilar, The Feminist Strike as Threshold, 14 NEw GLob. STUd. 111, 113 (2020) (noting the importance of the Ni Una Menos movement but situating that movement within the decades of feminist activism in Argentina).

${ }^{205}$ María Florencia Alcaraz, ¡Que sea ley!: La luCha de los Feminismos POR EL ABORTO LEGAL (2018).

${ }^{296}$ Cecilia Palmeiro, Ni Una Menos and the Politics of Translation, 6 SPHeres J. 1, 3-4 (2020).

${ }^{207} I d$. at 5 . This number includes 300,000 people gathered in the capitol city of Buenos Aires and 200,000 others in affiliated demonstrations throughout Argentina. Id.

${ }^{208} I d$.

${ }^{299}$ Agustina Santomaso, From the Underground to the Mainstream, JACOBIn (Nicolas Allen trans.) (Apr. 25, 2018), https://www.jacobinmag.com/2018/04/argentina-abortion-feminismni-una-menos [https://perma.cc/XW95-DEWE] (telling the story of how a daytime television show's theme week on feminism encouraged other media outlets to begin covering abortion). 
television show to articulate and to publicize the many facets of their movement, and people tuned in. ${ }^{300}$ For Argentine novelist Claudia Piñeiro, "[w] hat happened with the movement [after Ni Una Menos] is that it started increasing in number and gaining different voices." others who were the face of Ni Una Menos wore purple lipstick with their green pañuelos. ${ }^{302}$ The meaning transported by the green pañuelo was deepening, becoming a symbol in pursuit of a new social norm-the valuing of women's lives. Ni Una Menos served as a bridge between causes, connecting the gendered violence of femicide to the gendered violence of unwanted pregnancies and clandestine abortions. ${ }^{303}$

Not just the public, but also politicians were aware of the Campaign's organizational and ideological lineage, as evidenced by their public remarks. For example, Senator Maximiliano Ferraro noted that the right to abortion access "is part of the historical journey of the women's movement" during his debate speech on the Senate floor. ${ }^{304}$ Ferraro was the leader of a coalition caucus under the conservative government of former President Mauricio Macri, but he had been moved by the arguments presented by the Campaign, stating as he declared his vote: "I believe in the expansion and recognition of rights, that is why my vote is in favor. In favor of settling the debt of democracy with women and people with gestational capacity, because we have a stake in a future where no one denies a right to anyone., ${ }^{305}$

The IVE Law meets the first two prerequisites of Stoddard's cultureshift test. The IVE Law decriminalized abortion and established that abortion access should not only be legal and safe but also cost-free. Moreover, the IVE Law had the effect of shifting the underlying rationale for abortion access from a question of privacy to one of health and human rights. Certainly that is evidence of the breadth of change it brought to Argentine society. The debates leading up to passage of the IVE Law also helped it meet the public awareness element. The Campaign's broad-based grassroots campaign and its interaction with other mass mobilizations in Argentine politics made it impossible for the general public to ignore the abortion issue.

${ }^{300}$ AlCARAZ, supra note 295.

${ }^{301}$ Politi \& Londoño, How Support Went Mainstream, supra note 249.

${ }^{302}$ Alcaraz, supra note 295; Marcia Dell'Oca, Ni Una Menos: Con menos concurrencia, la legalización del aborto se quedó con el protagonismo, La Política OnLine (June 3, 2019) (Arg.), https://www.lapoliticaonline.com.ar/nota/119639-ni-una-menos-con-menosconcurrencia-la-legalizacion-del-aborto-se-quedo-con-el-protagonismo/

[https://perma.cc/86M9-H4YV] (noting that purple is the color of the Ni Una Menos movement).

${ }^{303}$ Sutton \& Vacarezza, supra note 139 , at 742.

${ }^{301}$ Ferraro, supra note 210 (translated into English by the author).

${ }^{3005}$ Id. 


\section{Legitimacy of the Change}

As for the third element of culture shifting-that the change be accepted as legitimate or valid-the IVE Law automatically meets Stoddard's prerequisite because it was an act of legislative lawmaking. ${ }^{306}$ Stoddard has a preference for legislative lawmaking over judicial lawmaking, as did Justice Ginsburg, because of the greater potential that legislative enactments have for the "absorption into the society of new ideas and relationships." ${ }^{307}$ For Justice Ginsburg, the Court's handling of Roe undermined the development of the public discourse on abortion. If the question had not been decided from on high by the Supreme Court, she surmised, the machine of majoritarian politics would have ensured that the then-ongoing public debate on reproductive rights would develop, potentially leading to broader social consensus about the right to choose. ${ }^{308}$ She asserted that state laws liberalizing abortion access would have had greater legitimacy than a mandate from the high court. This section will address the advantages of legislation to foment cultural change but will also consider the danger that exclusive reliance on majoritarian politics poses for minoritized and marginalized communities, including women and others with gestational capacity.

Stoddard suggests that, as compared to judicial decisions, legislation carries "a presumption of democratic legitimacy" because of the politicking inherent in this lawmaking process. ${ }^{309}$ Legislators need to win elections, listen to their constituents, stake out their own positions, and negotiate with each other in order to pass legislation. This process, he argues, is more likely to lead to public acceptance and the "moral and cultural legitimacy [required] to sustain widespread adherence to any new code of conduct." ${ }^{\text {,10 }}$ His example of indoor smoking bans passed in the late 1980s and early 1990s both proves and disproves his point. In New York City, the ban produced a tangible cultural shift, even incentivizing some smokers to quit. ${ }^{311}$ Across the ocean, however, Paris had passed a similar anti-smoking ordinance in $1991,{ }^{312}$ but Parisians responded by flouting the new rule until it became a nullity. ${ }^{313}$ Paris's smoking ban was the result of majoritarian politics in the

\footnotetext{
${ }^{306}$ See Stoddard, supra note 235, at 985 (asserting that legislation carries "a presumption of democratic legitimacy" and explaining how the Civil Rights Act of 1964 met this element of the culture-shifting framework).

${ }^{307} I d$.

${ }^{308}$ See supra text accompanying note 11 .

${ }^{309}$ Id.

${ }^{310}$ Id. at 983.

${ }^{311}$ Id. at 982 .

${ }^{312}$ Elaine Sciolino, PARIS JOURNAL: No Longer Trés Chic, Smoking Loses Favor in France, N.Y. TIMES (Oct. 6, 2006), https://www.nytimes.com/2006/10/06/world/europe/smoking-no-longer-tres-chic-infrance.html [https://perma.cc/CCM4-HMPF].

${ }^{313}$ Stoddard, supra note 235 , at 982.
} 
municipal government, but it failed because those subject to the new rule regarded it as "culturally illegitimate."

The question about legitimacy is not simply assuming that legislative reforms will more likely lead to changes that people will accept but understanding that law and culture are mutually constitutive. For example, a 2019 study of medical professionals in Argentina observed a correlation between changing legal rules about abortion access and a decrease in stigma for abortion providers. ${ }^{315}$ In 2002, the Sexual Health and Responsible Procreation ("SHRP") Law was enacted. ${ }^{316}$ This law allowed medical staff to provide information to patients about abortion, although Article 85 still prevented them providing abortion services. ${ }^{317}$ The SHRP Law was followed in 2012 by the CSJN's decision in F., A.L. case. In combination with the 2015 Guideline, these three legal documents gave medical providers legal and policy support to provide abortion services. ${ }^{318}$ The uncertainty about what situations fell into the non-punishable abortion category disappeared and with that disappearing uncertainty, doctors and other medical staff began to come out as pro-choice. ${ }^{319}$ Even prior to the IVE Law, the rule change had provided a foundation of legitimacy upon which these medical professionals could stand firmly. ${ }^{320}$

The culture-shifting model accurately captures the notion that law and culture are mutually constitutive; nevertheless, it does not address the way in which law and legal systems a priori constitute the structures and frameworks in which social change is permitted to occur. Understood this way, a choice between legislation and judicial review is not a real choice at all. ${ }^{321}$ Or at least this dichotomy does not present the entire universe of options available to advocates for social change. The question ought to go beyond legislation versus litigation because legal institutions are inherently

${ }^{34} I d$. at 983 . The national government of France passed a stricter anti-smoking ban in 2007 and phased its implementation over two years. Geoffrey T. Fong, Lorraine Craig, Romain Guignard, Gera Nagelhout, Megan Tait, Pete Driezen, Ryan Kennedy, Christian Boudreau, Jean-Louis Wilquin, Antoine Deutsch \& François Beck, Evaluation the Effectiveness of France's Indoor Smoke-Free Law 1 Year and 5 Years after Implementation: Findings from the ITC France Survey, 8 PLOS One 1, 1 (June 21, 2013). These restrictions came only after a five-month study and after implementation, a longitudinal study showed that support for the law increased substantially. Id.; Sciolino, supra note 312.

${ }^{315}$ Fernández Vázquez \& Brown, supra note 26, at 67.

${ }^{316} I d$. at 71 .

${ }^{317}$ Id. at 69 .

${ }^{318} I d$. at 71 .

${ }^{319}$ Id.; Ruibal \& Fernandez Anderson, supra note 154, at 10-11; McReynolds-Pérez, supra note 153 , at 97 .

${ }^{320}$ Fernández Vázquez \& Brown, supra note 26, at 70-71.

${ }^{321}$ See Stephen Macedo, Against Majoritarianism: Democratic Values and Institutional Design, 90 B. U. L. REv. 1029, 1039, 1041 (2010) (noting that litigation strategies can drain political energies and other resources while acknowledging the opportunity costs of mass mobilizations). 
conservative and will always defend the status quo. Litigation and legislation both require the involvement and consent of the legal system, a set of institutions which inevitably dilute the power of radical social change. In this regard, Gerald Torres has observed: "By building in the capacity (or perhaps the obligation) for serious political disagreement to be channeled into preexisting ways of comprehending the essential nature of the political community, change can be moderated and truly disruptive transformation can be avoided., ${ }^{322}$

Social change advocates can and do generate legitimate and valid social change outside of legal institutions. Verónica Gago and Marta Malo speak to the way the green tide of feminism in Argentina "reconfigured political antagonism” ${ }^{323}$ not only by transgressing but by reimagining traditional political forms and arenas. The feminist movement in Argentina, including the Campaign for Legal, Safe, and Cost-Free Abortion, rejected the strictures of the existing legal system and demanded radical new dynamics and distributions of power. ${ }^{324}$ The Campaign exposed the fact that the legal system was not inviolate. Article 86's provision for non-punishable abortions, for example, was subject to both restrictive and liberal readings and the Campaign exploited that indeterminacy by occupying that void and creating new social meanings based on feminist principles. As discussed above, the Campaign did not choose only one path forward to decriminalize abortion. It maneuvered both within and apart from the established legal order to create new cultural norms and expectations of what society will accept as legitimate state power over a pregnant person's autonomous decision-making.

A final criticism of Stoddard's preference for legislative change remains. That is the question of whether the opportunity to exercise human rights should be left to majoritarian politics at all. One could argue that state laws restricting access to abortion are themselves examples of a culture shift that is broad in scope, has captured not only the public's attention but also garnered their support, and as evidenced by impact litigation initiated by anti-abortion activists, will be incessantly enforced. If this is true, can we be satisfied with a patchwork of state laws that regulate access to abortion, with some banning abortions entirely?

Judicial review has an important role to play in defending democracy and protecting human rights in the United States legal system. ${ }^{325}$ Judicial review is the essence of the U.S. Supreme Court, and this power helps to ensure that the dominant majority will not infringe on the rights and interests of minoritized groups, which in the case of abortion rights means the rights and interests of women and other persons with gestational

\footnotetext{
${ }^{322}$ Torres, supra note 242, at 137.

${ }^{322}$ Gago \& Malo, supra note 110, at 624.

${ }^{324} I d$.

${ }^{325}$ See Macedo, supra note 321 , at 1041.
} 
capacity. When the Supreme Court decided Brown v. Board of Education in 1954, for example, it ruled that school districts could not be left to individually decide whether and when to desegregate and that the constitutional guarantee to be free from racial subordination must be protected at a national level. ${ }^{326}$

Although she and Stoddard may have preferred a legislative resolution to abortion, Justice Ginsburg certainly never wanted to go back, defending Roe and the abortion right it created. When asked about her remarks in the Joyner Lecture during her Senate confirmation hearings, she explained: "Abortion prohibition by the State . . controls women and denies them full autonomy and full equality with men." ${ }^{327}$ In 2018, Justice Ginsburg unequivocally stated: "Roe v. Wade, I should be very clear-I think the result was absolutely right." ${ }^{328}$ And although the decision in Roe may have preempted the ongoing social debate in 1973, fifty years later, in 2021, the right to abortion has certainly become "so rooted in the traditions and conscience of our people as to be ranked as fundamental. ${ }^{\prime 29}$ In other words, regardless of how abortion became legal in the United States, privacy is not the only rationale for maintaining that right today.

Argentina's political arena is dominated by social movements. ${ }^{330}$ Social movements are not marginal to Argentine politics; rather, they "are creators of meaning and are active contestants in the dynamic relationship between law and social change." ${ }^{331}$ The tradition of grassroots organizing and mass mobilization is well established and has a direct impact on the formulation of public policy. According to Elizabeth Gómez Alcorta, the current Minister of Women, Gender, and Diversity: "The street, as we call it, has a powerful effect on the contest of rights." ${ }^{332}$ And politicians are keenly aware of and in touch with the potency of mass social movements, like the Campaign. Speaking about President Fernández's successful campaign for office, which centered on his feminist politics, professor of political science Maria Victoria Murillo says: "He saw there was a grass-roots movement he wanted to seize on. Argentine politicians are very attuned to street movements." ${ }^{333}$ This well-developed and activated base is another good sign for the staying power of legal abortion in Argentina.

\section{Continuous Enforcement}

\footnotetext{
${ }^{326}$ Brown v. Bd. of Educ., 347 U.S. 483 (1954).

${ }^{327}$ Senate Confirmation Hearing, supra note 9, at 208.

${ }^{3228}$ Rosen, supra note 11.

${ }^{329}$ See Roe, 410 U.S. at 174 (Rehnquist, J., dissenting) (quoting Snyder v. Mass., 291 U.S. 97 (1934)).

${ }^{380}$ GaGo, supra note 243, at 1.

${ }^{3}$ Ruibal \& Fernandez Anderson, supra note 154, at 4.

${ }^{322}$ Politi \& Londoño, How Support Went Mainstream, supra note 249.

${ }^{323}$ Id.
} 
The final element for lasting culture change is "overall and continuous enforcement" of the new rule by the government. ${ }^{334}$ For Stoddard, the notion of continuous enforcement encompasses "multiple systems," including civil and criminal penalties, and also the dissemination of information about the new rule "to promote public awareness and adherence." ${ }^{335}$ To this list of proactive measures for enforcement, I would add: vigorous defense of the new rule when faced with legal challenges. A culture shift in the general public does not, in and of itself, prevent litigation. However, if the ground has shifted significantly, perhaps it makes it less likely that litigation efforts will succeed. Courts are, after all, participants in society like the rest of us.

As discussed previously, the public debate on abortion decriminalization and the visible presence of the marea verde in the streets of Argentina have made ignorance of the abortion issue nearly impossible. Since the IVE Law passed, the national and provincial governments have continued to produce notices designed to spread public awareness and detailed information about the rights protected by the new law. For example, the official government website hosts a page of information about abortion rights and how to access these services. ${ }^{336}$ The National Ministry of Health has posted multiple times about the IVE Law on its social media accounts. ${ }^{337}$ On April 5, 2021, the Health Ministry's Twitter page announced: "The IVE Law is in force nationwide. If your health insurance or pharmacy is not complying with the process, you may file a complaint [here, providing a hyperlink].”338 The IVE Law explicitly provides for civil and criminal sanctions for failure to conform to the conscientious objector provisions and for unreasonably delaying abortion services. ${ }^{339}$ The Health

${ }^{334}$ Stoddard, supra note 235 , at 986 .

${ }^{335} \mathrm{Id}$.

${ }^{336}$ Ministerio de Salud de la Nación, Acceso a la interrupción del embarazo: IVE/ILE, ARGENTINA.GOB.AR (Arg.), https://www.argentina.gob.ar/salud/sexual/acceso-lainterrupcion-del-embarazo-ive-ile [https://perma.cc/57AW-AT6C].

${ }_{337}^{37}$ See, e.g., Ministerio de Salud de la Nación (@msalnacion), Instagram (Jan. 14, 2021), https://www.instagram.com/p/CKCzt4wg3qr/ [https://perma.cc/9XSZ-LKRX]; Ministerio de Salud de la Nación (@msalnacion), Instagram (Dec. 30, 2020), https://www.instagram.com/p/CJbeJ35gaba/ [https://perma.cc/2G5B-UR6E].

${ }^{338}$ Ministerio de Salud de la Nación (@msalnacion), TwitTer (Apr. 5, 2021, 9:23 AM), https://twitter.com/msalnacion/status/1379077217783844867 [https://perma.cc/D4PB2V4U] [hereinafter @msalnacion, TwITTER] (translated into English by the author) (announcing a national hotline to report failures of insurance companies to provide cost-free abortion services under the IVE Law).

${ }^{339}$ Law No. 27610, art. 10, Jan. 15, 2021, Ley del Acceso a la Interrupción Voluntaria del Embarazo [Interrupción Voluntaria del Embarazo] [IVE Law] [34.562] B.O. 10 (Arg.) (regarding conscientious objectors); id. at art. 15 (regarding Art. 85 bis penalties). In 2016, a Catholic psychologist convinced a twelve-year-old pregnant girl not to exercise her right to ILE. Juan Carlos Tizziani, La Corte ordenó nueva sentencia, PÁgIna 12 (Mar. 30, 2021) (Arg.), https:/www.pagina12.com.ar/332548-la-corte-ordeno-nueva- 
Ministry also coordinates an information hotline, for free to the public. ${ }^{310}$

The varied publication types are designed to reach a broad swath of society, including persons with intellectual disabilities, persons with limited Spanish such as foreigners living in Argentina, children who are beginning to read, the elderly who require assistance reading, and persons who may have difficulty understanding the written word. With these communities in mind, the National Ministry of Justice and Human Rights published an Easy-Reading Guide to the IVE Law. ${ }^{341}$ Reminiscent of the Everything You Want to Know about How to Perform an Abortion with Pills handbook published in 2010 by the group Lesbians and Feminists for the Decriminalization of Abortion, ${ }^{342}$ this official publication contains straightforward information that the general public needs to know about the IVE Law. The easy-reading guide has a purple cover with a cartoon drawing of a patient dressed in Campaign green and a doctor. Similar friendly images appear throughout the short guide, which explains in plain terms the pregnant person's rights and the obligations of the medical establishment. ${ }^{313}$ One of the rights provided by the IVE Law is the right to understand all the information that is presented. ${ }^{34}$ The easy-reading guide satisfies, in part, the government's obligation in that regard. ${ }^{3+5}$

In March 2021, the National Ministry of Health published the Protocol for the Comprehensive Care of Persons with the Right to Voluntary and Legal Interruption of Pregnancy ("2021 Protocol"). ${ }^{3+6}$ This document provides detailed and comprehensive guidance for health care institutions and individual providers nationwide. ${ }^{377}$ Part I of the 2021

sentencia?fbclid=IwAR1TsvSf6V6tWcoUl0T_mlHGVe0xjOFx92TZ1Zje05W8cd0KETZ DjbsYm2k [https://perma.cc/3LR6-8FYV]. The ethics board of the College of Psychologists imposed a professional sanction by suspending her license for six months. Id. Although the criminal court for Santa Fe Province vacated that sentence, the CSJN unanimously ordered that a new sentence be imposed. Id.

${ }^{3 * 0} @$ msalnacion, TwiTTER, supra note 338.

${ }^{34}$ Ley de Interrupción Voluntaria del Embarazo en lectura fácil, MiNiSTERIO DE JUSTICIA Y Derechos Humanos [Ministry of Justice \& Human Rights] (Apr. 2021) (Arg.), https://www.argentina.gob.ar/sites/default/files/2021/06/ive-lectura_facil.pdf

[https://perma.cc/W6GZ-E4MM] [hereinafter Easy-Reading Guide] (listing a list of the intended audience).

See Sutton \& Vacarezza, supra note 139, at 775.

${ }^{34}$ See Easy-Reading Guide, supra note 341, at 5, 7.

${ }^{3 n}$ IVE Law, art. 5(e) (Arg.).

${ }^{345}$ Easy-Reading Guide, supra note 341 , at 5 .

${ }^{316} 2021$ Protocol, supra note 215 . It is also specifically directed to non-medical administrative and security staff working on site. Id. at 14 .

${ }^{347}$ The national guide was preceded by a similar protocol from the Province of Buenos Aires on January 18, 2021. See Guia de implementación de la interrupción voluntaria del embarazo en la provincia de Buenos Aires en el marco de la Ley Nacional No 27.610, Ministerio de SAlud de la Provincia de Buenos Aires (Arg.), https://ministeriodelasmujeres.gba.gob.ar/drive/archivos/guiaimplementacionive.pdf 
Protocol begins with a meticulous review of the IVE and ILE legal framework. ${ }^{318}$ Part II provides specific medical policies and procedures, including guidelines for assisting the pregnant patient in deciding the most appropriate abortion method under the particular circumstances. ${ }^{349}$ The entire Protocol places the patient at the center of the decision-making process, with health care workers playing subordinate roles. The sentence summarizing the section titled "The Right to Abortion" illustrates this principle well: "The decision of the pregnant person is not to be doubted and should not be undermined by the personal or religious judgments of health care professionals." ${ }_{350}$

The 2021 Protocol is effectively an update to the 2007 Technical Guide and its successive editions ${ }^{351}$ and is itself evidence of a long-term strategy of Campaign activism within the governmental bureaucracy. It also contains an outline of legal arguments, based in domestic and international law, that affirmatively declares the legality of the IVE Law.

Litigation is a political strategy that has become associated with the religious right, the main opponents to abortion rights in Argentina, as the primary tactic for resisting progressive legislative reforms. ${ }^{3.52}$ In Argentina, the women's, feminist, and queer movement(s) helped gain rights to divorce, marriage equality, and legal abortion by displacing dominant religious discourses with science, bioethics, and the law. ${ }^{353}$ Anti-abortion groups have reacted to these progressive legal reforms by coalescing around notions of heterosexual monogamy and a woman's childbearing role. ${ }^{354}$ Anti-abortion groups that have lost ground in the public debate have increasingly turned to the courts as an alternative means of defending conservative religious values. ${ }^{355}$ As Soledad Deza, the lawyer who

[https://perma.cc/8WZ9-VT39]; see also Gobierno de la Provincia de Buenos Aires Res. RESOC-2021-1-GDEBA-MMPGYDSGP (2021) (Arg.), http://www.ms.gba.gov.ar/sitios/media/files/2021/02/RSC-2021-01477806-GDEBAMMPGYDSGP.pdf [https://perma.cc/VG98-43M6].

2021 Protocol, supra note 215, at 12-44.

See id. at 55-57 (providing guidelines for running medical tests to determine the factors that impact decision-making, such as the physical health of the pregnant person and the gestational age of the fetus).

${ }^{250} I d$. at 15.

${ }^{351}$ See id. at 4-5 (listing the antecedents to the 2021 Protocol, beginning with the 2007 Technical Guide). Valeria Isla, the current Director of the Department of Sexual and Reproductive Health of the National Ministry of Health, was the coordinator of both the 2007 and 2021 versions of these guides. Id.

${ }^{352}$ María Eugenia Monte \& Juan Marco Vaggione, Cortes irrumpidas. La judicialización conservadora del aborto en Argentina, 9 Revista Rupturas 107, 109, 112 (2019) (Costa Rica) (tracking the rise of anti-abortion and anti-reproductive rights organizations in Argentina to the successes of progressive political organizing around the secularization of majoritarian lawmaking).

${ }^{253}$ Id. at 112.

${ }^{354}$ See id. at 112, 115.

${ }^{355}$ Id. at 109. 
represented the teenager prosecuted for a miscarriage in Tucumán, observed: "The art of litigating rights belongs to the religious conservatives and to the political neoconservatives. Faced with the loss of the status quo in the democratic future, they resort to the judiciary." "356 Importantly, the politics of those groups are firmly grounded in religious doctrine, and in particular, in Catholicism. ${ }^{3.7}$

Even prior to the IVE Law, anti-reproductive rights groups used judicial processes (including lawsuits and participation as amici and intervenors) to impede access to contraception and to criminalize the lawful exercise of non-punishable abortions. ${ }^{358}$ The principal argument relied upon by anti-abortion groups is that the IVE Law is unconstitutional. This is, by now, a hackneyed argument that dates back to at least the $F$., A.L. case.

In F., A.L., claiming to represent unborn children, the Chubut Public Prosecutor argued that the Argentine state was obligated to protect life from the moment of conception, per Article 75, paragraph 23 of the Constitution. ${ }^{359}$ The CSJN explained that the textual reference to "children,

${ }_{356} \mathrm{E} \mathrm{El}$ arte de judicializar derechos le pertenece a los conservadurismos religiosos y neoconservadurismos políticos. Frente a la pérdida del status quo en el devenir democrático se repliegan al Poder Judicial." Santiago Brunetto, Aborto legal: los argumentos para rebatir los posibles planteos de inconstitucionalidad, PÁGINA 12 (Jan. 4, 2021, 12:16 AM) (Arg.), https://www.pagina12.com.ar/315157-aborto-legal-los-argumentos-para-rebatir-los-posiblesplante [https://perma.cc/TTA6-AK3U].

${ }^{337}$ Monte \& Vaggione, supra note 352, at 110-11. Pope Francis is Argentinian and ministered in Buenos Aires as Jesuit Cardinal Jorge Bergoglio before elected as leader of the Roman Catholic Church in 2013. Id. Religion may be a significant reason that Argentina is now only one of three other Latin American countries that allows early-term abortions with no restrictions. Politi \& Londoño, Argentina Legalizes Abortion, supra note 130. The other three are: Cuba (1965), Guyana (1995), and Uruguay (2012). Id. Although there is great religious diversity within Latin America, Christian churches still dominate the social, cultural, and legal landscape. Brendan Jamal Thornton, Changing Landscapes of Faith: Latin American Religions in the Twenty-First Century, 53 Latin Am. Rsch. Rev. 857 (2018); Kane, supra note 232, at 363-64.

${ }^{358}$ Monte \& Vaggione, supra note 352, at 115-18. Porto de Belén has used a variety of legal mechanisms, including filing injunctions and writ of collective constitutional appeal ("amparo colectivo"), as obstruction tactics against progressive laws such as access to the "morningafter" pill and Law 25,657, which created the National Program of Sexual Health and Responsible Procreation. Id. at 120; Virginia Digón, Aborto: Portal de Belén presentó el primer amparo en Córdoba contra la ley IVE, La VOZ (Feb. 4, 2021) (Arg.), https:/www.lavoz.com.ar/ciudadanos/aborto-portal-de-belen-presento-primer-amparo-encordoba-contra-ley-ive [https://perma.cc/24CK-DN2W].

${ }^{359}$ Corte Suprema de Justicia de la Nación [CSJN] [National Supreme Court of Justice], 13/3/2012, “F., A. L. s/ medida autosatisfactiva,” Fallos (2012-335-197), II 3 (Arg.). In full, Article 75, paragraph 23 provides that the Congress shall have the power:

To legislate and promote proactive measures that guarantee true equality of opportunity and treatment, and the full enjoyment and exercise of the rights recognized by this Constitution and by current international treaties on human rights, in particular with respect to 
from gestation through the end of elementary schooling" did not involve an obligation to protect fetal life, but rather a means to provide social support services to the pregnant mother. ${ }^{360}$ In its full context, Paragraph 23 establishes the duty of the government "[t]o enact a special and integral social security system that protects needy children, from gestation through the end of elementary schooling, and that protects the mother during pregnancy and nursing." ${ }^{361}$ Moreover, the CSJN cited the vibrant debate about the right to life that took place during the constitutional convention of 1994. ${ }^{362}$ During that vigorous debate, no mention was made about eliminating the extant provisions of Article 86's non-punishable abortions. ${ }^{363}$

To support its anti-abortion position, Chubut also cited international treaties to which Argentina is a party. ${ }^{364}$ The CSJN rejected these arguments, explaining that none of those international agreements established the unconditional right to life for a fetus. ${ }^{365}$ To the contrary, judicial bodies endowed with authority to resolve disputes based on the rights articulated in these documents, have come to the same conclusion. For example, Article 4 of the American Convention on Human Rights establishes that the right to life "shall be protected by law, and, in general, from the moment of conception." " ${ }^{366}$ In the Baby Boy case, the Inter-American Court for Human Rights held that the qualifying language meant that fetal right to life was not absolute but instead gains in importance incrementally over time. ${ }^{367}$ The "in general" language of Article 4 was included specifically for the purpose of

children, women, the elderly and people with disabilities.

To enact a special and integral social security system that protects needy children, from gestation through the end of elementary schooling, and that protects the mother during pregnancy and nursing.

Art. 75, para. 23, Constitución Nacional [CONST. NaC.] (Arg.), translated in Argentina's Constitution of 1853, Reinstated in 1983, with Amendments through 1994, Constitute Project 19 (Aug. 21, 2021, 4:17 PM), https://www.constituteproject.org/constitution/Argentina_1994.pdf?lang=en [https://perma.cc/J94Z-J2FJ].

${ }^{360}$ CSJN, 13/3/2012, “F., A. L. s/medida autosatisfactica," Fallos (2012-335-197), II 9.

${ }^{361}$ Art. 75, para. 23, CONSTITUCiÓN NACIONAL [CONST. NAC.] (Arg).

${ }^{362}$ CSJN, 13/3/2012, “F., A. L. s/medida autosatisfactica," Fallos (2012-335-197), II 9.

${ }^{363} \mathrm{Id}$.

${ }^{364}$ Id. at II 3 (citing American Declaration of the Rights and Duties of Man, art. 1; American Convention on Human Rights, art. 3-4; Universal Declaration of Human Rights, art. 3, 6; International Convention on Civil and Political Rights, art. 6; Convention on Rights of the Child, Preamble, art. 1, 6).

${ }^{365}$ See, e.g., id. at II 10 (discussing the American Convention on Human Rights).

${ }^{366}$ Organization of American States, American Convention on Human Rights, art. 4, II 1, Nov. 22, 1969, https://www.oas.org/dil/treaties_b32_american_convention_on_human_rights.pdf [https://perma.cc/U9Z8-BNNX] (emphasis added).

${ }^{367}$ Baby Boy v. United States, Case 2141, Inter-Am. Comm'n H.R., Report No. 23/81, OEA/Ser. L/V/II.54, doc. 9, rev. 1, II 15 (1981). 
respecting and permitting abortion in state parties where abortion is legal. ${ }^{368}$

Likely anticipating similar arguments as to its validity, the IVE Law itself affirmatively cites Article 75, Paragraph 22 of the Constitution, which provides that international treaties to which Argentina is a state party stand on equal footing with the Constitution. ${ }^{369}$ As human rights lawyers Soledad Deza and Luciana Sánchez have noted, this also means abiding by the fourteen or more recommendations from international organizations that have urged increased access to abortion services as a matter of health and human rights. ${ }^{370}$ In summary, neither the constitutional nor the international law arguments that anti-abortion activists have raised against the IVE Law are likely to prevail as long as national and provincial courts follow the reasoning of the CJSN in the $F$., A.L. case. ${ }^{371}$

Nevertheless, several challenges to the IVE Law have already been filed, in both national and provincial courts throughout the country. ${ }^{372}$ Only national courts have jurisdiction over constitutional issues, but Argentina's judicial system empowers both national and provincial courts to hear cases pertaining to federal law. ${ }^{373}$ The IVE Law amends key provisions of the Penal Code and implicates provisions of the Civil and Commercial Code

${ }^{368} I d$. at $\mathbb{1} 19$.

${ }^{369}$ Law No. 27610, art. 3, Jan. 15, 2021, Ley del Acceso a la Interrupción Voluntaria del Embarazo [Interrupción Voluntaria del Embarazo] [IVE Law] [34.562] B.O. 3 (Arg.).

${ }^{370}$ Brunetto, supra note 356. See, e.g., Human Rights Committee, Consideration of reports submitted by States parties under article 40 of the Covenant, Concluding observations by the Human Rights Committee: Argentina,” CCPR/C/ARG/CO/4 (Mar. 31, 2010), para. 3; Committee on the Rights of the Child, "Concluding observations on the combined fifth and sixth periodic reports of Argentina," CRC/C/ARG/CO/5-6 (Oct. 1, 2018), para. 32 ("the Committee recommends that the State party ... Ensure access to safe abortion and postabortion care services for adolescent girls, ensuring their views are always heard and given due considerations as part of the decision-making process").

${ }^{371}$ But see Legarre, Precedent, supra note 112, at 789 (describing how Argentine lower courts, both provincial and national, may permissibly ignore precedent from the CSJN).

${ }^{372}$ See, e.g., Politi, supra note 226 (reporting that a judge in Chaco had issued a preliminary injunction blocking the IVE Law from taking effect in that province); Chaco ya tiene aborto legal: revocaron un fallo contra la ley de IVE, Chaco Día POR Día (Mar. 19, 2021) (Arg.), https://www.chacodiapordia.com/2021/03/19/chaco-ya-tiene-aborto-legal-revocaron-unfallo-contra-la-ley-de-ive/ [https://perma.cc/6GE5-Y2DT] (reporting that the injunction in Chaco had been lifted, with Scribd link to the case); News, Red De Acceso Al AborTo SEguro (Jan. 2021) (Arg.), http://www.redaas.org.ar/noticias-actualidad\#2021-01 [https://perma.cc/Y7CL-KQJB] (containing more updates).

${ }^{373}$ Art. 75, para. 12, CONSTITUCión Nacional [CONST. NAC.] (Arg.). Argentine "national law" encompasses many more areas of law than in the United States. The Constitution empowers the Congress to create legislation in the areas of civil, commercial, and criminal matters. Provincial courts are authorized to resolve disputes arising under these national laws in their respective territories, but the CSJN and its inferior courts retain jurisdiction over all constitutional matters. Id. at art. 116. See also Santiago Legarre, Common Law, Civil Law, and the Challenge from Federalism, 3 J. OF CIV. L. STUD. 167, 173-76 (2010) (describing the overlapping jurisdiction of the national and provincial courts as a product of Argentine history). 
and is therefore federal law. ${ }^{374}$ Most of the challenges have taken the form of demands for injunctive relief, through a writ of amparo (emergency juridical relief for fundamental rights violations). ${ }^{375}$ Some challenges have been dismissed outright, but others have been granted by judges sympathetic to the anti-abortion arguments. ${ }^{376}$ Thus far, however, in each of the cases in which some form of injunctive relief has been granted, they have all been overruled or suspended pending further hearing. ${ }^{377}$

\section{CONCLUSION}

It is impossible to prove whether Justice Ginsburg was right about Roe because her arguments were based on a counterfactual. We cannot know whether states would have eventually liberalized abortion access or whether the liberalizing trend among the states in 1973 would have been met with the same vigorous protests and legal challenges mounted by organized antiabortion groups. What we do know is that the right of pregnant people to choose abortion in the United States came through the vehicle of a judicial decision of the Supreme Court, in the same way that the Court struck down de jure racial discrimination laws and determined that the Constitution protected marriage equality as a fundamental right. And, fifty years on, that right is in jeopardy.

${ }^{37}$ See, e.g., Law No. 27610, art. 14 (Arg.) (amending Código Penal [Cód. Pen.] [Criminal Code] art. 85 (Arg.)); Id. at art. 8 (referencing Código Procesal Civil y Comercial de la Nación [Cód. Proc. Civ. y Com.] [Civil and Commercial Procedure Code] art. 26 (Arg.)).

${ }^{375}$ Gloria Orrego Hoyos, Update: The Amparo Context in Latin American Jurisdiction: An Approach to Empowering Action, GlobaLex, https://www.nyulawglobal.org/globalex/Amparo1.html\#thewritof [https://perma.cc/U36H$9 \mathrm{MXF}]$. The writ of amparo is a procedural tool that any person who claims a constitutional or human rights violation may use to guarantee those rights. Art. 43, Constitución NaCional [CONST. Nac.] (Arg.). Law 16,986 prohibits the use of the amparo to challenge the constitutionality of congressional acts or administrative regulations. Mairal, supra note 113 , at 12.

${ }^{376}$ Leszinsky, supra note 217. Of note is a case in Chaco where Judge Marta Beatriz Aucar de Trotti issued a preliminary injunction in January 2021, suspending implementation of the national IVE Law in the province, pending litigation. Una jueza de Chaco hizo lugar a cautelar que suspende la vigencia de la Ley IVE en la provincia, TÉLAM (Jan. 28, 2021) (Arg.), https://www.telam.com.ar/notas/202101/542915-chaco-jueza-cautelar-suspendevigencia-ley-ive.html [https://perma.cc/P8WW-ZEZ8]. By March, an appeals court had withdrawn the injunction. CHACO DíA POR DíA, supra note 372.

${ }^{377}$ See, e.g., Ramiro Vélez, Suspendieron la cautelar que frenaba la ley de IVE, PaLABras DEL DERECHO (June 17, 2021) (Arg.), https://palabrasdelderecho.com.ar/articulo/2754/Suspendieron-la-cautelar-que-frenaba-laley-de-IVE [https://perma.cc/X29M-ZPVN] (describing and linking to a decision in Mar del Plata); Soledad Vallejos, Aborto legal: el fiscal de Mar del Plata dictaminó que se debe rechazar la cautelar para suspender la ley, PÁGINA /12 (July 1, 2021) (Arg.), https://www.pagina12.com.ar/351647-aborto-legal-el-fiscal-de-mar-del-plata-dictamino-quese-deb [https://perma.cc/AF8Z-AG23] (same). 
Although we can never know for sure whether Justice Ginsburg was right, the story of how the IVE Law came to be in Argentina gives us something very close to the legislative path to achieving social change that she would have preferred to Roe. Building on decades of grassroots organizing and feminist praxis, the Campaign successfully delivered a national law that provides legal, safe, and cost-free abortion as a matter of health and human rights. It only took seventy-four years from the day that women gained the right to vote in Argentina. At any rate, early signs indicate that the IVE Law will be better able to withstand legal challenges. This Article has argued that, if true, it will be in large part because cultural norms and expectations around abortion have shifted substantially during the past several decades. The IVE Law will certainly be a model for other Latin American countries working towards reproductive justice. If the U.S. Supreme Court overrules Roe in the coming months, the Campaign's success story may also become a playbook for the United States. 


\section{APPENDIX I}

Access to Voluntary Interruption of Pregnancy

Law 27,610

\section{Provisions.}

The Senate and the House of Representatives of the Argentine nation meeting in Congress sanction with force of law:

Article 1. Purpose. This act regulates access to voluntary interruption of pregnancy and access to post-abortion medical care, in compliance with the commitments assumed by the State with regards to public health and the human rights of women and people with other gender identities with gestational capacity, with the goal of reducing and preventing maternal morbidity and mortality.

Article 2. Rights. Women and other persons with gestational capacity have the right to:

a) Choose to interrupt a pregnancy in conformance with this law;

b) Demand and receive attention for the interruption of a pregnancy in the health care system, in conformance with this law;

c) Demand and receive post-abortion care in the health care system, without prejudice with regard to the decision to terminate the pregnancy, even if the abortion is contrary to the provisions of this law;

d) Prevent unintended pregnancies through access to information, comprehensive sex education, and to effective contraceptive methods.

Article 3. Constitutional Framework. This Act is supported by Art. 75(22) of the National Constitution, and the human rights treaties ratified by the Argentine Republic-in particular the Universal Declaration on Human Rights, the American Convention of Human Rights, the Convention on the Elimination of All Forms of Discrimination Against Women and its protocols, the International Convention on Economic Social and Cultural Rights, International Convention on Civil and Political Rights, the Belém do Pará Convention, the Convention on Rights for Persons with Disabilities, the Convention on Rights of the Child, and the Convention Against Torture-by virtue of the protections that these instruments grant for sexual and reproductive rights, to dignity, to life, to autonomy, to health, to education, to integrity, to bodily diversity, to gender 
identity, ethnic-cultural diversity, privacy, freedom of beliefs and thoughts, information, to enjoy the benefits of scientific advances, to true equality of opportunities, to anti-discrimination, and a life free of violence.

Article 4. Voluntary interruption of pregnancy. Women and other persons with gestational capacity have the right to decide and access abortion services until the 14th week of pregnancy.

Outside of the 14-week timeline, the gestating person has the sole right to decide and to access abortion under the following circumstances:

1. If the pregnancy was the result of rape, with the request for an abortion and a certified statement of the rape before an agent of the Health Ministry.

In cases of children under the age of 13 , the certified statement is not necessary.

2. If the pregnant person's life or health would be endangered.

Article 5. Rights related to health care services. All gestating persons have the right to obtain an interruption of pregnancy within the health care system or with its assistance, within a maximum of ten (10) calendar days from the date of request and under the conditions established in this law and in Laws 26,485 and 26,529.

Health care personnel must guarantee the following minimum conditions and rights with respect to abortion and post-abortion care:

1. Dignified treatment. Health care personnel must observe dignified treatment, respect the personal beliefs and moral values of the patient, in order to eradicate practices that perpetuate the exercise of violence against women and other persons with gestational capacity;

2. Privacy. Any medical-assistance activity aimed at obtaining and transmitting information and documentation from the patient's clinic must guarantee the creation and preservation of an environment of trust between the health care staff and the person requesting care, and observe strict respect for their privacy, human dignity, and autonomy, as well as the due protection of confidentiality; information 
will only be shared with the patient's family or companion with the patient's express authorization, in accordance with Article 8 of the present law.

Likewise, the patient must be protected from illegitimate interference by third parties.

In cases of rape of children or adolescents, both the obligation to communicate the violation of rights provided for in Article 30 of Law 26,061 and the duty to file a criminal complaint established in Article 24(e), of Law 26,485 within the framework of the provisions of Article 72 of the Penal Code, must be complied with while respecting the right to privacy and confidentiality, the progressive capacity and superior interest in accordance with the Convention on the Rights of the Child, Law 26,061 and Article 26 of the Civil and Commercial Code, and no one must obstruct or delay access to the rights established in this law;

3. Confidentiality. Health care personnel must create the conditions for the protection of confidentiality and medical privacy during the entire health care process and afterwards. Health care personnel must inform the patient during the appointment that confidentiality is guaranteed and is covered by medical privacy.

Any person who participates in the preparation or handling of medical documentation or who has access to its content must respect the patient's right to confidentiality, except in cases where the patient has provided express written authorization;

4. Autonomy. Health care personnel must respect patient decisions regarding their reproductive rights, treatment alternatives, and their future sexual and reproductive health. The patient's decisions must not be subjected to prejudices on the part of the health care staff, and their free and autonomous will must be respected.

5. Access to information. Health care workers must actively and respectfully listen to patients so that the patients may freely express their needs and preferences. The patient has the right to receive information about their health; the right to information includes the right not to receive inappropriate information in relation to the information requested. 
Information regarding the different methods for interrupting a pregnancy should be provided, including the scope and consequences of the practice. Said information must be up-to-date, understandable, truthful, and distributed in accessible language and formats.

Health workers and public officials are obliged to supply information regarding the rights protected by this law in a dynamic manner that runs throughout the health care process, even if the patient does not request it.

6. Quality. Health workers must respect and guarantee abortion services according to the scope and definition of the World Health Organization. Health care will be provided according to the standards of quality, accessibility, technical competence, with a range of available options, and up-to-date scientific information.

Article 6. Information and abortion services and sexual and reproductive health. Once a request for an interruption of pregnancy in conformity with Article 4 has been made, the health care service will make available to the pregnant persons who require it-within the framework of the National Program for Sexual Health and Responsible Procreation, Law 25,673, the following:

4. Information about the procedure to be performed and the necessary after-care, per the criteria of Article 5;

5. Comprehensive health care throughout the entire process;

6. Assistance with health care and adequate, up-to-date and science-based information, accessible to the needs of each person, as well as the provision of contraceptive methods provided for in the Compulsory Medical Program (PMO, for its initials in Spanish) and in Law 25,673, or the regulations that may replace that law in the future.

These requirements are not prerequisites for the provision of services to the patient. 
Article 7. Informed consent. Prior to carrying out the voluntary interruption of pregnancy, the patient must acknowledge their informed consent in writing, in accordance with the provisions of Law 26,529 and Article 59 of the Civil and Commercial Code. No one can be substituted in the personal exercise of this right.

Article 8. Minors. Within the framework established by the Convention on Rights of the Child, Law 26,0601, Article 7 of Annex I of Decree 415/06, Article 26 of the Civil and Commercial Code, and Resolution 65/15 of the National Ministry of Health, the request for a voluntary interruption of pregnancy must be carried out as follows:

a) Persons over sixteen (16) years of age have full capacity on their own to provide their consent to exercise the rights granted by this law;

b) In the case of person under sixteen (16) years of age, informed consent will be required per the terms of Article 7 and in accordance with the provisions of Article 26 of the Civil and Commercial Code, Resolution 65/15 of the National Ministry of Health, and in accordance with the Convention on Rights of the Child, Law 26,061, Article 7 of Annex I of Decree 415/06, and Regulatory Decree 1,282/03 of Law 25,673.

Article 9. Persons with restricted capacities. If a person has restricted capacity by virtue of a judicial disposition and the restriction is not related to the exercise of the rights granted by this law, that person may provide their informed consent without any impediment or need for prior authorization, and if desired, with the assistance of the support system provided for by Article 43 of the Civil and Commercial Code.

Persons who act as a support system do not represent nor are substitutes for the person with restricted capacity in the exercise of that person's rights, and therefore, the design of the support system must incorporate adequate safeguards so that there are no abuses and so that decisions are made by the rights-holder themselves.

If the judicial disposition of restricted capacity prevents the individual from providing consent for the exercise of the rights provided for in this law, or if the person has been declared legally incapacitated, that person must give consent with the assistance of their legal representative, or in the absence of that legal representative, then under the terms of Article 59 of the Civil and Commercial Code. 
Article 10. Conscientious objectors. Medical professionals who would be directly involved in the voluntary interruption of pregnancy have the right to exercise their conscientious objection. To exercise this right, the conscientious objector should:

a) Consistently maintain this position in all areas (public, private, or social security health care) where they exercise their profession;

b) In good faith, refer the patient so that they can be cared for by another medical professional in a timely manner and without delay;

c) Comply with the rest of their professional duties and legal obligations.

Health care workers may not refuse to terminate the pregnancy in cases where the pregnant person's health is in danger and requires immediate and urgent attention.

Conscientious objection is not grounds upon which to refuse to provide post-abortion care.

Failure to comply with the obligations established in this Article will give rise to disciplinary, administrative, criminal, and/or civil sanctions, as appropriate.

Article 11. Conscientious objectors; obligations of health care facilities. Health care facilities which do not have enough human resources to provide abortion services must foresee this need and make advance arrangements with another competent and comparable health care facility to make referrals. In all cases, the provision of abortion services must be in conformance with the provisions of this law. The procedures and costs associated with patient referral and transfer will be the responsibility of the facility performing the referral. All referrals contemplated in this Article must be billed in favor of the facility actually performing the service.

Article 12. Coverage and quality of benefits. The public health sector, the social insurance programs operating under Law 23,660 and Law 23,661, the National Institute for Social Services for Retirees and Pensioners created by Law 19,032, the entities and agents operating under the prepaid medicine regulatory framework of Law 26,682, the entities that provide care under Regulatory Decree 1,993/11, social insurances of the armed and security forces, the social insurances of the Legislative and Judicial Power, 
those included in university social insurance coverage under Law 24,741, and all agents and organizations that provide medical-assistance services to affiliated or beneficiary persons, regardless of legal status, must incorporate the comprehensive and cost-free coverage of the voluntary interruption of pregnancy contemplated in this law, under the standards recommended by the World Health Organization. These benefits are fully covered by the National Health Care Quality Assurance Program and PMO, along with diagnostic benefits, medications, and supportive therapies.

Article 13. Comprehensive sexual education and reproductive health. The national government, the provinces, the Autonomous City of Buenos Aires, and municipalities have the responsibility for implementing Law 26,150, the Comprehensive Sexual Health Education Act, which established proactive policies for the promotion and enhancement of the sexual and reproductive health of the entire population.

These policies must be framed within the objectives and scope established in Laws 23,798; 25,673; 26,061; 26,075; 26,130; 26,150; 26,206; 26,$485 ; 26,743$; and 27,499, in addition to the laws previously cited. The responsible government parties must also train teachers, professionals, and health care workers, as well as public officials, on gender perspectives and sexual diversity in order to equip these individuals to provide care, attention, and monitoring suitable for those requesting a voluntary interruption of pregnancy under this law.

Article 14. Amendments to the Penal Code. The language of Article 85 of the Penal Code should be substituted with the following:

Article 85. He or she who causes an abortion will be punished:

1. With imprisonment of three (3) to ten (10) years, if the criminal actor operated without the consent of the pregnant person. If the pregnant person dies as a result, this penalty may be aggravated to fifteen (15) years.

2. With imprisonment of three (3) months to one (1) year, if the criminal actor operated with the consent of the pregnant person after the fourteenth (14th) week of gestation, and provided that the provisions of Article 86 do not apply.

Article 15. Adding Article 85 bis to the Penal Code. The following language shall be added to the Penal Code:

Article 85 bis. Anyone who unjustifiably delays, obstructs, or refuses to perform a legal abortion in contravention of current regulations will be 
subject to imprisonment of three (3) months to one (1) year, with a special disqualification of double the sentence imposed for public officials, those with authority over a health care facility, and health care workers.

Article 16. Substitution of Article 86 of the Penal Code. The language of Article 86 of the Penal Code should be substituted with the following:

Article 86. An abortion up to the fourteenth (14th) week of gestation, obtained with the consent of the pregnant person, is not a crime.

Outside of the period established in the previous paragraph, abortions performed with the consent of the pregnant person are not punishable:

1. If the pregnancy was the result of a rape. Under these circumstances, the practice will be guaranteed when the pregnant person makes a sworn statement before the health care professional or worker.

The sworn statement will not be required in cases involving children under thirteen (13) years of age.

2. If the life or health of the pregnant person is at risk.

Article 17. Substitution of Article 87 of the Penal Code. The language of Article 87 of the Penal Code should be substituted with the following:

Article 87. One who uses violence to cause the abortion of a person known or reasonably known to be pregnant, even without having the intention of causing the abortion, will be subject to imprisonment of six (6) months to three (3) years.

Article 18. Substitution of Article 88 of the Penal Code. The language of Article 88 of the Penal Code should be substituted with the following:

Article 88. A pregnant person who causes or allows another to cause an abortion after the fourteenth (14th) week of gestation and if the provisions of Article 86 do not apply, will be subject to imprisonment of three (3) months to one (1) year. The penalty may be waived if the circumstances excuse the conduct.

The pregnant person's attempted abortion is not punishable.

Article 19. Training. Health personnel must be trained in the contents of this law and its accompanying administrative regulations. To this end, the 
National Ministry of Health and the provincial ministries and the ministry of the Autonomous City of Buenos Aires will implement training programs.

Article 20. Enforcement authority. Enforcement of this law will be established by the under the National Executive Power.

Article 21. Public order. The provisions of this law are of public order and of mandatory application in the entire territory of the Argentine Republic.

Article 22. Communication to the National Executive Power.

PROMULGATED IN THE SESSION ROOM OF THE ARGENTINE CONGRESS, IN BUENOS AIRES, ON THE THIRTIETH DAY OF THE MONTH OF DECEMBER OF THE YEAR TWO THOUSAND TWENTY.

REGISTERED UNDER NUMBER 27,610.

CLAUDIA LEDESMA ABDALA DE ZAMORA - SERGIO MASSA - Marcelo Jorge Fuentes - Eduardo Cergnul

Date of publication: January 15, 2021 


\section{APPENDIX II}

National Law on Comprehensive Health Care During Pregnancy and Early Childhood Law 27,611

Provisions.

The Senate and the House of Representatives of the Argentine nation meeting in Congress sanction with force of law:

\section{NATIONAL LAW COMPREHENSIVE HEALTH CARE DURING PREGNANCY AND EARLY CHILDHOOD}

\section{CHAPTER I}

General provisions.

Article 1. Purpose. The purpose of this law is to strengthen the comprehensive care of the health and life of women and other pregnant people and of children in early childhood, in compliance with the commitments assumed by the State in matters of public health and the human rights of women and people with other gender identities with gestational capacity, and of their children, in order to reduce mortality, poor nutrition and malnutrition, to protect and stimulate early attachments, the physical and emotional development and overall health, and to prevent violence.

Article 2. Constitutional framework. The provisions of this law are supported by Article 75, paragraphs 19, 22, and 23 of the National Constitution, and in human rights treaties to which Argentina is a party-in particular, the Convention on the Rights of the Child (CRC), the Universal Declaration of Human Rights, the American Convention on Human Rights, the International Covenant on Economic, Social, and Cultural Rights (ICESCR), the International Covenant on Civil and Political Rights, the Convention on the Elimination of All Forms of Discrimination Against Women (CEDAW), the Convention on the Rights of Persons with Disability, the Inter-American Convention to Prevent, Punish and Eradicate Violence against Women (Convention of Belem do Pará), the InterAmerican Convention for the Elimination of all Forms of Discrimination Against Persons with Disabilities, and the Additional Protocol to the American Convention on Human Rights in the Area of Economic, Social and Cultural Rights (Protocol of San Salvador)-by virtue of the protection granted in them to the right to identity, integral health, healthy eating, to a 
dignified life free of violence, to social security, and to care in the first years of childhood.

Article 3. Guiding principles. The provisions and public policies established in this law are

complementary and are framed in those established in Laws 26,061 and 26,485 , and in the systems of protection therein defined.

In addition to the guiding principles established in the aforementioned laws, because pregnant people, infants, and toddlers are the beneficiaries of this law, this law establishes the following:

a. Comprehensive health care for women and other pregnant people, and for children up to three (3) years old;

b. Coordination by the relevant administrative agencies responsible for the creation of public policies aimed at children in early childhood up to three (3) years of age;

c. Simplification of the necessary procedures for access to social security rights;

d. Design and creation of public policies that provide assistance and adequate support so that families can assume their responsibilities for comprehensive health care;

e. Unrestricted respect for the best interests of the child and the principle of progressive autonomy;

f. Respect for the autonomy of women and other pregnant people;

g. Respect for a person's gender identity;

h. Access to information and training for the exercise of rights;

i. Specialized care in accordance with the intersection of rights and violations of those rights.

\section{CHAPTER II}

The right to social security.

Article 4. Assignment for Comprehensive Health Care. The following language should be added as subsection $(\mathrm{k})$ of Article 6 of Law 24,714: 


\section{(k) Assignment for Comprehensive Health Care.}

Article 5. Beneficiaries of the Comprehensive Health Care Allowance. The following language should be added as Article 14 octies of Law 24,714 and its amendments:

Article 14 octies: The Comprehensive Health Care Allowance will consist of the payment of a sum of money that will be paid one (1) time a year to the beneficiary defined in Article 1 of this law, for each child under three (3) years of age who is in her charge, provided that they have been entitled to the collection of the benefit established in subsection (i) of Article 6 within the calendar year, and provided that compliance with the vaccination and health control plan has been certified in accordance with the requirements that the National Social Security Administration (ANSES) will establish for this purpose.

Article 6. Amounts. The following language should be added as subsection (m) of Article 18 of Law 24,714 and its amendments:

(m) Assignment for Comprehensive Health Care: the highest amount set in subsections (a) or (b), as appropriate.

Article 7. Extension of the Pregnancy Allowance for Social Protection. The first paragraph of Article 14 quater of Law 24,714 and its amendments will be amended as follows:

Article 14 quater: The Pregnancy Allowance for Social Protection will consist of a monthly benefit monthly remuneration that will be paid to the pregnant person, from the beginning of their pregnancy until its termination or the birth of the child, provided that the benefit does not exceed nine (9) monthly payments and that it must be requested by the twelfth (12) week of gestation.

Article 8. Allowance for birth. Elimination of seniority. Article 12 of Law 24,714 and its

amendments, should be amended as follows:

Article 12. The childbirth allowance will consist of the payment of a sum of money that will be paid once the National Administration of Social Security (ANSES) has certified the birth.

Article 9. Assignment for adoption. Elimination of seniority. Article 13 of Law 24,714 and its amendments, should be amended as follows: 
Article 13. The adoption allowance will consist of the payment of a sum of money that will be paid once the National Administration of Social Security (ANSES) has certified the adoption.

Article 10. Extension of the birth allowance and adoption allowance. The following language should be added as Article 14 septies of Law 24,714 and its amendments:

Article 14 septies: The beneficiary identified in paragraph (c) of Article 1 of this law will have right to receive the allowances for birth and adoption established in subsections (f) and (g) of Article 6. To access these benefits, the putative beneficiary must prove the birth and/or the adoption before the National Social Security Administration (ANSES).

Article 11. Administrative regulations. The Executive Power, through its administrative agencies, must develop information exchange procedures to facilitate the verification of compliance with the requirements necessary for the collection of the benefits established in Law 24,714 and its amendments.

\section{CHAPTER III}

\section{Right to identity}

Article 12. System for Rapid Birth Notification. Digital certificate of vital events. Creation. A System for Rapid Birth Notification will be created within the National Registry of Persons (RENAPER, for its initials in Spanish), in order to guarantee the right to identity and the immediate registration and identification of newborns, in accordance with Articles 11, 12, and 13 of Law 26,061, on the Comprehensive Protection of Children and Adolescents.

The System will be implemented through the platform for the issuance of digital certificates of vital events, through which the intervening medical professionals must certify by electronic document and digital signature the person's vital data, in accordance with the provisions of Articles 30, 32, 34, 35, 62, 64 and 65 of Law 26,413, safeguarding the security and inviolability of data and in accordance with the regulations of the relevant agencies.

The National Registry of Persons, in coordination with the relevant executive agencies and with the Federal Council of the Registry of Civil Status and Capacity of Persons of the Argentine Republic, created by Article 93 of Law 26,413, will implement the Digital Certificate of Vital Data in 
accordance with the provisions of Articles 19, 24, and 25 of Law 17,671 and its amendments. The certificates issued in paper format will remain in force until the transition to digital is fully completed and is wholly implemented throughout the national territory.

The health care personnel, obstetrician, or agent in case of births outside of public or private medical care establishments who has attended the delivery and is authorized for this purpose, must report the birth to the corresponding Civil Status and Capacity of Persons Registry and to the National Registry of Persons within seven (7) calendar days of the birth and in the manner that said agency regulates.

Article 13. Tax exemption. Article 30 of Law 17,671, should be amended as follows:

Article 30. The following are exempt from paying the fees determined by this law to the Ministry of the Interior:

a. The public bodies that, in the exercise of their governmental functions, require documents, certificates, and testimonies, but these must bear the stamp of "Official Service";

b. People who do not have financial resources to pay the fee, their children under eighteen (18) years of age, or their children or other persons with restricted abilities of whom they stand as guardian. The National Registry of Persons is authorized to create any regulations that may be necessary for implementation, as well as for the necessary verification through the flow of information and interoperability with the databases of other national agencies.

Article 14. Immediate duty to inform. Article 27 of Law 26,413, should be amended as follows:

Article 27. The following will be registered in the birth registry:

a. All births that occur within the territory of the Nation. Said registration must be completed with the corresponding public official in the place of birth;

\section{b. Births whose registration is ordered by a competent judge;}

c. Births that occur in ships or aircraft of the Argentine flag before a public official in the first Argentine port or arrival airport; also births that occur in places under national jurisdiction; 
d. New registrations arranged as the result of an adoption;

e. Births in which paternity is established by voluntary recognition.

Once the birth has been registered in the local Registry of Civil Status and Capacity of Persons, it should also be delivered to the National Registry of Persons (RENAPER) within a maximum period of seven (7) calendar days.

Article 15. Late administrative registration. Article 29 of Law 26,413, shall be amended as follows:

Article 29. If the registration periods indicated in Article 28 have expired, registration may be made by administrative resolution, so long as the following precautions have been taken:

a. Negative birth certificate registration issued by the Civil Registry in the place of birth;

b. Certificate issued by an official doctor in which the age and date of birth are determined;

c. Report from the National Registry of Persons stating whether the person whose birth is to be registered is identified, registered, or enrolled, depending on which instrument is used to justify the birth; or, where appropriate, a pre-identification certificate, that contains the data and biometric information provided by the applicant, where there is no record of registration in the RENAPER; and

d. Statements under oath of two (2) witnesses regarding the place and date of birth, and the name and surname with which the person is publicly known.

If the applicant does not meet the requirements in the preceding paragraphs, or if their application has been denied at the local registry, the applicant should obtain the registration through the means of a judicial resolution. In these cases, the judge may use other evidence that she deems appropriate to verify the requirements according to each case.

In the case of registrations of minors, priority will be given to the Public Ministry of the jurisdiction in question.

\section{CHAPTER IV}


Right to comprehensive health care

Article 16. Comprehensive health care model. The enforcement authority shall design a model of specific and appropriate comprehensive health care to begin during pregnancy and last up to three (3) years of age, from the perspective of the right to comprehensive health of women, other pregnant people, and children, and taking into account the particularities of the territories in the entire country. The defined health care model must include the three (3) subsectors that make up the health system and coordinate with other relevant administrative agencies in the matter.

Article 17. Staff training. The professional personnel teams involved in the implementation of this law must be duly trained in its contents, guiding principles, and objectives as well as in the other normative provisions that regulate the matter, so they have adequate information and can develop the necessary skills to effectively comply with the provisions of this law. The enforcement authority will have a specific training program according to the different levels of attention of the different State organisms involved in its implementation.

Article 18. Community teams. The enforcement authority shall coordinate with the provinces and with the Autonomous City of Buenos Aires, within the framework of the existing work by community health care teams, in order to promote access for women and other pregnant persons and for children up to three (3) years of age to the relevant health services, to child development centers regulated by Law 26,233, to maternity and kindergartens regulated by Law 26.206, to the management of the procedures and documentation necessary, to reporting offices for cases of gender-based violence, to social assistance, and to corresponding social security benefits. To this end, the enforcement authority shall establish basic guidelines for intervention, articulation, and coordination of community health care teams and devices with the administrative bodies for the protection of rights established in Article 42 of Law 26,061, as well as with the competent national, provincial, or municipal administrative bodies.

Article 19. Training and participation. The enforcement authority shall publicly articulate and coordinate with primary health care centers; child development centers regulated by Law 26,233; kindergartens regulated by Law 26,206; to provide workshops and training spaces, participation and access to information for women and other pregnant people and their families, on comprehensive health care, early development and bonds, healthy eating, breastfeeding and violence prevention, among other relevant aspects from the perspective of the right to comprehensive health. 
The enforcement authority will promote the inclusion of the coresponsible parent during the prenatal consultation, creating a specific consultation to facilitate that person's preparation for the moment of childbirth and parenting.

Article 20. Public provision of basic supplies. The State shall implement the public and free provision of essential supplies for women and other pregnant persons during pregnancy and for children up to three (3) years of age, under the conditions determined by the relevant regulations.

In particular, it will provide:

a. Essential drugs;

b. Vaccines;

c. Milk;

d. Food for healthy growth and development in pregnancy and childhood, within the framework of the programs available for that purpose.

Article 21. Specific strategies for perinatal health and first years of life. The enforcement authority shall implement specific policies for the care, promotion, protection, and prevention for the comprehensive health of the pregnant people and children up to three (3) years of age. In particular, the Health System should promote:

a. Access to care for women and other pregnant people, with the aim of carrying out timely and comprehensive controls and interventions for the prevention, diagnosis, and treatment of any complications;

b. Safe sleep protection strategies for all children including training for health care teams, women and other pregnant people, and their families on practices that will prevent serious incidents during sleep;

c. Unintentional injury prevention strategies during the early years, which should include

training health care teams regarding the care of public and private spaces to prevent injuries

to children; the transmission of information to families about preventive measures; regulations on toy safety and furniture; and safe spaces for public and private transit; 
d. An efficient referral and counter-referral system between the first and second levels of health care;

e. In case of the hospitalization of children in public or private health care centers, that children have reciprocal contact with those who exercise the parental responsibility or guardianship according to the rules of the Civil and Commercial Code, as well as also with those relatives or people with whom they have an affective bond.

\section{CHAPTER V}

Right to protection in specific situations of vulnerability

Article 22. Organization of health care services for children in need of special care during their

early years. For children with more prevalent health conditions; a history of preterm delivery; congenital heart disease; other congenital malformations or genetic or metabolic diseases that imply a high risk or impact on health care and quality of life, the proper authority should organize a risk-care model prioritizing community-based interventions focused on families, within the framework of the primary health care strategy, with consequent co-responsibility for the most complex levels of health care.

The organization of these services should be gradually incorporated by health care providers, according to the deadlines established by the enforcement authority, and equipment for diagnostic procedures and techniques for high-pressure conditions with the highest prevalence in the early years should also be accompanied by training for those personnel using the equipment. Pregnant people should also have access to medical records of fetal morphology by ultrasound (or whatever method might replace ultrasounds it in the future) between 18 to 22 weeks of gestation, to identify and major congenital malformations or fetal health problems, as well as access to any other studies and practices that are established in the protocols promulgated by the enforcement authority.

Article 23. People with high-risk pregnancies. Thrombophilia. The enforcement authority must promote a health care model that prioritizes community interventions for comprehensive health care, equitable access to health care networks, perinatal health services organized according to the complexity required for diagnostic methods and the treatment procedures indicated, as well as ensuring that births occur in maternity hospitals that are safe for care, depending on the risk of the pregnant person or fetal health. 
For patients whom the treating professional suspects to have thrombophilia based on protocols established by the enforcement authority and on obstetric and non-obstetric antecedents, the enforcement authority must ensure access to free diagnostic studies and treatments for thrombophilia, both for people who rely exclusively on public coverage and for those who have other health care insurance. The enforcement authority should also promote the establishment of a health care model that prioritizes community interventions focused on comprehensive health care, with a focus on reducing risk and equitable access to health services according to the complexity required.

Article 24. Women or other pregnant persons in a situation of genderbased violence. The authority shall arbitrate the media so that, in the devices involved in the implementation of this law, women and other pregnant people are informed about their right to a life free of physical, psychological, obstetric, and institutional violence, and that they are provided with information on the available care devices and complaint procedures. To this end, the enforcement authority will design specific material to disseminate about this topic.

In those cases which, within the framework of health care, there are signs or suspicions of possible situations of gender-based violence, professional teams and intervening personnel have the duty to inform pregnant people about the rights established by Law 26,485 and about existing care and complaint resources. Pregnant people in situations of gender-based violence who express their willingness to be cared for by the mental health services should get care without delay. The health services must guarantee adequate care, coordinating with the competent bodies in the matter for the corresponding referral and in compliance with Law 26,485 .

Article 25. Indicators. The enforcement authority shall agree, within the framework of the coordination unit established in Article 30 of this law, on a list of comprehensive indicators that include the social determinants of health, so as to provide information at the population level with which it is possible to identify pregnant people and children in situations of threat or violation of rights that effect or could effect their overall health.

The enforcement authority will promote training about these indicators, a proactive search, and the protocols to be followed in cases of rights violations that effect comprehensive health, to all members of all health, social development, education, and child protection teams responsible for the comprehensive care of the health of pregnant people and children up to three (3) years of age. 
Article 26. Pregnant children and adolescents. The enforcement authority of this law shall ensure protocols for specialized care for pregnant children and adolescents under fifteen (15) years of age as a group in a highly vulnerable situation. Timely attention will be guaranteed from the health service for the detection of possible sexual abuse with all the necessary safeguards to preserve privacy and confidentiality and to respect progressive autonomy as established by the Civil and Commercial Code, avoiding revictimization.

\section{CHAPTER VI}

\section{Right to information}

Article 27. Comprehensive health care guide. The enforcement authority will design a comprehensive health care guide that will contain information specific to each stage of life, provide information on the right to a life free from violence, the benefits of breastfeeding, to stimulate coresponsibility in care tasks, highlighting early bonds, play, and enjoyment, and will publish that guide in an accessible format. The guide's dissemination will be promoted in all health care establishments, both public and private, that have obstetric and/or pediatric care, and through all possible means.

Article 28. Toll-free attention line. In coordination with the provinces and the Autonomous City of Buenos Aires and through the relevant government agencies, the enforcement authority must include in the already-existing toll-free telephone lines services and care for pregnant people and their families in order to provide adequate information according to the stage of gestation or early childhood age. The enforcement authority will develop content adaptable to various communication media and formats that promote and facilitate the access to information. A specific device will be created for the care, referral, and monitoring of women and pregnant people in situations of special vulnerability.

\section{CHAPTER VII}

Enforcement authority

Article 29. Enforcement authority. The National Ministry of Health is designated as the authority for the application of the present law. 
Article 30. Administrative coordination unit. This law creates an administrative coordination unit for the care and comprehensive health care of pregnant people during pregnancy and their children up to three (3) years within the scope of the National Ministry of Health. This unit will be tasked with taking a comprehensive approach and coordination of the actions necessary for the full implementation of what is established in the present law.

The administrative coordination unit will be made up of representatives:

a. Of the Ministry of Health of the Nation;

b. From the Ministry of Women, Gender, and Diversity;

c. From the Ministry of Social Development;

d. From the National Secretariat for Children, Adolescents, and the Family (SENAF);

e. From the Ministry of Education;

f. Of the National Administration of Social Security (ANSES);

g. From the National Registry of Persons (RENAPER);

h. Of the National Council for the Coordination of Social Policies;

i. Of other bodies that the enforcement authority considers relevant for the effective implementation of the present law.

Article 31. Functions of the administrative coordination unit. The unit created in Article 30 of this law will have the following responsibilities:

a. To guarantee the coordination of health, gender, food, care, transportation, and registration agencies, among others with competence in the matter;

b. Promote comprehensive care for women and other pregnant people and their children up to three (3) years;

c. Promote the efficiency and simplification of procedures and administrative management for the registration and obtaining of benefits, goods, and services, and the exercise of rights; 


\section{d. Encourage co-responsibility in the care of children;}

e. Guarantee the perspective of gender and respect for the human rights of women and other people pregnant women and children in the implementation of this law;

f. Guarantee access to information regarding the exercise of the rights contemplated in this law;

g. Design specific protocols for action from a rights perspective, including those referring to action in community settings for care during pregnancy and the first three (3) years of life, as well as specific protocols that will govern the operation of the hotline;

h. Design and implement technical advice and support tools, responsible referral devices, and

other governing mechanisms for personnel and agencies involved in the compliance with this law;

i. Prepare and execute a comprehensive training plan aimed at all personnel involved in the compliance of this law, ensuring that the content addresses the different issues and critical processes, which will be defined according to the different profiles that make up the teams of the areas involved.

Article 32. Unification of records and databases. The enforcement authority shall coordinate the means to promote the unification of registries and databases among the agencies involved in the implementation of this law in order to improve the effectiveness and access to rights, benefits and services, and will comply with an adequate follow-up and monitoring of policies.

Article 33. Monitoring and evaluation. The enforcement authority shall develop and implement a system for monitoring and evaluating this law's implementation, including the creation of indicators that will allow for evaluation of the access and the effective exercise of the rights guaranteed by the present law. The monitoring and evaluation scheme will be implemented in a transversal manner by the three (3) subsectors that make up the health system-public, social works, and prepaid medicine-making it mandatory to send the information required by the enforcement authority.

Article 34. Rendering of accounts. The enforcement authority must send to the Honorable Congress of the Nation an annual report with a 
progress status and other indicators regarding the implementation of this law.

Article 35. Communication to the National Executive Power.

PROMULGATED IN THE SESSION ROOM OF THE ARGENTINE CONGRESS, IN BUENOS AIRES, ON THE THIRTIETH DAY OF THE MONTH OF DECEMBER OF THE YEAR TWO THOUSAND TWENTY.

REGISTERED UNDER NUMBER 27,611

CLAUDIA LEDESMA ABDALA DE ZAMORA - SERGIO MASSA - Marcelo Jorge Fuentes - Eduardo Cergnul

Publication date 01/15/2021

\section{APPENDIX III}

1926

1946

1983

1986

1986

1987

1988

formed

1973

1977

1977

1980

1989

1990

1991

1992

1994
Women's Civil Rights Law

Women gain the right to vote

End of military dictatorship

First National Women's Meeting

Decree 2274/86 repeals ban on fertility controls

Divorce becomes legal

The Commission for the Right to Abortion is

Roe v. Wade

The Madres start marching in the Plaza de Mayo

U.S. Congress passes Hyde Amendment

Harris v. McRae

Webster v. Reproductive Health Services

Hodgson v. Minnesota

Women's Quota Law

Planned Parenthood of SE Penn v. Casey

Constitutional reform

2002 National Program of Sexual Health and Responsible Procreation Law

2003 Green pañuelos make their first appearance at the National Meeting during a special 
assembly on abortion

2004 The Campaign for the Right to Legal, Safe, and Cost-free Abortion forms at the end of 19th Annual National Meeting of Women in Mendoza

2005 Pension laws increase benefits for retired housewives

2006 Ley de ESI, creating the National Program of Integral Sexual Education

2007

2008

2009

2010

2015

2017

2018

the first time

2019

2020

March

2020

2021
Gonzalez v. Carhart

First bill to legalize abortion introduced

2009 Law 26,485, Comprehensive rights for the protection against violence against women

The creation of a universal child benefit allowance Marriage equality law

First Ni Una Menos march

Parity Law

2018 Ley Micaela, creating requirements for public employees to take trainings in gender and violence against women

Congress debates the legalization of abortion for

2018 Ley Brisa, providing economic reparations to victims of domestic or gender violence

Alberto Fernández elected in December

COVID-19 pandemic shuts down Argentina in

IVE Law passes in December

Trans person quota law 